\title{
Jørgensen's polycystine radiolarian slide collection and new species
}

\author{
JANE K. DOLVEN ${ }^{1 *}$, KJELL R. BJØRKLUND ${ }^{2}$ \& TAKUYA ITAKI ${ }^{3}$ \\ ${ }^{1}$ Department of Geosciences, University of Oslo, PO Box 1047 Blindern, N-0316 Oslo, Norway \\ ${ }^{2}$ Natural History Museum, Department of Geology, University of Oslo, PO Box 1172 Blindern, N-0318 Oslo, Norway \\ ${ }^{3}$ Geological Survey of Japan, AIST, Marine Geology Research Group/Institute of Geology and Geoinformation, \\ Tsukuba Central 7, 1-1-1 Higashi, Tsukuba, Ibaraki 305-8567, Japan \\ *Corresponding author (e-mail: jane@radiolaria.org)
}

\begin{abstract}
E. H. Jørgensen's radiolarian collection is stored at the Natural History Museum in Oslo and holds 93 slides, of these 76 are with plankton from the western and northern coast off Norway. Jørgensen described 43 new polycystine radiolarian species from this material, but did not assign any types. In this present study we have re-examined the collection, registered and photographed all slides and radiolarian specimens, and designated lectotypes and paralectotypes for many of Jørgensen's species. J. Micropalaeontol. 33(1): 21-58, January 2014.
\end{abstract}

KEYWORDS: radiolaria, taxonomy, Jørgensen's collection, type species, original descriptions

\section{INTRODUCTION}

Eugen Honoratus Jørgensen (1862-1938) (Fig. 1) was a Norwegian lecturer and scientist. He worked most of his life as a researcher at the Bergen Museum on the west coast of Norway. His main interest was botany and he made strenuous efforts to map and collect flowers and plants everywhere he travelled in Norway and abroad. This work resulted in several floras and monographs, in particular on Norwegian Eyebright and Liverworts, for which (e.g. Jørgensen, 1934) he received the 'Fridtjof Nansen Award' in 1935. Although Jørgensen's lifelong passion was botany, he also did some impressive work on marine plankton. Of the latter, perhaps the most well known are the publications on dinoflagellates (Jørgensen, 1911) and radiolarians (Jørgensen, 1905). His steady work, especially within taxonomy, has become a valuable contribution to several different fields in biology, and is still being used and acknowledged today.

Jørgensen published three papers on radiolarians (Jørgensen, $1900,1905,1907)$ as well as contributing tables and data to others (e.g. Gran, 1902). In his papers of 1900 and 1905 he discussed more than 100 radiolarian species, including the description of 43 new species of polycystines (Table 1). Many of the descriptions are accompanied by Jørgensen's hand-made drawings (see plates in Jørgensen, 1900, 1905), the quality of which is very good. When examining Jørgensen's slide collection we could in many cases identify the depicted specimen from the drawings published in 1900 and 1905, and assign these to lectotypes. Jørgensen also marked many of his slides with species names, which helped us locate the specimens (essentially his types) from which he described the new species. In the present study we have evaluated all of Jørgensen's radiolarian slides, identified and photographed all radiolarian specimens that had a good orientation and showed the key morphological characteristics, and have assigned lectotypes and paralectotypes to most of Jørgensen's species (Pls 1-7). We have chosen to list the spumellarians and nassellarians alphabetically according to how Jørgensen named them, although this may not be the formally accepted name today. It has been questioned if some of Jørgensen's species are synonyms of forms previously established by Haeckel or others. We have therefore to the best of our knowledge tried to make comments on these species under their respective remarks and present what, in our opinion, is their correct taxonomic position (including common name).

\section{PLANKTON SAMPLES AND SLIDES}

A large collection of plankton samples, from which Jørgensen made most of his slides, is stored at the University of Bergen. This collection is often referred to as Jørgensen's 'apotek' (apotek = pharmacy) and consists of a large number of small, labelled glass bottles with plankton material (Fig. 2a-d). These samples were collected during several research cruises off the west coast of Norway in 1897-1898 (see plankton tables in Jørgensen, 1900) and by Nordgaard and his crew during scientific cruises to the coast off northern Norway in 1899 and 1900 (see plankton tables in Jørgensen, 1905). Jørgensen's radiolarian slide collection, however, is stored at the Natural History Museum in Oslo. It holds two types of slides: the first type contains oxidized plankton including both radiolarians and other microorganisms; the second slide type holds one or more, well-preserved and clean, handpicked radiolarian specimens. The latter are in most cases identified to species level by Jørgensen himself (Fig. 2e, f). All specimens are preserved in either Canada balsam or Styrax-resin. Most are covered by thin circular cover slips ranging in diameter from $10-20 \mathrm{~mm}$, others by $20 \times 20 \mathrm{~mm}$ square cover slips. In a few slides tiny cracks can be observed in the outer resin margin due to drying. However, most slides are in very good condition. Jørgensen's radiolarian slides have been numbered from 1-76 and are shown in Pls 8-10. They are stored in their respective compartments in the slide box.

The purpose of this paper is to help the radiolarian community by improving access to Jørgensen's species concepts. As Jørgensen did not assign any holotypes, we have tried to assign lecto- and paralectotypes to as many of his species as possible. Jørgensen's two main papers, i.e. Jørgensen 1900 (in German) and 1905 (in English), were printed in low numbers and his original articles are difficult to find in most libraries. We have therefore decided to repeat Jørgensen's original species descriptions, along with 7 plates showing both our own photographs and Jørgensen's original line drawings of the lecto- and paralectotypes that we have designated. Jørgensen's descriptions from 1900 are sometimes very short or incomplete. He therefore made additional remarks and/or updated them for these species in 1905. In cases where the English description is an elaboration of the German one we have included both. In other cases where we think that the English description is better 

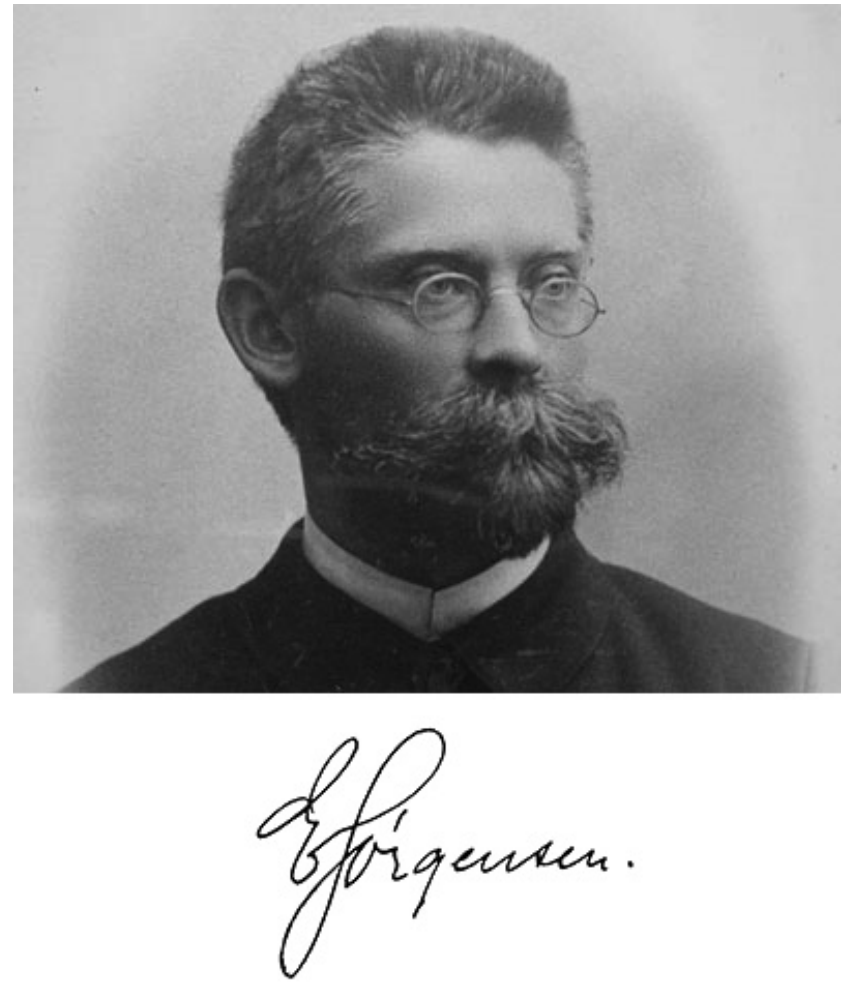

Fig. 1. Eugen Honoratus Jørgensen (1862-1938).

and more complete than the German one we have included only the former. This is done in an attempt to save space.

\section{JØRGENSEN'S RADIOLARIAN TAXONOMY}

Jørgensen was a great admirer of Haeckel's works on radiolarians, in particular Haeckel's extensive monographs from 1862 and 1887. 'Haeckel's splendid work on Radiolaria is on the whole admirable for its clearness and the ingeniousness with which apparently unimportant details are fitted together to make up a wonderful and consistently worked out system', Jørgensen wrote in 1905 (p. 122), and added: 'There may be differences of opinion as to the justification and appropriateness of the genera and families erected by Haeckel; it is impossible, however, not to admire the immense amount of valuable observations which are so plainly and clearly set forth in this extensive work' (p. 122). Jørgensen adopted most of Haeckel's spumellarian taxonomy, but as far as the nassellarian taxonomy was concerned he was more doubtful. Jørgensen disagreed with Haeckel's system that three elements (i.e. the 'basal tripodium', the 'sagittal ring' and the 'cephalis') were unique for the nassellarian classification and that either one (or more) of these could constitute the nassellarian skeleton. Jørgensen believed that Haeckel underestimated the importance of the 'basal tripodium'. He therefore redefined the 'basal tripodium' and stated that this - and this alone - was the common character (element) to all nassellarians (Jørgensen, 1905). His system was later discussed, supplemented and revised by Popofsky (1913) and Petrushevskaya $(1968,1971)$.

\section{JØRGENSEN'S NEW SPECIES OF POLYCYSTINE RADIOLARIANS}

Note that in this paper we include only the polycystine radiolarians (not acantharians and phaeodarians). We have listed the spumellarians and nassellarians alphabetically according to how Jørgensen named them. The present taxonomic position of each species is discussed under the Remarks.

\section{Spumellarians}

Acanthosphaera teneriformis Jørgensen, 1900

(No illustration)

1900 Acanthosphaera teneriformis Jørgensen: 54 (not figured).

\section{Original description (Jørgensen, 1900)}

Kugel dünnwandig, Maschen fast regelmässig 5- bis 6-eckig, wenig ungleich, 0,010 bis $0,016 \mathrm{~mm}$. breit, mit dünnen, gleichbreiten (nicht deutlich eckig verdickten), (0,001 bis $0,0015 \mathrm{~mm}$. breiten) Zwischenbalken. In allen Maschenecken feine, nadelförmige Nebenstacheln, ungefähr so lang wie der Radius $(0,037$ bis $0,045 \mathrm{~mm}$.). Durchmesser 0,081 bis $0,083 \mathrm{~mm}$. Sieht der Leptosphaera arachnoides sehr ähnlich, scheint aber der feinen arachnoidalen Hülle vollständig zu entbehren. Selten in Tiefseeproben: Juni - Oktbr., Decbr.

Types. Not defined

Remarks. Acanthosphaerida is, according to Haeckel (1887, p. 209) defined as 'one simple lattice-sphere, covered with simple radial spines of the same kind'. Jørgensen's Acanthosphaera teneriformis was described by the author only in 1900 and had no accompanying illustrations. According to Jørgensen, A. teneriformis looks very similar to Leptosphaera arachnoides although the former seems totally to lack the delicate, so-called arachnoidal (web like) shell that characterizes L. arachnoides. Unfortunately, we have not been able to find any specimens fitting this description in the Jørgensen radiolarian slide collection and, therefore, cannot draw any conclusions on the matter.

\section{Arachnosphaera dichotoma Jørgensen, 1900}

$$
\text { (Pl. 1, figs 1-4) }
$$

1900 Arachnosphaera dichotoma Jørgensen: 60-61; pl. 3, fig. 18.

\section{Original description (Jørgensen, 1900)}

Poren der Gitterkugel rundlich, 0,012 bis $0,015 \mathrm{~mm}$. breit, wegen hervorstehender, ziemlich dicker Wandungen hexagonal (selten pentagonal) umrahmt.Radialstacheln 15 (selten 14 bis 16), dreischneidig, ziemlich gleichbreit, gegen die Spitze verschmälert, am Grunde 0,003 bis $0,004 \mathrm{~mm}$. breit. Jeder Stachel trägt 1 bis 3 Wirtel von drei (selten vier) rechtwinklig abstehenden Seitenästen, deren jeder wiederholt gabelig verästelt ist. Die feinsten dieser Aestehen bilden mit einander eine zarte äussere Kugel. Es entstehen in dieser Weise 1 bis 3, mehr oder weniger unvollständige äussere Kugeln, von denen übrigens meistens nur die innere ziemlich vollständig ist. An jeder Schneide der Radialstacheln finden sich über den erwähnten Wirteln 1 bis 2 (selten 3) Wirtel rechtwinklig ausgesperrter Dorne, die einfach (oder die untersten ein wenig gabelig verästelt) sind und gegen die Spitze der Radialstacheln allmählich kürzer werden. Die (innerste, vollständige) Gitterkugel trägt in jeder Maschenecke einen sehr feinen, ziemlich langen Nebenstachel, der oben zweimal gabeltheilig ist. Bisweilen sind einige dieser Stacheln oben mit einander verbunden. Durchmesser der innersten Kugel 0,060 mm. Länge der Radialstacheln variabel, 0,100 bis $0,140 \mathrm{~mm}$. Diameter der zweiten (sehr oft unvollständigen) Gitterschale am häufigsten ungefähr $0,140 \mathrm{~mm}$., bisweilen kleiner. Mitunter findet man Individuen mit nur zwei Wirteln an jedem Radialstachel. Der obere besteht dann aus drei einfachen Dornen, der untere aus mehrmals gabeltheiligen Stacheln, die jedoch keine zusammenhängende Gitterschale bilden. Auch findet man (junge?) Individuen mit kürzeren Radialstacheln, die nur einen Wirtel von Aesten, die gabelig oder selten einfach sind, besitzen. Da aber in 
Jørgensen's polycystine radiolarian slide collection

Table 1. Jørgensen's new species of polycystine radiolarians including Jørgensen's original names, year of description, common name in 2011 (according to the authors) and comments.

\begin{tabular}{|c|c|c|c|c|c|c|c|}
\hline & Jørgensen's species name & 1900 & 1905 & LT & PT & $\begin{array}{l}\text { Regarded as correct name by } \\
\text { authors in } 2011\end{array}$ & Comment \\
\hline 1 & $\begin{array}{l}\text { Acanthosphaera teneriformis } \\
\text { Jørgensen, } 1900\end{array}$ & $\mathrm{x}$ & & no & no & ? & $\begin{array}{l}\text { Species not identified (same as Leptosphaera } \\
\text { arachnoides Jørgensen, 1900?) }\end{array}$ \\
\hline 2 & $\begin{array}{l}\text { Arachnosphaera dichotoma } \\
\text { Jørgensen, } 1900\end{array}$ & $\mathrm{x}$ & & 1 & 2 & $\begin{array}{l}\text { Arachnosphaera dichotoma } \\
\text { Jørgensen, } 1900\end{array}$ & \\
\hline 3 & $\begin{array}{l}\text { Drymyomma elegans } \\
\text { Jørgensen, } 1900\end{array}$ & $\mathrm{x}$ & $\mathrm{x}$ & 1 & 2 & $\begin{array}{l}\text { Drymyomma elegans } \\
\text { Jørgensen, } 1900\end{array}$ & \\
\hline 4 & $\begin{array}{l}\text { Echinomma leptodermum } \\
\text { Jørgensen, } 1900\end{array}$ & $\mathrm{x}$ & $\mathrm{x}$ & 1 & 1 & $\begin{array}{l}\text { Actinomma leptodermum } \\
\text { Jørgensen, } 1900\end{array}$ & Revised by Bjørklund (1976) to Actinomma leptodermum \\
\hline 5 & $\begin{array}{l}\text { Heliosphaera tenera } \\
\text { Jørgensen, } 1900\end{array}$ & $\mathrm{x}$ & & no & no & $?$ & Species not identified. \\
\hline 6 & $\begin{array}{l}\text { Hexacontium enthacanthum } \\
\text { Jørgensen, } 1900\end{array}$ & $\mathrm{x}$ & $\mathrm{x}$ & 1 & 1 & $\begin{array}{l}\text { Hexacontium enthacanthum } \\
\text { Jørgensen, } 1900\end{array}$ & $\begin{array}{l}\text { Includes Hexacontium enthacanthum forma heptacontia } \\
\text { Jørgensen, } 1900\end{array}$ \\
\hline 7 & $\begin{array}{l}\text { Hexacontium macracanthum } \\
\text { Jørgensen, } 1900\end{array}$ & $\mathrm{x}$ & & no & no & $?$ & Species not identified. \\
\hline 8 & $\begin{array}{l}\text { Hexacontium pachydermum } \\
\text { Jørgensen, } 1900\end{array}$ & $\mathrm{x}$ & $\mathrm{x}$ & 1 & 1 & $\begin{array}{l}\text { Hexacontium pachydermum } \\
\text { Jørgensen, } 1900\end{array}$ & $\begin{array}{l}\text { Includes Hexacontium pachydermum forma heptacontia } \\
\text { Jørgensen, } 1900\end{array}$ \\
\hline 9 & $\begin{array}{l}\text { Hexalonche diplacantha } \\
\text { Jørgensen, } 1900\end{array}$ & $\mathrm{x}$ & & no & no & $?$ & Species not identified. \\
\hline 10 & $\begin{array}{l}\text { Larcospira minor } \\
\text { (Jørgensen, 1900) }\end{array}$ & $\mathrm{x}$ & $\mathrm{x}$ & 1 & 3 & $\begin{array}{l}\text { Larcospira minor (Jørgensen, } \\
\text { 1900) }\end{array}$ & $\begin{array}{l}\text { Originally named Lithelius minor Jørgensen, 1900, } \\
\text { renamed Larcospira minor by Jørgensen (1905) }\end{array}$ \\
\hline 11 & $\begin{array}{l}\text { Leptosphaera arachnoides } \\
\text { Jørgensen, } 1900\end{array}$ & $\mathrm{x}$ & & no & no & $?$ & $\begin{array}{l}\text { Species not identified (same as Acanthosphaera } \\
\text { teneriformis Jørgensen, 1900?) }\end{array}$ \\
\hline 12 & $\begin{array}{l}\text { Streblacantha circumtexta } \\
\text { (Jørgensen, 1900) }\end{array}$ & $\mathrm{x}$ & $\mathrm{x}$ & 1 & 3 & $\begin{array}{l}\text { Streblacantha circumtexta } \\
\text { (Jørgensen, 1900) }\end{array}$ & $\begin{array}{l}\text { Same as Sorolarcus circumtextus Jørgensen, 1900, } \\
\text { renamed Streblacantha circumtexta by Jørgensen (1905) }\end{array}$ \\
\hline 13 & $\begin{array}{l}\text { Stylodictya aculeata } \\
\text { Jørgensen, } 1905\end{array}$ & & $\mathrm{x}$ & no & no & $?$ & $\begin{array}{l}\text { Species not identified. Probably same species as } S \text {. } \\
\text { validispina }=S \text {. stellata Bailey, } 1856\end{array}$ \\
\hline 14 & $\begin{array}{l}\text { Stylodictya aspera } \\
\text { Jørgensen, } 1900\end{array}$ & $\mathrm{x}$ & & no & no & $?$ & Species not identified. \\
\hline 15 & $\begin{array}{l}\text { Stylodictya tenuispina } \\
\text { Jørgensen, } 1905\end{array}$ & & $\mathrm{x}$ & 1 & no & $\begin{array}{l}\text { Stylodictya tenuispina } \\
\text { Jørgensen, } 1905\end{array}$ & \\
\hline 16 & $\begin{array}{l}\text { Stylodictya validispina } \\
\text { Jørgensen, } 1905\end{array}$ & & $\mathrm{x}$ & 1 & no & $\begin{array}{l}\text { Stylodictya stellata Bailey, } \\
1856\end{array}$ & See also Itaki \& Bjørklund (2006). \\
\hline 17 & $\begin{array}{l}\text { Tetrapyle polyacantha } \\
\text { Jørgensen, } 1900\end{array}$ & $\mathrm{x}$ & & no & no & $?$ & $\begin{array}{l}\text { Species not identified. Juvenile form of Phorticium } \\
\text { clevei? }\end{array}$ \\
\hline 18 & $\begin{array}{l}\text { Tetrapylonium clevei } \\
\text { Jørgensen, } 1900\end{array}$ & $\mathrm{x}$ & $\mathrm{x}$ & no & no & $\begin{array}{l}\text { Phorticium clevei (Jørgensen, } \\
\text { 1900) }\end{array}$ & \\
\hline 19 & $\begin{array}{l}\text { Androcyclas gamphonycha } \\
\text { (Jørgensen, 1905) }\end{array}$ & $\mathrm{x}$ & $\mathrm{x}$ & 1 & 5 & $\begin{array}{l}\text { Androcyclas gamphonycha } \\
\text { (Jørgensen, 1905) }\end{array}$ & $\begin{array}{l}\text { Same as } P \text {. theoconus, } P \text {. gamphonyxos and } P \text {. } \\
\text { amblycephalis Jørgensen, } 1900\end{array}$ \\
\hline 20 & $\begin{array}{l}\text { Campylacantha cladophora } \\
\text { Jørgensen, } 1905\end{array}$ & & $\mathrm{x}$ & 1 & 2 & $\begin{array}{l}\text { Neosemantis cladophora } \\
\text { (Jørgensen, 1905) }\end{array}$ & Revised by Goll (1979) to Neosemantis cladophora \\
\hline 21 & $\begin{array}{l}\text { Ceratospyris hyperborea } \\
\text { Jørgensen, } 1905\end{array}$ & & $\mathrm{x}$ & 1 & no & $\begin{array}{l}\text { Lophospyris pentagona } \\
\text { (Ehrenberg) hyperborea } \\
\text { (Jørgensen) }\end{array}$ & $\begin{array}{l}\text { Revised by Goll (1976) to Lophospyris pentagona } \\
\text { hyperborea }\end{array}$ \\
\hline 22 & $\begin{array}{l}\text { Cladoscenium limbatum } \\
\text { Jørgensen, } 1905\end{array}$ & & $\mathrm{x}$ & 1 & no & $\begin{array}{l}\text { Cladoscenium limbatum } \\
\text { Jørgensen, } 1905\end{array}$ & \\
\hline 23 & $\begin{array}{l}\text { Clathrocyclas craspedota } \\
\text { (Jørgensen, 1900) }\end{array}$ & $\mathrm{x}$ & $\mathrm{x}$ & 1 & 3 & $\begin{array}{l}\text { Corocalyptra craspedota } \\
\text { Jørgensen, } 1900\end{array}$ & $\begin{array}{l}\text { Originally named Theocalyptra craspedota Jørgensen, } \\
\text { 1900, revised Jørgensen (1905) to Clathrocyclas } \\
\text { craspedota. Changed to Corocalyptra craspedota by } \\
\text { Schröder (1914). }\end{array}$ \\
\hline 24 & $\begin{array}{l}\text { Dictyoceras acanthicum } \\
\text { Jørgensen, } 1900\end{array}$ & $\mathrm{x}$ & $\mathrm{x}$ & no & no & $?$ & $\begin{array}{l}\text { Species not identified. Probably a juvenile form of } \\
\text { Dictyoceras xiphephorum }\end{array}$ \\
\hline 25 & $\begin{array}{l}\text { Dictyoceras xiphephorum } \\
\text { Jørgensen, } 1900\end{array}$ & $\mathrm{x}$ & $\mathrm{x}$ & 1 & no & $\begin{array}{l}\text { Lipmanella irregularis } \\
\text { (Cleve, 1899) }\end{array}$ & $\begin{array}{l}\text { Same as Pterocorys irregularis (Bjørklund et al. 2014). } \\
\text { Latter species revised by Dumitrica (1973) to Lipmanella } \\
\text { irregularis (Cleve, 1899). }\end{array}$ \\
\hline 26 & $\begin{array}{l}\text { Dictyocircus clathrus } \\
\text { Jørgensen, } 1905\end{array}$ & & $\mathrm{x}$ & no & no & $\begin{array}{l}\text { Dictyocirus clathrus } \\
\text { Jørgensen, } 1905\end{array}$ & Species not identified. Juvenile form of Ceratospyris? \\
\hline
\end{tabular}


Table 1. (Continued)

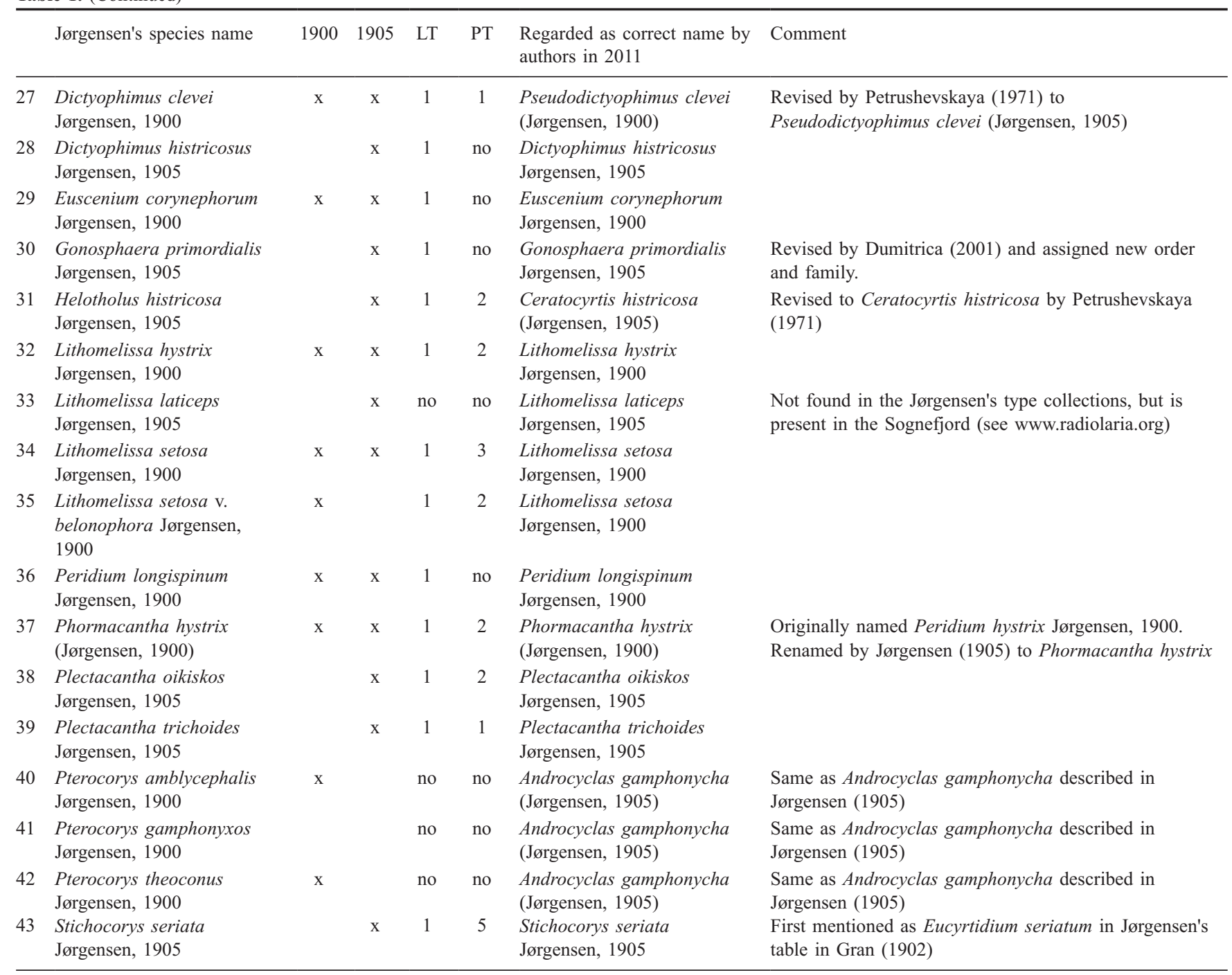

LT, lectotype; PT, paralectotype.

allen Fällen die innere Kugel mit den characteristischen Nebenstacheln dieselbe ist, habe ich in diesen abweichenden Formen nur dieselbe Art erblicken können. Nicht selten, immer spärlich vorkommend: April Juni, August - November.

Lectotype. PMO224.451; Plate 1, fig. 1; Slide \#1 (N35/0).

Paralectotype 1. PMO224.452/1; Plate 1, fig. 3; Slide \#73 (N37/1).

Paralectotype 2. PMO224.452/2; Plate 1, fig. 4: Slide \#73 (N37/2).

Remarks. In Norwegian waters young individuals of Cladococcus viminalis can be confused with young specimens of $A$. dichotoma. The latter species is characterized by its inner sphere diameter of about $60 \mu \mathrm{m}$, with 5-6 large polygonal pores ( 5 or 6 pore corners) across half the equator, and about 15 main radial spines, while $C$. viminalis has a diameter of about $80 \mu \mathrm{m}$, with about 8 or more rounded pores, but still indicating a polygonal outline, across half the equator. Radial spines, twice as long as the diameter, arise from each node (meeting point of three pores). Adult specimens cannot be misidentified, as A. dichotoma has 2 or 3 arachnoidal (web-like) spheres, while the outer $1 / 2$ to $1 / 3$ of the spines on $C$. viminalis fork like the branches on a tree giving the outer part of the skeleton a bushy appearance. It has been suggested that $A$. dichotoma is a synonym of one of Haeckel's species. We are of the opinion that the following characteristics cannot be met in any of the 6 Arachnosphaera species presented in Haeckel (1862, 1887): (1) diameter of the inner shell $60 \mu \mathrm{m}(62,62,65 \mu \mathrm{m}$, our measurements); (2) about 15 radial, triangular spines, from where up to 3 arachnoidal (web-like) spheres originate; (3) pores on inner shell between $12-15 \mu \mathrm{m}$ in diameter, irregularly round in outline with a hexagonal/pentagonal framing (pentagonal to insure the pores will define a regular inner shell). We therefore regard Arachnosphaera dichotoma Jørgensen as the correct formal name.

\section{Drymyomma elegans Jørgensen, 1900}

$$
\text { (P1. 1, figs 5-7) }
$$

1900 Drymyomma elegans Jørgensen: 58 (not figured). 1905 Drymyomma elegans Jørgensen, 1900; Jørgensen: 117; pl. 8, fig. 34 . 


\section{Description (Jørgensen, 1900)}

Drymyomma (n.gen): 3 concentrische Gitter-Kugeln. Aeussere Kugel mit einfachen kräftigen, dreishneidigen Radialstacheln sammt baumartig 2-bis 4-theiligen kürzeren Nebenstacheln.

Weich von der Gattung Pityomma durch einfache Hauptstacheln ab.

\section{Description (Jørgensen, 1905)}

This species, when fully developed, is very easily recognized by its branched byspines on the outside shell. The outside shell is strongly developed, thick walled, diameter $\pm 85 \mu$. The pores are roundish with broad intermediate walls, unevenly developed, though not so much so as in Chromyechinus borealis, on an average about the same size or perhaps most of them a little smaller. The two inner shells seem in all important respects to answer to those of the following species, Chromyechinus borealis. Still, I must call attention to the fact that I have had very little chance of examining them more thoroughly, as the species occurs so sparsely. The number of the main spines seems to vary (?) from about 15 up to about 20 . The largest are beautifully developed, long, slender and always branchless, a few of the smaller ones seem, on the contrary, occasionally to have a single needle shaped side branch, like the corresponding one in Chromyechinus borealis. Of byspines there are some resembling the main spines, only smaller and especially narrower. From these 3-edged spines there seems to be every transition to numerous narrow needle shaped ones without distinct edges. Most of the byspines, especially the narrow ones, carry in their upper halves from 1-4 obliquely diverging narrow branches, some of these again carrying a similar, but shorter, side branch. There seems to be a regular transition from the more delicate radial spines to the more strongly developed, 3-edged and branchless, byspines. It is, however, as above mentioned, probably not quite certain that the previously mentioned Echinomma-forms with long, slender main spines and byspines, should all be included in this species. These forms occur, with us, much more frequently than the fully developed Drymyomma elegans. Rare and scarce, only found at a few places in 1899: Sea off Gaukværö, 19/1, 0-700m., Senjen, 21/1, 0-130m., the Vest Fiord, 1/2, 0-200m., Skroven, 4/2, 350-300m., the Tys Fiord I, 28/3, 0-700m.

Distribution: Very rare also on the west coast of Norway, only in deep water. Also known from the Norwegian Ocean off Söndmöre and from the Vest Fiord, Feb. 1901 (Cfr. Gran L. 70 [1902], p. 150-151).

Lectotype. PMO224.453; Plate 1, fig. 5a, b; Slide \#22 (L36/1). Plate 1, fig. 5c original drawing by Jørgensen (1905, pl. 8, fig. 34a)

Paralectotype 1. PMO224.454; Plate 1, fig. 6a, b; Slide \#58 (H36/4).

Paralectotype 2. PMO224.455; Plate 1, fig. 7a, b; Slide \#68 (M36/4).

Remarks. At a certain ontogenetic stage this species can be easily misidentified as Actinomma trinacrium or the three sphere stage of $A$. boreale. A. trinacrium has long three-bladed radial spines of unequal length in all directions, while $A$. boreale normally has an asymmetrical spine distribution with its longest spines gathered in one area. In addition, $A$. boreale has transverse protrusions, indicating the position of a fourth thin cortical sphere, sometimes with an incomplete fourth sphere in the area with long spines. Drymyomma elegans is recognized by its many needle-shaped and forking byspines. Drymyomma elegans Jørgensen is regarded as the correct formal name.

\section{Echinomma leptodermum Jørgensen, 1900} (P1. 2, figs 1-2)

1900 Echinomma leptodermum Jørgensen: 57 (not figured).

1905 Echinomma leptodermum Jørgensen, 1900; Jørgensen: 116; pl. 8, fig. $33 \mathrm{a}-\mathrm{c}$.

\section{Description (Jørgensen, 1905)}

This species is at once recognized by having more numerous and shorter radial spines, larger and more uneven pores on its outside shell, as well as by its irregular (deformed) middle shell. It is also in other respects very different from the two preceding species [Hexacontium enthacanthum, $H$. pachydermum].

The outer ball thin-walled (the walls broader than they are thick). The pores polygonally roundish oval, very uneven in size, $7-25 \mu$, with intermediate walls $(2-4 \mu$ broad), which are much broader towards the corners (lumen rounded off). The middle shell moderately thick (the intermediate walls being as thick as they are wide, about $11 / 2 \mu$ ), rather angular and irregular, a little larger than in Hexacontium enthacanthum; diameter about $40 \mu$. The pores somewhat uneven, roundish, 4-7 $\mu$. The intermediate walls solid, not particularly broader in the corners. It is difficult to see the inmost shell, which possesses solid beams (about equal in thickness to those of the middle shell), but rather few polygonal, mostly pentagonal or hexagonal pores, about $8 \mu$. The diameter of the inmost shell about $15 \mu$ (or a little more). About 15 main spines, about equally broad inside as outside of the outmost shell, not long. They seldom protrude farther than to a length equal to the distance between the two outer shells, often less, and vary in development. Between the two inner shells, the radial spines are very narrow and in fact hardly wider than the beams of the inmost shell. The byspines on the outside shell are in appearance like the main spines, but not radially lengthened inwards, with a wide base on the outer shell (like the main spines) and very unevenly developed in size, although generally protruding less than the main spines. Variable in number; although, as a rule, not many, far from being developed in all the corners, only here and there. The number of the main spines is variable often only about 10 , though oftenest about 15 . They are 3-edged as in Hexacontium pachydermum. The nearest relation to this species is, without doubt, E. trinacrium Hck., which species, however, to judge from Haeckel's illustration and description (L. 84 [1862], p. 441, pl. 24 , f. $6-8$ ) is well distinguished by the construction of the inside ball, as well as by several other, less important, characteristics (as the number of the pores and spines). As in Hexacontium pachydermum and H. enthacanthum, there are forms without outer shells, but there is generally a trace of these in transverse processus on the main spines. These may, however, also be entirely absent. Such forms, of which one is illustrated on pl. VIII f. 33c, might equally well be reckoned as belonging to the genus Actinomma (without byspines on the third shell), respectively Haliomma (with only two shells), if their dimensions and other characteristics were not completely corresponding to the above species. Cfr. Jörgensen 1. c. p. 58. This species also varies a good deal. When the outside shell is thin-walled, the pores and intermediate walls are of a more uneven size. The byspines are in such cases slightly developed or (as yet) wanting. It is likely that these divergences may be accounted for by a difference in age. A more important difference is the number of main spines, which seems to be able to vary from 10 to 16. Comparatively frequent, though, like all radiolarian with us, always present in small numbers. It occurs, however, decidedly more frequently and in larger numbers than the two Hexacontium species.

Distribution: The same as that of Hexacontium enthacanthum and $H$. pachydermum. Frequent also on the west coast of Norway and in the Norwegian Sea.

Lectotype. PMO224.456; Plate 2, fig. 1a, b; Slide \#18 (N39/4). Plate 2, fig. 1c original drawing by Jørgensen (1905, pl. 8, fig. 33a).

Paralectotype. PMO224.457; Plate 2, fig. 2a, b; Slide \#19 (O38/1).

Remarks. The genus name Echinomma was synonymized by Bjørklund (1976) to Actinomma. Actinomma leptodermum is one of the most common species in Norwegian waters and can, in some cases, be difficult to separate from the three-sphere stage of A. boreale. However, when you are familiar with these two species, you will in most cases be able to discriminate between the two. Normally this can be done on the number of radial spines, $A$. 
J. K. Dolven et al.
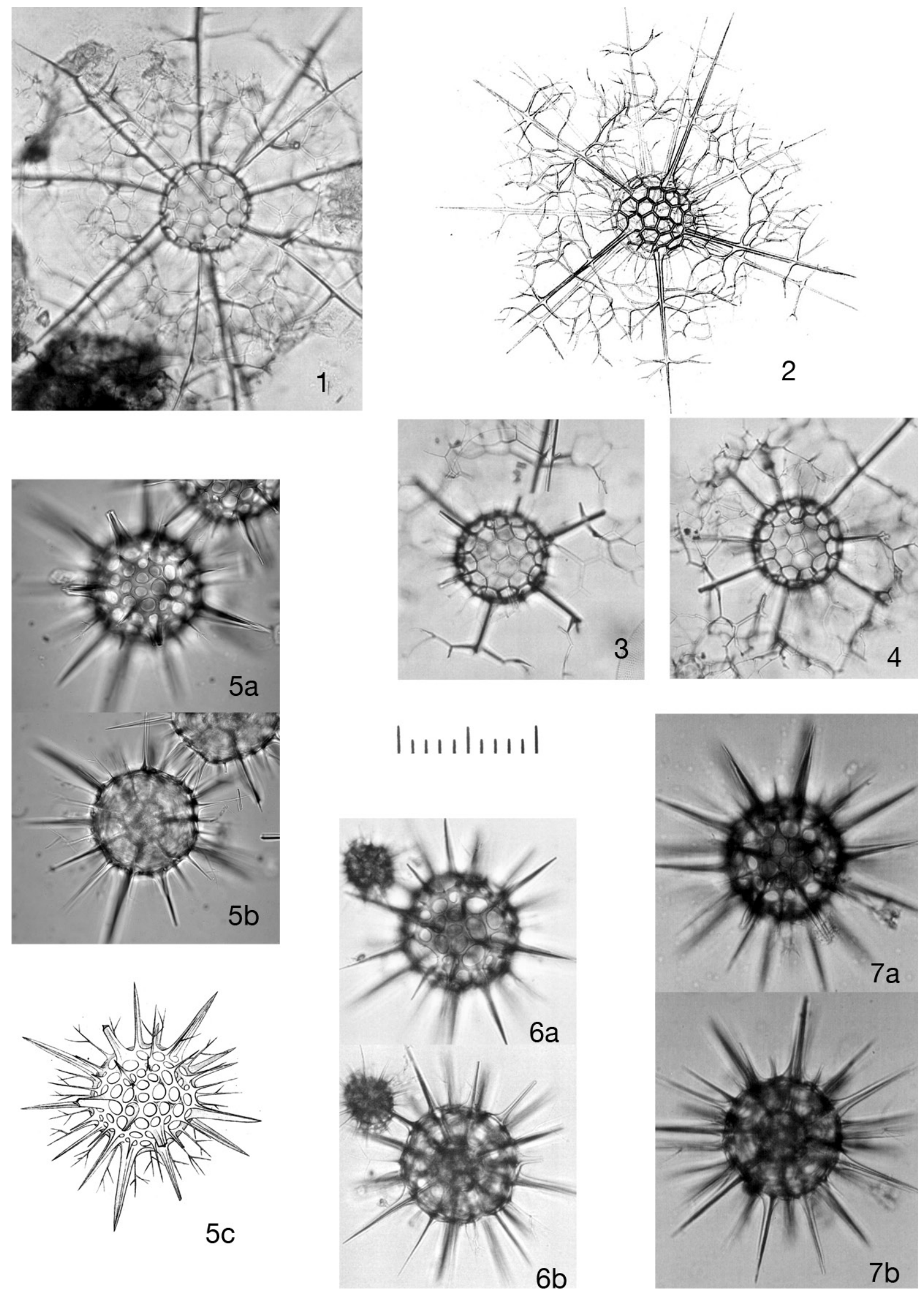
boreale having 20 or more, while A. leptodermum has 10 (8-15). Sometimes, when $A$. boreale has few spines and $A$. leptodermum has spines in its upper range they are hard to separate, but in most cases $A$. leptodermum shows a more open skeletal structure. Actinomma trinacrium and Drymyomma elegans, however, at their adult stages are easy to separate from the two principal species (i.e. A. leptodemum and A. boreale). However, it is not possible to separate the two-sphere juvenile stages of this suite of species.

Boltovskoy et al. (2010) mention that this morphotype is poorly defined and probably includes several species, including juvenile or partially dissolved 3-shelled stages of Chromyechinus antarctica (Haeckel). However, all actinommids in the Norwegian Sea have a rather similar structure for the three inner spheres, as well as for the structure of the radial byspines (needles). We are of the opinion that Actinomma leptodermum (Jørgensen) is a valid species and definitely differs from the 3-shelled stages of Chromyechinus antarctica (Haeckel). Actinomma leptodermum (Jørgensen, 1900) is regarded as the correct formal name.

\section{Heliosphaera tenera Jørgensen, 1900}

$$
\text { (No illustration) }
$$

\section{Heliosphaera tenera Jørgensen: 55 (not figured).}

\section{Description (Jørgensen, 1900)}

Schale einfach, zart. Maschen fast regelmässig 6-eckig (einige 5-eckige untermischt), gross, 0,011 bis $0,015 \mathrm{~mm}$. breit. Radialstacheln (ungefähr) 16, schmal, nadelförmig, etwa so lang oder etwas länger als der Radius. Nebenstacheln fein, ungefähr so lang wie die Breite einer Masche $(0,012-$ 0,015 mm.), leicht hinfällig. Durchmesser der Kugel 0,060-0,065 mm. Die Länge der Radialstacheln scheint ziemlich variabel zu sein. Ich habe mehrmals Individuen gefunden, die keine Nebenstacheln aufwiesen, also zur Gattung Acanthosphaera im HÄCKEL'schen Sinne gestellt werden sollten. Da aber die Stacheln sehr leicht abbrechen, habe ich nicht diese Formen von der sonst ähnlichen, oben beschriebenen, trennen dürfen. Sehr selten: Hjeltefjord, 5/2 1898.

Types. Not defined

Remarks. This species is described only in Jørgensen (1900) without illustrations. In the Jørgensen slide collections examined we have seen no heliosphaerid specimens fitting this description and can therefore not evaluate the species.

Hexacontium enthacanthum Jørgensen, 1900

$$
\text { (Pl. 2, figs 3-4) }
$$

1900 Hexacontium enthacanthum Jørgensen: 52; pl. 2, fig. 14. 1905 Hexacontium enthacanthum Jørgensen, 1900; Jørgensen: 115; pl. 8, fig. 30a, b.

\section{Description (Jørgensen, 1900)}

Die äussere Kugel dünnwandig, mit hexagonal-rundlichen, etwas ungleich grossen Maschen $(0,006$ bis $0,010 \mathrm{~mm}$. breit), ungefähr 5 auf dem
Quadrante. Breite der Zwischenwände ungleich, 0.001 bis $0,002 \mathrm{~mm}$. Keine Nebenstacheln. Die zweite Kugel mehr dickwandig, mit ähnlichen Maschen wie an der äusseren, nur kleiner $(0,004$ bis $0,006 \mathrm{~mm}$. breit), 5 bis 6 auf dem Qnadrante. Breite der Zwischenwände ungefähr 0,0015 mm. Feine, nadelförmige Nebenstacheln in allen Maschenecken, 1/3 bis 1/2 der Länge des Radius. Die innerste Kugel von dünnen, nicht eckig verdickten Balken gebildet, mit grossen unregelmässigen und ungleichen, polygonalen Maschen $(0,008$ bis $0,010 \mathrm{~mm}$. breit). Breite der Zwischenwände fast konstant, $0,001 \mathrm{~mm}$. Die sechs Hauptstacheln breit, dreischneidig, spitzig, von der zweiten Kugel aus gleichbreit (die äussere Kugel durchbohrend), über die äussere Kugel gewöhnlich etwas länger als der Radius hervorragend. Durchmesser der äusseren Kugel 0,062 bis $0,078 \mathrm{~mm}$., der mittleren 0,032 bis 0,034 , der innersten ungefähr $0,017 \mathrm{~mm}$. Man findet nicht selten Exemplare, denen die äussere Kugel gänzlich fehlt. In solchen Fällen sieht man aber noch an den Schneiden (ungefähr in der Mitte) scheinbar gebogene quergestellte Dornen, die die weggefallene äussere Kugel angeben. (Vergleiche T. II, F. 14, wo auch zwei der Hauptstacheln unsichtbar sind). Diese kleine Art (kleiner als die früher bekannten derselben Gattung) scheint durch die inneren Nebenstacheln, die zarte äussere und die wenig entwickelte innerste Kugel sehr ausgezeichnet zu sein.

Ziemlich häufig in tieferen Wasserschichten, immer aber mit wenigen Individuen vorkommend: Febr., April - Mai, Juli - Decbr.

\section{Description (Jørgensen, 1905)}

I will only add a few remarks to the detailed description given 1. c. (Jørgensen L. 91 [1900], p. 52). This species differs from the following [Hexacontium pachydermum] in having a delicate outer shell with comparatively narrow walls between the pores and no byspines. As in the following species $[H$. pachydermum], the pores on the outer shell are different in size, from $6-10 \mu$, most of them being $8 \mu$, although they are not strikingly unlike. The pores of the middle shell in both species are also alike, there is a slightly variation in the size of them on the same shell, they average $4-5 \mu$ (seldom as little as 3 or as much as 7 ). The pores on the two outer shells are about equal in number on the radius. But the innermost shell differs considerably in this respect, the pores here being comparatively much larger and consequently much fewer in number. On young specimens, where only the two inner shells are developed, one may often see transverse processus on the radial spines where the outer shell is found later on, these processus forming the intermediate walls of those pores in the outer shell which are situated nearest to the main spines. On still younger specimens, however, these processus are also wanting. Such forms (cfr. pl. 8, fig. 32) may easily be mistaken for species of the genus Hexalonche. If one considers the coincidence in dimensions and constructions of the inner shells of Hexacontium enthacanthum and $H$. pachydermum, it would, however, seem most reasonable to look upon them as being forms of these species. The outer shell varies in its development from very thin to moderately thick. The pores on the thicker shells seem to be rounder and to have wider walls, which are more plainly widened out in the corners. I have very rarely seen specimens with a trace of byspines (conically heightened parts) in the corners between the pores. These traces of byspines appear, however, to denote that the limit in the direction of $H$. pachydermum is not certain. The common name ought in this case to be $H$. pachydermum, which would then represent the

Explanation of Plate 1. fig. 1. Arachnosphaera dichotoma Jørgensen, 1900. Lectotype, PMO224.451, slide \#01 (N35/0). Herløfjorden 21 June 1898, 0-400 m. fig. 2. Arachnosphaera dichotoma Jørgensen, 1900. Original drawing of Jørgensen (1900, pl. 3, fig. 18). fig. 3. Arachnosphaera dichotoma Jørgensen, 1900. Paralectotype 1, PMO224.452/1, slide \#73 (N37/1). Herløfjorden February-December 1899, 0-400 m. fig. 4. Arachnosphaera dichotoma Jørgensen, 1900. Paralectotype 2, PMO224.452/2, slide \#73 (N37/2). Herløfjorden February-December 1899, 0-400 m. fig. 5. Drymyomma elegans Jørgensen, 1900. a, b, lectotype, PMO224.453, slide \#22 (L36/1), Senja 1899, 0-180 m; c, original drawing of Jørgensen (1905, pl. 8, fig. 34a, b). fig. 6. Drymyomma elegans Jørgensen, 1900: a, b, paralectotype 1, PMO224.454, slide \#58 (H36/4), Vesterålen 19 January 1899 , $0-700$ m. fig. 7. Drymyomma elegans Jørgensen, 1900: a, b, paralectotype 2, PMO224.455, slide \#68 (M36/4), Vesterålen 19 January 1899, 0-700 m. Note: where two or more images $(a, b,-)$ are not otherwise described they represent different focal planes. Scale bar $100 \mu \mathrm{m}$. 

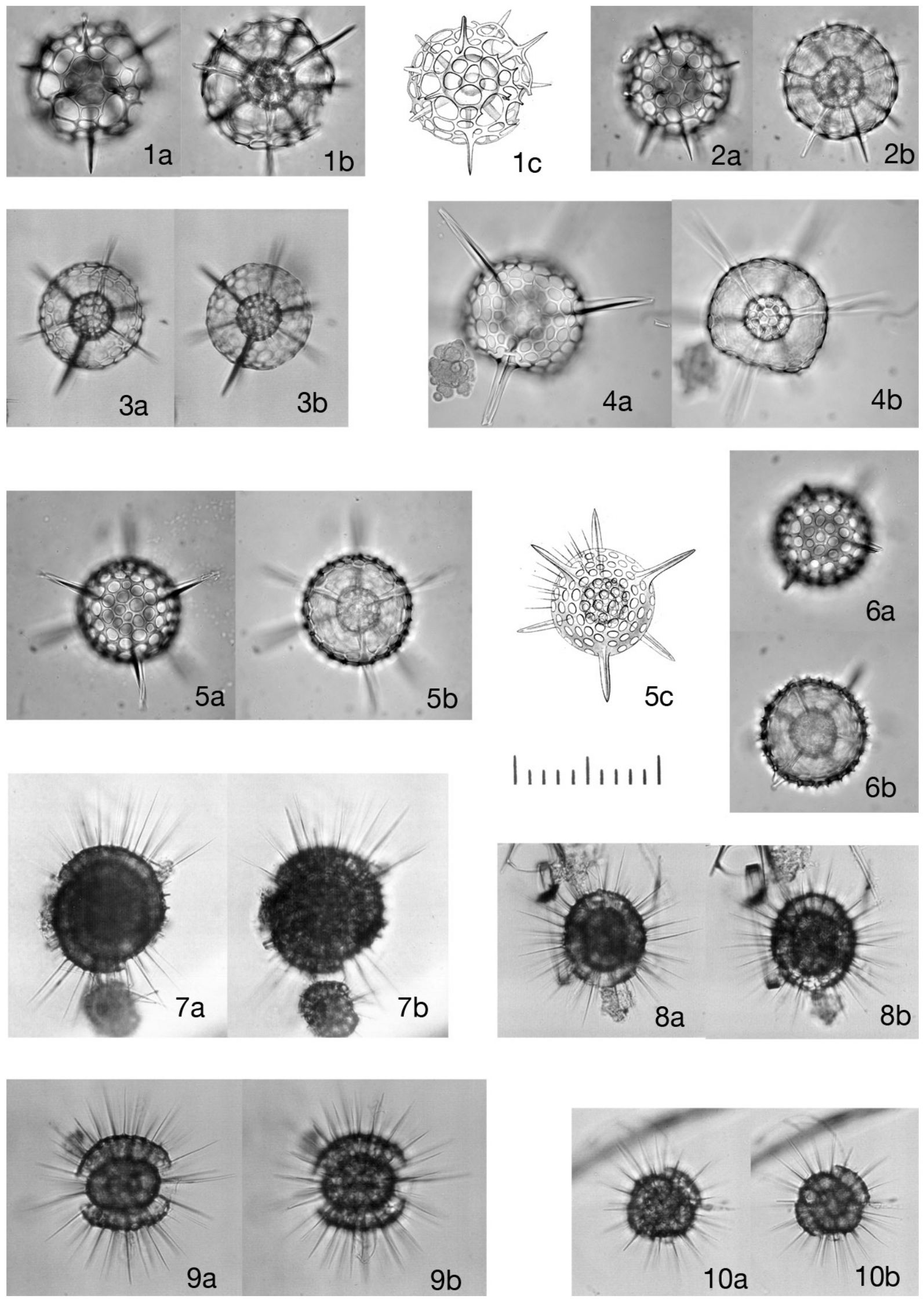
grown form. The number of the main spines is usually 6 , and sometimes 7 , but very seldom more. These are usually about equal in breadth inside as well as outside the outer ball. Ocean forms, of which I have seen a few, seem to diverge somewhat (both in this and the following species). The specimen illustrated pl. 8 , fig. 30 [H. enthacanthum] for instance, had a rather strong outer shell with main spines, which, as is the case with $H$. pachydermum, where considerably narrower inside the shell than outside. The inmost shell too was more solid than usual, and had comparatively more pores and with stronger walls (cfr. fig. 30b).

The dimensions of the outer and middle shells on 7 individuals (the 6 from the west coast of Norway):

$\begin{array}{llllllll}\text { Outer shell } & \text { wanting } & \text { wanting } & \text { wanting } & 62 \mu & 78 & 73 & 90 \\ \text { Inner shell } & 34 & 33 & 32 & 32 & 33 & 34 & 34\end{array}$

Thus it will be seen that the diameter of the middle shell varies remarkably little, while that of the outer varies considerably. Rare, in deep water samples, always in small numbers.

Distribution: Temperate oceanic form, which with us is only found in deep water, especially at a depth of $300 \mathrm{~m}$ or more. Somewhat more frequent on the west coast of Norway. Also known from scattered spots in the sea beyond the coast of Norway and from the Faeroe and Shetland Isles northwards.

Lectotype. PMO224.458; Plate 2, fig. 3; Slide \#73 (M38/3).

Paralectotype. PMO224.459; Plate 2, fig. 4; Slide \#32 (O36/4).

Remarks. Jørgensen (1900) described three species and two forms of the genus Hexacontium. However, in 1905 he was in great doubt about his previous taxonomic understanding of these species and was concerned that these were growth stages of one and the same species, e.g. that $H$. enthacanthum is a juvenile stage of $H$. pachydermum. In spite of this uncertainty he still treated them as two different species. Hexacontium enthacanthum is characterized by its delicate outer cortical (third) sphere, normally without any needle-shaped byspines. However, on the middle sphere there are numerous needle-shaped byspines, and it looks as if they are located with one on each node. It should be noted that it is easy to recognize juveniles, i.e. individuals with two spheres, of Hexacontium species from Actinomma species. It looks as if these juvenile stages of Hexacontium do not have numerous and welldeveloped byspines on the second sphere, which can be interpreted as these spines being mostly deposited at a later ontogenetic stage, supporting the idea of a centrifugal growth.

Jørgensen (1900, p. 52, pl. 4, fig. 20) also described a subspecies that he named $H$. enthacanthum forma heptacontia which has 7 spines instead of 6. However, Cortese \& Bjørklund (1998) observed that the number of spines was normally about 10 , but always $>8$, instead of the 6 main spines that are typical for Hexacontium. Both varieties of this species frequently co-occur. Hexacontium enthacanthum Jørgensen is regarded as the correct formal name.

Hexacontium macracanthum Jørgensen, 1900 (No illustration)

1900 Hexacontium macracanthum Jørgensen: 53-54 (not figured).

\section{Original description (Jørgensen, 1900)}

Die äussere Kugel (an dem gefundenen Exemplar sehr unvollständig) scheint wenige, sehr grosse, polygonale Maschen mit sehr kräftigen, fast gleichbreiten Balken zu besitzen. Diese Balken ( 0,003 bis $0,004 \mathrm{~mm}$. breit) waren mit zahlreichen, ausgesperrten Dornen versehen. (Länge eines dieser Balken 0,033 mm.). Durchmesser der äusseren Kugel 0,080 mm. Die zweite Kugel zart, mit unregelmässig rundlichen und polygonalen, ungleich grossen Maschen (0,004 bis $0,008 \mathrm{~mm}$.). Zwischenwände dünn, $0,001 \mathrm{~mm}$. breit oder etwas breiter, in den Ecken wenig verdickt. Feine, kurze Nebenstacheln in den Maschenecken, 0,004 bis 0,005 mm. lang, zerbrechlich. Durchmesser der zweiten Kugel 0,037 mm.

Die innerste Kugel wie bei Hexacontium enthacanthum mit dünnen Balken $(0,001 \mathrm{~mm}$.) und grossen polygonalen Maschen $(0,010 \mathrm{~mm}$.). Durchmesser $0,019 \mathrm{~mm}$. Radialstacheln (an dem beobachteten Exemplar) 7, sehr kräftig, ein wenig tordirt, $0,083 \mathrm{~mm}$. hervorragend, an der äusseren Kugel mehr als $0,020 \mathrm{~mm}$. breit, dreischneidig, allmählich lang zugespitzt, viel schmäler zwischen den beiden äusseren Kugeln. An den Schneiden dicht ausserhalb der äusseren Kugel finden sich ausgesperrte, feine, kurze Dornen, ähnlich denen an den Balken dieser Kugel. Diese schöne Art habe ich nur einmal gefunden: Herløfjord, 13/9 1898, in einer Tiefseeprobe (0-400 m.).

\section{Types. Not defined.}

Remarks. This species is described only in Jørgensen (1900) without any illustrations and he found it only once. In the Jørgensen slide collections examined we have seen no specimens of Cubosphaerida fitting this description. Jørgensen does not point out directly how it differs from $H$. pachydermum; however, it has been noted that the bars between the pores are furnished with several straight needle-shaped byspines, not only one on each node as in $H$. pachydermum. We have not observed this species in the Sognefjord plankton/sediments samples or in sediment material from the Nordic seas either. It is therefore not possible for us to evaluate if this is only an abnormal form of $H$. pachydermum.

\section{Hexacontium pachydermum Jørgensen, 1900}

$$
\text { (P1. 2, figs 5-6) }
$$

1900 Hexacontium pachydermum Jørgensen: 53 (not figured). 1905 Hexacontium pachydermum Jørgensen, 1900; Jørgensen: 115-116; pl. 8, fig. 31.

Explanation of Plate 2. fig. 1. Echinomma leptodermum Jørgensen, 1900: a, b, lectotype, PMO224.456, slide \#18 (N39/4), Kvænangen 24 January 1899, 0-140 m; c, original drawing of Jørgensen (1905, pl. 8, fig. 33a). fig. 2. Echinomma leptodermum Jørgensen, 1900: a, b, paralectotype, PMO224.457, slide \#19 (O38/1), Michael Sars Station nr. 12, 2 February 1901. fig. 3. Hexacontium enthacanthum Jørgensen, 1900: a, b, lectotype, PMO224.458, slide \#73 (M38/3), Herløfjorden February-December 1899, 0-400 m. fig. 4. Hexacontium enthacanthum Jørgensen, 1900. Paralectotype, PMO224.459, slide \#32 (O36/4), Kvænangen 24 January 1899, 0-140 m. fig. 5. Hexacontium pachydermum Jørgensen, 1900: a, b, lectotype, PMO224.460/1, slide \#38 (N37/0), Kvænangen 24 January 1899, 0-140 m; c, original drawing of Jørgensen (1905, pl. 8, fig. 31a). fig. 6. Hexacontium pachydermum Jørgensen, 1900: a, b, paralectotype, PMO224.460/2, slide \#38 (N37/0), Kvænangen 24 January 1899, 0-140 m. fig. 7. Larcospira minor (Jørgensen, 1900): a, b, lectotype, PMO224.461/1, slide \#58 (Q46/3), Vesterålen 19 January 1899, 0-700 m. fig. 8. Larcospira minor (Jørgensen, 1900): a, b, paralectotype 1, PMO224.461/2, \#slide 58 (N37/1), Vesterålen 19 January 1899, 0-700 m. fig. 9. Larcospira minor (Jørgensen, 1900): a, b, paralectotype 2, PMO224.462, \#slide 73 (M38/1), Herløfjorden February-December 1899, 0-400 m. fig. 10. Larcospira minor (Jørgensen, 1900): a, b, paralectotype 3, PMO224.461/3, \#slide 58 (O38/1), Vesterålen 19 January 1899, 0-700 m. Note: where two or more images (a, b, -) are not otherwise described they represent different focal planes. Scale bar $100 \mu \mathrm{m}$. 

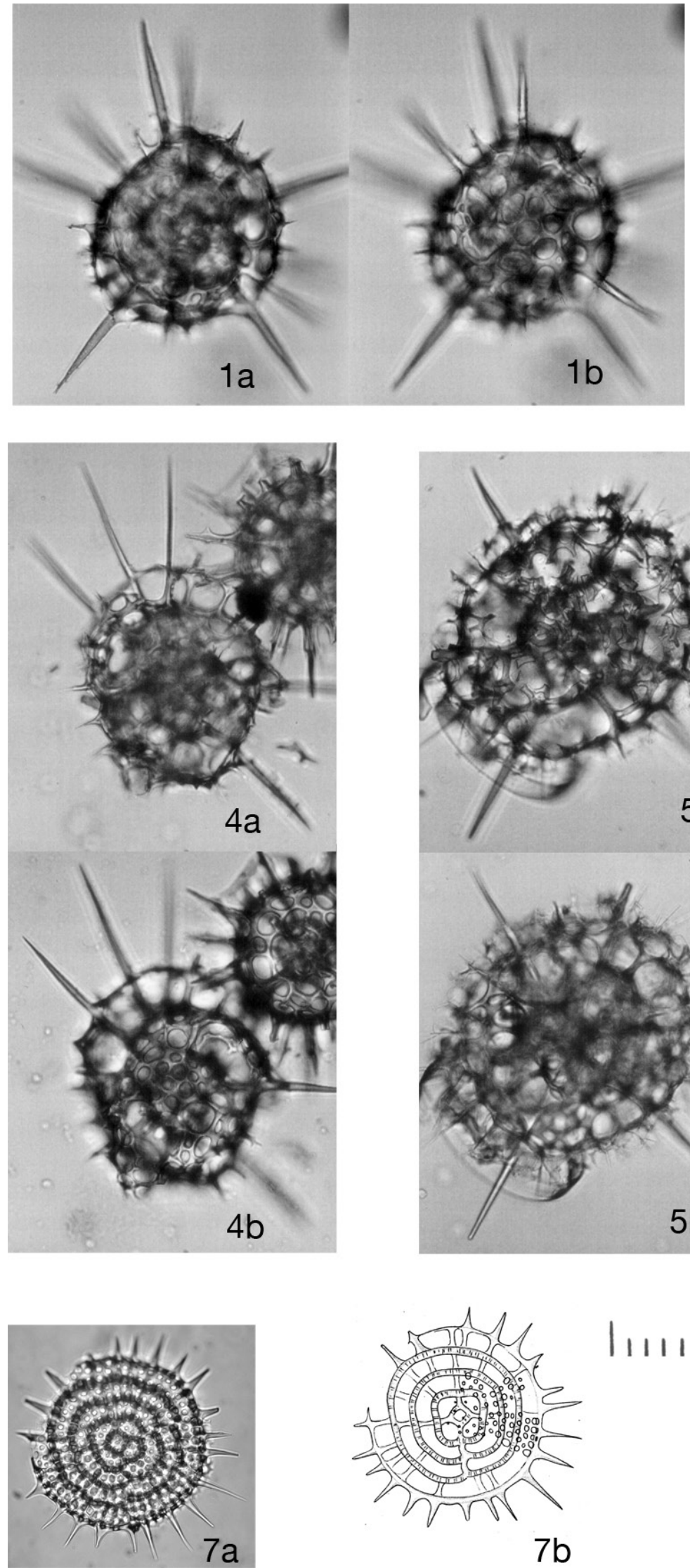
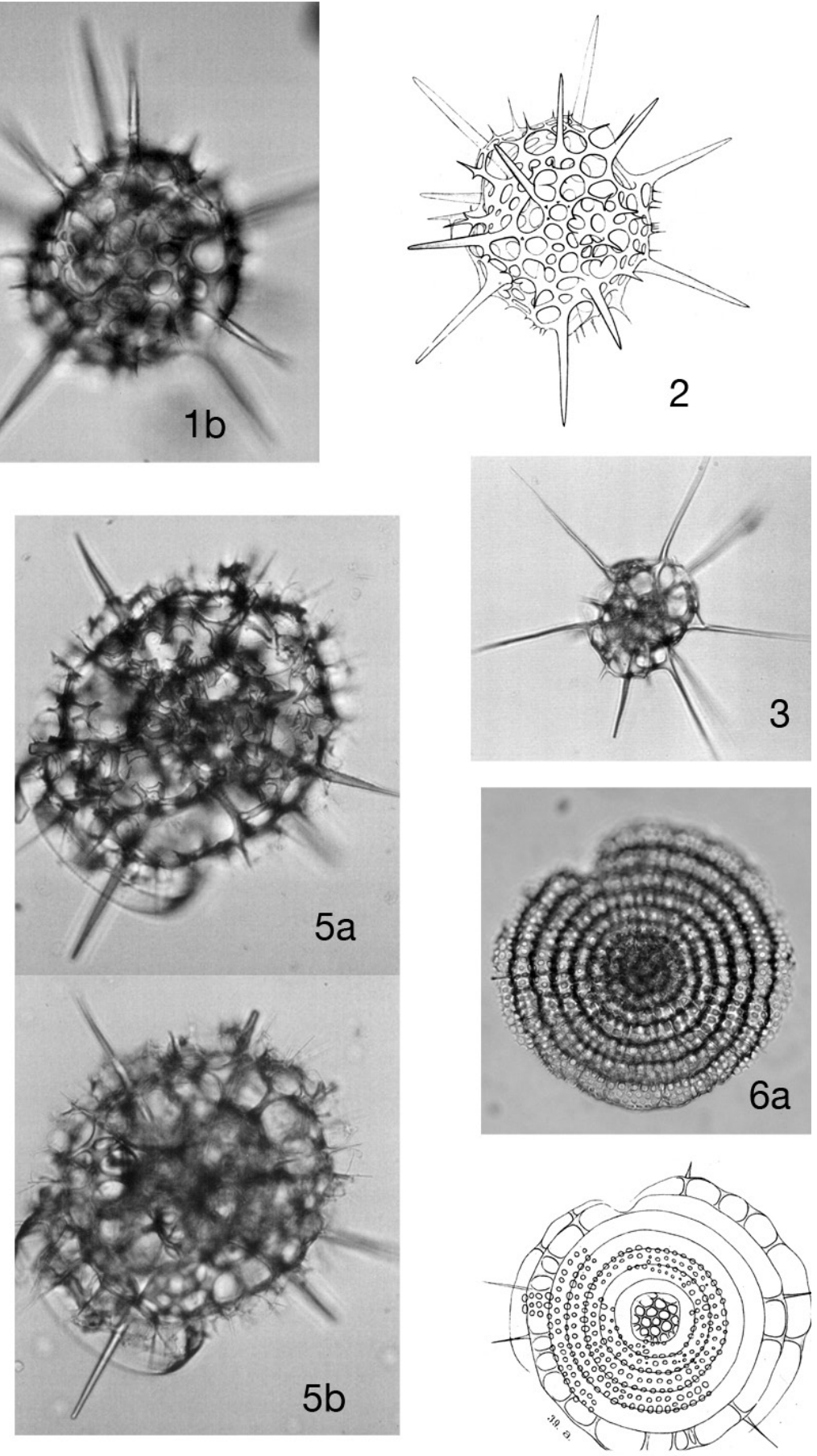

$6 \mathrm{~b}$
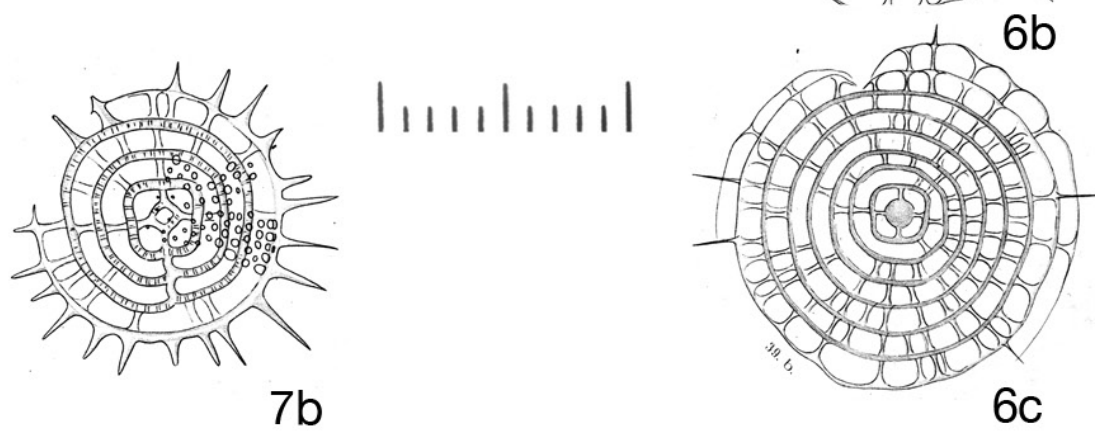


\section{Original description (Jørgensen, 1900)}

Die äussere Kugel sehr dickwandig, mit fast circulären, etwas ungleich grossen Maschen $(0,004$ bis $0,009 \mathrm{~mm}$. breit, die meisten jedoch $0.006-$ $0,007)$. Breite der Zwischenwände 0,002 bis $0,0025 \mathrm{~mm}$. Zahlreiche, ziemlich lange, leicht abfallende, nadelförmige Nebenstacheln, in den Ecken und an den Seiten der Maschen. Die zweite Kugel weniger dickwandig, mit eckigen bis rundlichen kleineren Maschen $(0,003$ bis $0,006 \mathrm{~mm}$.). Zwischenwände 0,0015 bis $0.002 \mathrm{~mm}$. breit. Aehnliche Nebenstacheln wie an der äusseren Kugel (hier meist schwer zu sehen), ungefähr $1 / 3$ des Radius $(0,010 \mathrm{~mm}$. lang). Die innerste Kugel wie an Hexacontium enthacanthum mit wenigen, grossen, polygonalen Maschen (bis $0,012 \mathrm{~mm}$.) und dünnen, nicht eckig verdickten, Zwischenbalken.

Die sechs Hauptstacheln wie an der vorhergehenden Art, gewöhnlich aber etwas kürzer, auch ein wenig schmäler zwischen den zwei äusseren Kugeln (als ausserhalb der äussersten). Durchmesser der äusseren Kugel 0.070 bis $0,075 \mathrm{~mm}$., der mittleren 0,032 bis 0,034 , der innersten ungefähr $0,017 \mathrm{~mm}$.

Diese Art sieht dem Hexacontium asteracanthion HCK. (L. 68 [1862], p. 441, T. 23, F. 5, 6), sehr ähnlich, weicht aber durch die sehr dickwandige äussere Kugel, die Nebenstacheln an der mittleren und die ganz abweichende innerste Kugel ab. Sie kann auch leicht mit Hexalonche diplacantha verwechselt werden. Wie die vorige Art in tieferen Wasserschiehten vorkommend, meistens in grösserer Individuenanzahl: Febr., Mai - Decbr.

\section{Description (Jørgensen, 1905)}

The byspines on the outer shell vary considerably in length. They are found in all corners where the pores meet, so that each pore is surrounded by several byspines (generally 5 or 6 ). The pores on the outer shell are more or less round, the intermediate walls being on the whole broader than in the preceding species [Hexacontium enthacanthum], answering to the development of the outer shell which is altogether stronger in this species. This shell is especially thick. The length of the main spines varies considerably. The byspines on the middle shell are little conspicuous, and may be easy overlooked (as in the case of the preceding species $[$ H. enthacanthum]). The innermost shell is here seen less clearly than in $H$. enthacanthum, unless the thicker outer shell be removed. One may, therefore, easily mistake this species for a Hexalonche, by overlooking the inside ball. I have, however, repeatedly convinced myself on breaking the outer shells, that it is always present. Its construction is the same as in the preceding species. No important difference in dimensions between this species and the preceding one seems to be found, and this is a very important factor when considering the question as to whether these supposed species are specifically different, or only constitute different forms of one of the same species. Here too the outer shell varies in size, but the middle and inmost ones are remarkably uniform in this respect and resemble those of $H$. enthacanthum. The ocean forms, however, appear to diverge essentially. I have not had an opportunity, though, of studying them more thoroughly in richer material, so that I cannot yet give a definite opinion as to the probability of separating new species. This, however, does not seem unlikely. For such a strongly developed ocean form from the sea beyond Söndmöre (in February 1901, S/S Michael Sars, a sample kindly given to me by Dr. Gran) was found. Strong, long main spines (most of them broken off). Numerous byspines (4-6 round each pore), long, needle shaped, $40 \mu$ long (nearly $4 / 5$ of the radius of the outer shell). Outer shell very thickwalled (6-7 $\mu$ thick), pores almost even, $\pm 8 \mu$, very broadwalled, round, a little broader than the walls. 7 main spines, much narrower between the outer shells than outside the outmost one. The diameter of the three balls $108,39,19 \mu$. Occurred like the preceding species rather rarely and sparsely in deep water samples, though perhaps somewhat more frequently. As a rule it is found in deep water samples from such outer places where the sea water has easy access. During the spring diatom inflow, it seem generally to be absent, except at greater depths in the inner fiords, where scattered specimens occur. This also seems to be the case, on the whole, with regard to the other Spumellaria. Distribution: Chiefly the same as in the preceding species [H. enthacanthum], often found together with it.

Lectotype. PMO224.460/1; Plate 2, fig. 5a, b; Slide \#38 (N37/0). Plate 2, fig. 5c original drawing by Jørgensen (1905, fig. 31a).

Paralectotype. PMO224.460/2; Plate 2, fig. 6a, b; Slide \#38 (N37/0).

Remarks. See also the remarks under Hexacontium enthacanthum. Jørgensen (1905, pp. 114-115) writes: 'These species, which I at first thought very different, agree so remarkably in some respects, that now I consider it by no means unlikely that $H$. enthacanthum is a young state of $H$. pachydermum. The points of agreement are chiefly in the second shell and in all probability also in the inner one, which is, however, more difficult to examine carefully, as it cannot be seen well unless the outer shells are removed. It is however difficult to obtain this without destroying the inner shell. The points of disagreement are in the outer ball and are so evident in most instances that it will hardly be recommendable, at any rate at present, to consider the two species as identical. The outermost shell does, nevertheless, appear to vary considerably, both in diameter, the thickness of its wall and its pores, while the middle one varies remarkably little. I have in exceptional cases found specimens of $H$. enthacanthum, where there were signs of byspines on the outermost shell (they are easily broken off), but have however, never met with any instance of doubt as to whether a given specimen was $H$. enthacanthum or $H$. pachydermum, when only the outer shell was present. Whether there may possibly be several species or not, I have not been able to decide, as both those above mentioned occur too rarely in my material. Yet, I have the impression that it is only a question of different forms, not of different species. When the outside shell is wanting - I look upon such forms as young specimens - I am, however, quite unable, at present, at any rate, to decide whether the specimen belongs to the one or the other of the species above mentioned. (Cfr. pl. VIII, f. 32, a, b)'.

Cortese \& Bjørklund (1998) described a new species Hexacontium gigantheum, based on plankton samples as well as skeletons extracted from sediment samples. This was done because the rich Hexacontium population in their material allowed them to undertake measurements and statistical analyses, which clearly showed that the $H$. gigantheum population did not overlap with the other Hexacontium species. In summary, four Hexacontium species are so far known from Norwegian waters:

\footnotetext{
Explanation of Plate 3. fig. 1. Streblacantha circumtexta (Jørgensen, 1900): a, b, lectotype, PMO224.463, slide \#52 (O37/2), Tysfjord 28 March 1899, 0-700 m. fig. 2. Streblacantha circumtexta (Jørgensen, 1900). Original drawing of Jørgensen (1900, pl. 11, fig. 46a). fig. 3. Streblacantha circumtexta (Jørgensen, 1900). Paralectotype 1, PMO224.464/1, slide \#65 (N36/2). Vestfjorden 13 January1899, 0-180m. fig. 4. Streblacantha circumtexta (Jørgensen, 1900): a, b, paralectotype 2, PMO224.464/2, \#slide 65 (N38/1). Vestfjorden 13 January 1899, 0-180 m. fig. 5. Streblacantha circumtexta (Jørgensen, 1900): a, b, paralectotype 3, PMO224.464/3, \#slide 65 (O37/0). Vestfjorden 13 January 1899, 0-180 m. fig. 6. Stylodictya tenuispina Jørgensen, 1900: a, lectotype, PMO224.465, slide \#54 (N37/0), Vesterålen 22 March 1899, 0-900 m; b, c, original drawings of Jørgensen (1900, pl. 10, fig. 39a and b) respectively. fig. 7. Stylodictya validispina Jørgensen, 1900: a, lectotype, PMO224.466, slide \#54 (M37/0), Vesterålen 22 March 1899, 0-900 m; b, original drawing of Jørgensen (1900, pl. 10, fig. 40a). Note: where two or more images (a, b, - ) are not otherwise described they represent different focal planes. Scale bar $100 \mu \mathrm{m}$.
} 
J. K. Dolven et al.
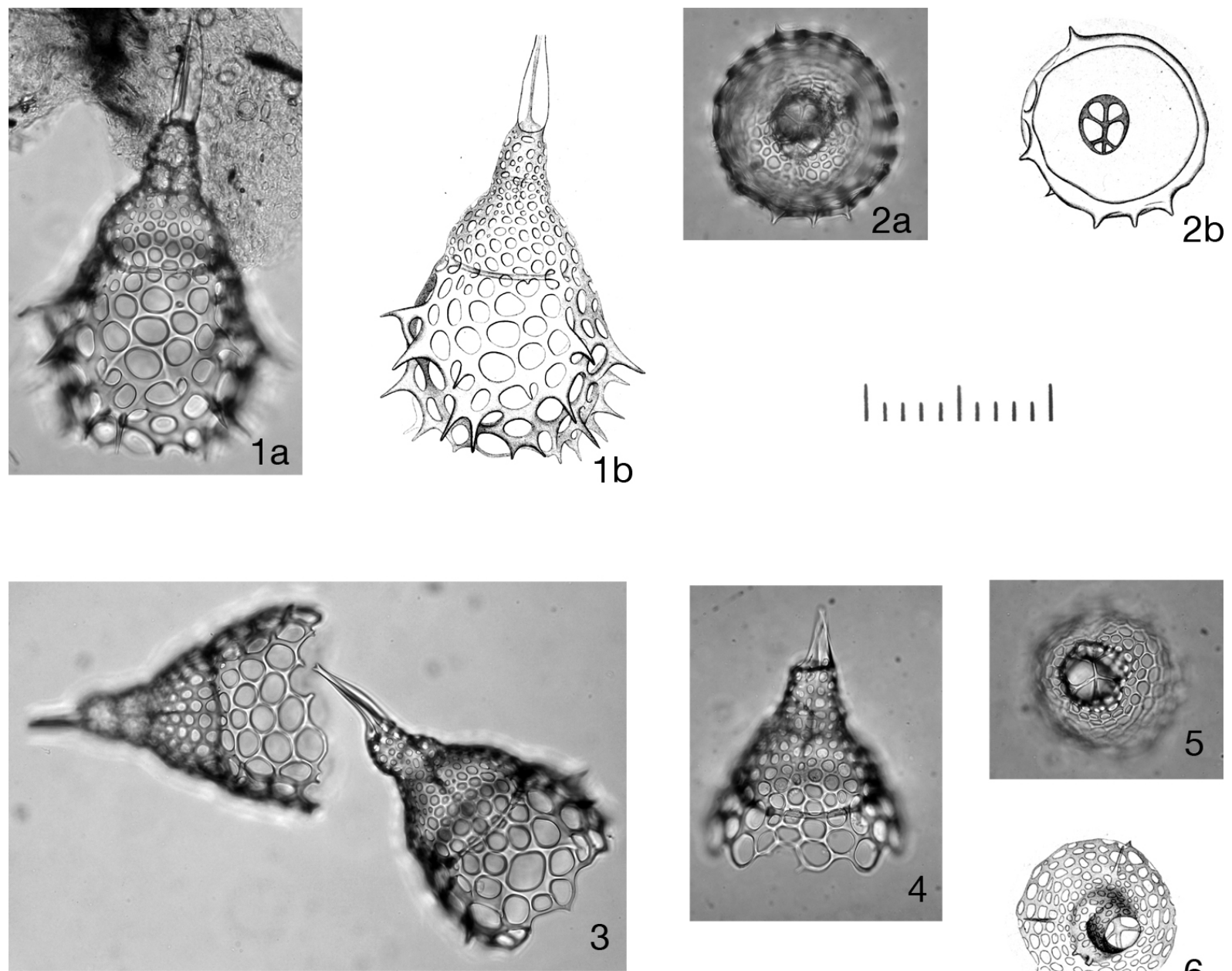

$|1111| 1111 \mid$

$1 \mathrm{~b}$
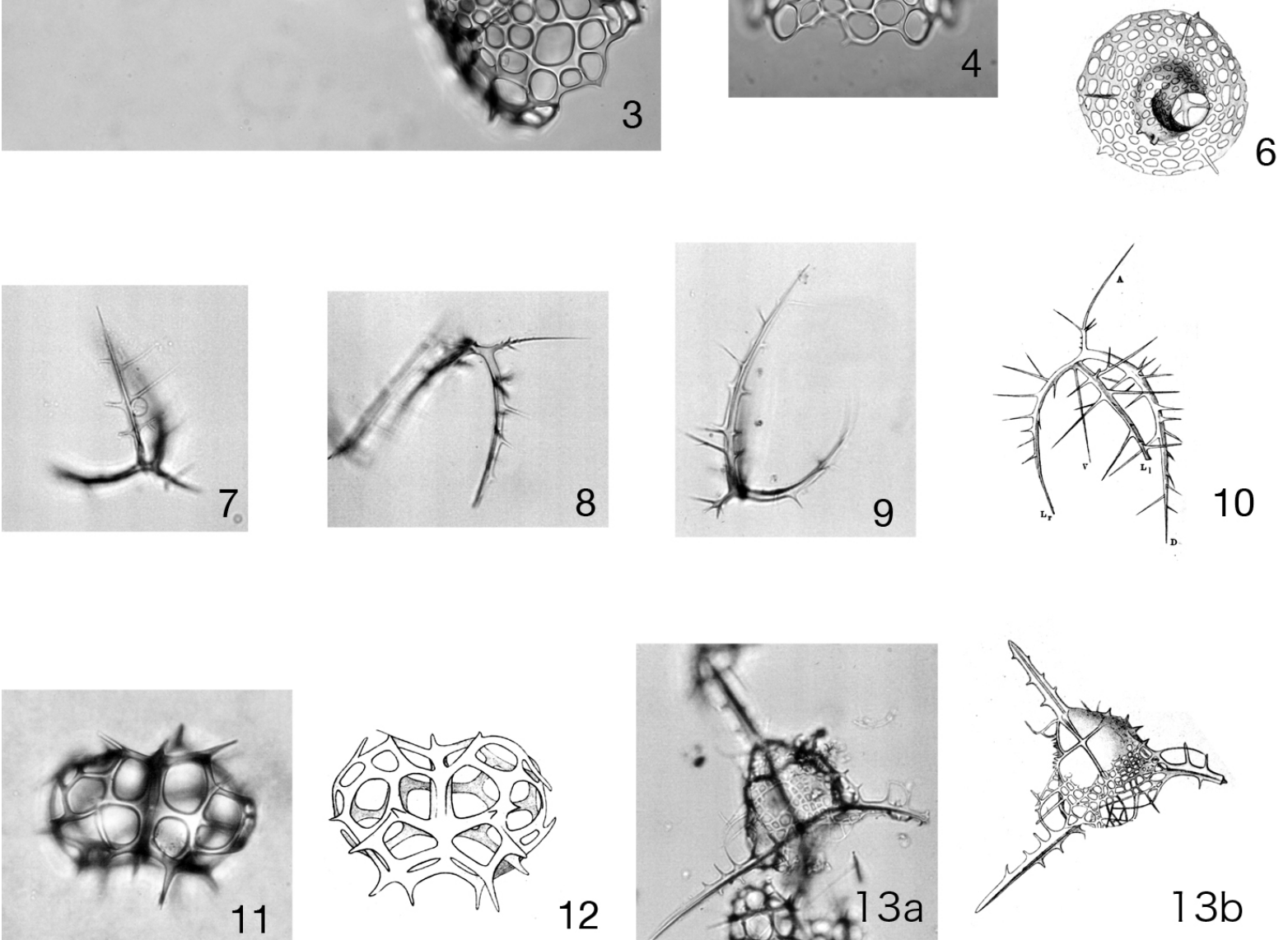

12
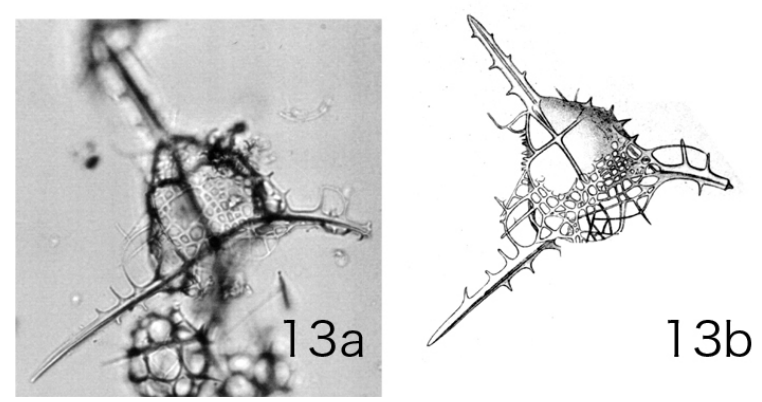
H. enthacanthum with a thin cortical sphere with no/few byspines and c. $80 \mu \mathrm{m}$ diameter; $H$. pachydermum with a thick cortical sphere with many byspines and $c$. $74 \mu \mathrm{m}$ diameter on average; $H$. gigantheum with a thick cortical sphere with many byspines and c. $97 \mu \mathrm{m}$ diameter on average; and H. hostile (the two latter species not figured herein) with a moderately thick cortical sphere with many byspines and a somewhat larger diameter of the third sphere (Cleve, 1900: $90 \mu \mathrm{m}$ ), having an outline that looks pyramidal around the six main radial spines. Boltovskoy et al. (2010) concluded that this is a very heterogeneous grouping where 5-10(?) species are included. Its troubled taxonomy needs more work to be sorted out. Hexacontium pachydermum Jørgensen is regarded as the correct formal name.

\section{Hexalonche diplacantha Jørgensen, 1900 (No illustration)}

1900 Hexalonche diplacantha Jørgensen: 51-52 (not figured).

\section{Original description (Jørgensen, 1900)}

Aeussere Kugel wie bei Hexacontium asteracanthion HCK. L. 68 [= HCK 1862; original citation incorrect], T. 23, F. 5, 6 mit etwas ungleich grossen rundlichen und länglichen Poren sammt zahlreichen nadelförmigen Nebenstacheln, ist aber dickwandig. Innere Kugel fast ganz wie die äussere, nur kleiner und mit verhältnissmässig längeren Nebenstacheln ( $2 / 3$ des Radius). Poren etwas ungleich, rundlich, 3 bis 4 auf dem Radius.

Diese Art sieht dem Hexacontium asteracanthion HCK. und dem H. pachydermum sehr ähnlich, weicht aber auffällig ab durch die einfache innere Kugel mit grossen Nebenstacheln.

Sehr selten; nur einmal gefunden: Herløfjord, 25/4 1898, in einer Tiefseeprobe. Vielleicht als eine Form des Hexacontium pachydermum mit fehlgeschlagener innerster Kugel anzusehen.

Types. Not defined.

Remarks. This species is described only in Jørgensen (1900) without illustrations. When we examined the Jørgensen slide collection we did not find any specimens fitting this description. Jørgensen states that this might just be a form of Hexacontium pachydermum that failed to develop the innermost sphere. Jørgensen compared his Hexalonche diplacantha with Hexacontium asteracanthion (Haeckel, 1860) and Hexacontium pachydermum. Haeckel's taxonomic handling of Hexacontium asteracanthion is also of interest. It was first described as Haliomma asteracanthion Haeckel (1860, p. 816; not figured), then as Actinomma asteracanthion (in Haeckel, 1862, p. 441, pl. 23, figs 5-6), before ending up as Hexacontium asteracanthion (in Haeckel, 1887, p. 196). Jørgensen's Hexacontium pachydermum $(70 \mu \mathrm{m})$ is different in size from Haeckel's Hexacontium asteracanthion $(100-120 \mu \mathrm{m})$. As Hexalonche diplacantha has been found only once (i.e. in Jørgensen, 1900), we are not able to verify its validity.

\section{Larcospira minor (Jørgensen, 1900) (P1. 2, figs 7-10)}

1900 Lithelius minor Jørgensen: 65-66; pl. 5, fig. 24.

1905 Larcospira minor (Jørgensen, 1900); Jørgensen: 121 (not figured).

\section{Original description (Jørgensen, 1900)}

Spirale doppelt; jede nur mit 1 1/2 Umgängen. Länge 0,065 mm., Breite 0,058 .

Markschale kaum $0,011 \mathrm{~mm}$. breit. Aeussere Poren etwas ungleich gross, rundlich bis oval, dickwandig. Ungefähr 150 lange, schmale Radialstacheln, die längsten ungefähr $0,030 \mathrm{~mm}$. (= d. Radius) oder mehr hervorragend. Diese kleine Art steht dem Lithelius solaris HCK. in allen Hinsichten sehr nahe, unterscheidet sich aber ausser durch die viel kleineren Dimensionen auch durch nur 1 1/2 (statt 4) Umgänge der Spiralen. Auch sind die Spiralgänge fast gleichbreit, nur wenig breiter nach aussen. Nicht selten, immer spärlich vorkommend: Mai-September, November.

\section{Original description (Jørgensen, 1905)}

This species has a very different appearance, according to the position in which it is seen. In one position it has an appearance corresponding to the illustration referred to, and which caused me to consider it as a Lithelius with a double spiral. On being rolled under the microscope it has, in another position, the appearance of 3 distinct (concentric) shells, one outside the other, the innermost being somewhat oblong, the other two rounder. In this last position, an indefinite contour of an inner, smaller shell is seen in the innermost one. From which one may probably conclude that the innermost of the three shells is double, Larnacilla-shaped or trizonal (according to Haeckel's designations). I have not, however, succeeded in seeing this clearly. From this shell there extends, on both sides, a transverse girdle. Which winds itself into a spiral about the largest axis of the inner shell, the longitudinal or principal axis (after Haeckel). These

\footnotetext{
Explanation of Plate 4. fig. 1. Androcyclas gamphonycha Jørgensen, 1905: a, lectotype, PMO224.467, slide \#44 (K38/1), Herlöfjord 21 June 1898, 0-400 m; b, original drawing by Jørgensen (1905, pl. 17, fig. 92). fig. 2. Androcyclas gamphonycha Jørgensen, 1905: a, paralectotype 1, PMO224.468, slide \#45 (K38/3). Slide label Pterocorys gamphonyxos, Ofoten, 7 February 1898, 0-100 m; b, original drawing of Jørgensen (1905, pl. 17, fig. 93). fig. 3. Androcyclas gamphonycha Jørgensen, 1905. Paralectotype 2 (left) and 3 (right), PMO224.469/1 (left) and PMO224.469/2 (right), slide \#41 (M37/0). Slide label: Pterocorys androcyclas, Vestfjorden 1 February 1899, 0-200 m. fig. 4. Androcyclas gamphonycha Jørgensen, 1905. Paralectotype 4, PMO224.470/1, slide \#39 (O37/2 lower left). Slide label Pterocorys amblycephalis, Tranødybet 6 February 1899, 0-630 m. fig. 5. Androcyclas gamphonycha Jørgensen, 1905. Paralectotype 5, PMO224.470/2, slide \#39 (O37/2 upper right). Slide label Pterocorys amblycephalis, Tranødybet 6 February 1899, 0-630 m. fig. 6. Androcyclas gamphonycha Jørgensen, 1905. Original drawing of Jørgensen (1905, pl. 17, fig. 97).

fig. 7. Campylacantha cladophora Jørgensen, 1905. Lectotype, PMO224.471/1, slide \#36 (M37/1 upper left). Kvænangen 24 January 1899 and Ofoten 7 February 1899 (i.e. specimens from two different stations pooled). fig. 8. Campylacantha cladophora Jørgensen, 1905. Paralectotype 1, PMO224.471/2, \#slide 36 (M37/1 middle). Kvænangen 24 January 1899 and Ofoten 7 February 1899 (i.e. specimens from two different stations pooled). fig. 9. Campylacantha cladophora Jørgensen, 1905. Paralectotype 2, PMO224.471/3, \#slide 36 (M37/1 lower left). Kvænangen 24 January 1899 and Ofoten 7 February 1899 (i.e. specimens from two different stations pooled). fig. 10. Campylacantha cladophora Jørgensen, 1905. Original drawing of Jørgensen (1905, pl. 12, fig. 47a). fig. 11. Ceratospyris hyperborea Jørgensen, 1905. Lectotype, PMO224.472, slide \#56 (L38/0). Vestfjord 1 February 1899, 0-200m. fig. 12. Ceratospyris hyperborea Jørgensen, 1905. Original drawing of Jørgensen (1905, pl. 13, fig. 49). fig. 13. Cladoscenium limbatum Jørgensen, 1905: a, lectotype, PMO224.473, slide \#66 (L38/0) Vesteraalen 19 January 1899, 0-700 m; b, original drawing of Jørgensen (1905, pl. 15, fig. 74). Note: where two or more images (a, b, -) are not otherwise described they represent different focal planes. Scale bar $100 \mu \mathrm{m}$.
} 

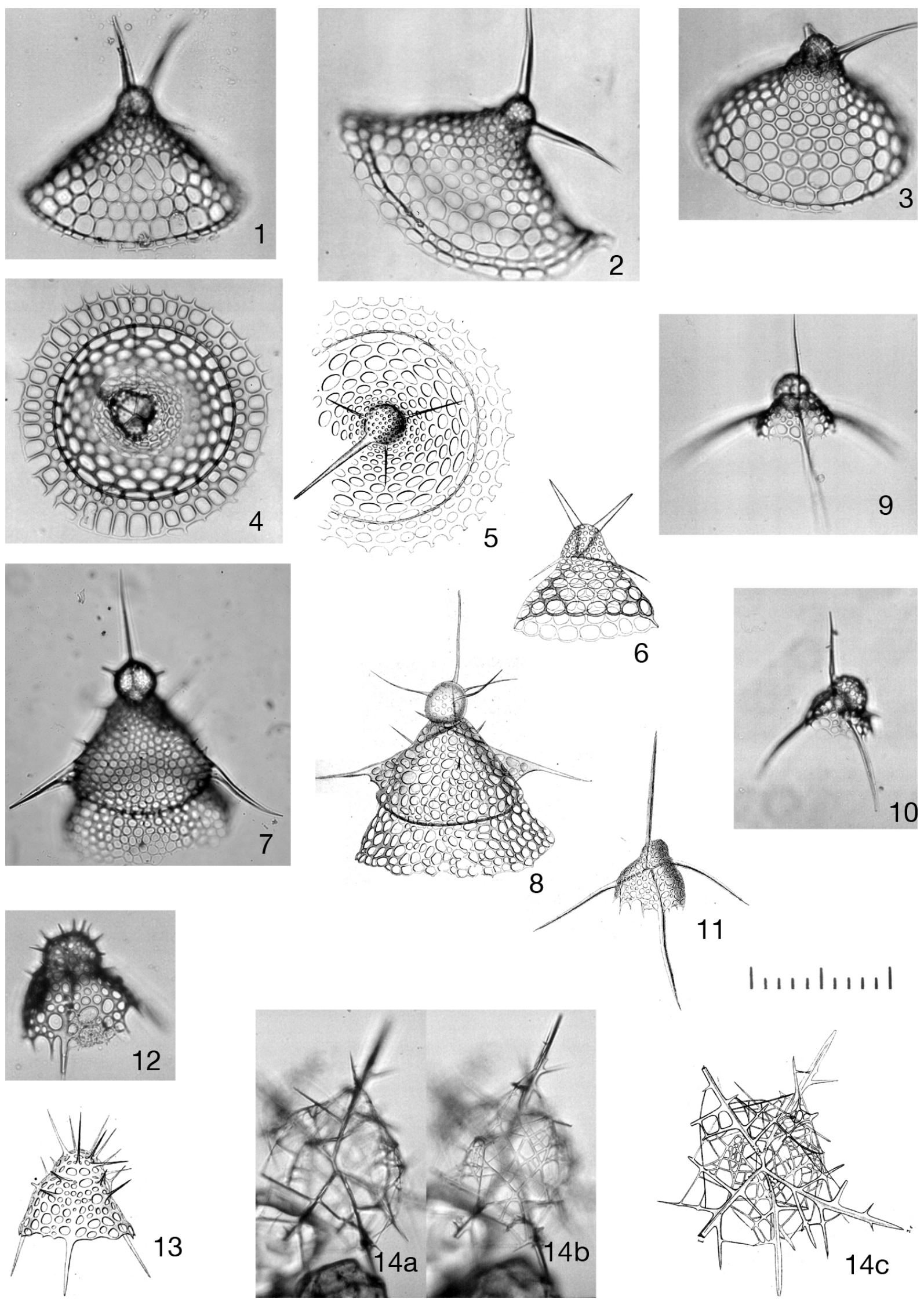

$|111| 1111 \mid$, 
two spirals give rise to the appearance of a Lithelius with a double spiral, when looked at from above (transverse section, after Haeckel apical view). In a certain, a little oblique, position one gets again a more or less indefinite impression of a single spiral. In each spiral there is only a little more than one turn. Pores somewhat uneven, not large. Numerous, long, narrow, needleshaped radial spines. (Cfr. also Jörgensen 1.c. [1900]). One of the most frequent radiolaria in the north, sometimes also rather numerous, especially in ocean samples. Distribution: Also rather frequent on the west coast. Known too from a few places in the in the Norwegian Ocean, where it occurs together with southern forms. NOTE: What is in one instance in the tables entered as Lithelius spiralis HCK. is very uncertain, and it is probably only a form of Larcospira minor, which, as already mentioned, in certain positions gives the appearance of a single spiral. The same is the case with regard to L. spiralis JÖRG. L. 91 [1900], p. 66.

Lectotype. PMO224.461/1; Plate 2, fig. 7a, b; Slide \#58 (Q46/3).

Paralectotype 1. PMO224.461/2; Plate 2, fig. 8a, b; Slide \#58 (N37/1).

Paralectotype 2. PMO224.462; Plate 2, fig. 9a, b; Slide \#73 (M38/1).

Paralectotype 3. PMO224.461/3; Plate 2, fig. 10a, b; Slide \#58 $(\mathrm{O} 38 / 1)$.

Remarks. This species is rather complex in its structure and may be misidentified if studied in permanent mounted slides where specimens cannot be rotated. Three principal views may occur depending on the position of the specimen: (1) three perfectly concentric or somewhat elongated spheres may be seen; (2) when viewed from above (transverse section, after Haeckel's apical view) two spirals give an impression of a Lithelius specimen; and (3) in an oblique position one gets the impression that only one single spiral is present. One single spiral brings us to Lithelius spiralis Haeckel, 1860 (p. 843) (see also descriptions of this species in Jørgensen, 1900), a species that Jørgensen did not discuss separately in his 1905 paper. He only mentioned in this latter work that he perhaps had misidentified some specimens as Lithelius spiralis which he should have named Larcospira minor instead. Many researchers use the name Lithelius minor, as originally described by Jørgensen (1900), and some also synonymize L. minor with Lithelius spiralis Haeckel, 1860 (see drawings in Haeckel, 1862, pl. 27, figs 6-7). To determine whether these two are the same species or not one has to consult Haeckel's type collection. Until then we agree with Jørgensen's decision that the innermost of the three shells is double, Larnacilla-shaped or trizonal.
Larcospira minor (Jørgensen, 1900) is regarded as the correct formal name.

Leptosphaera arachnoides Jørgensen, 1900

(No illustration)

1900 Leptosphaera arachnoides Jørgensen: 56 (not figured).

\section{Original description (Jørgensen, 1900)}

Die innere Gitterkugel mit fast regelmässigen, ziemlich dünnwandigen, grossen Maschen $(0,011-0,015 \mathrm{~mm}$. breit), ungefähr 4 oder 5 auf dem Radius. Radialstacheln schmal nadelförmig, in allen Ecken, bis $0,030 \mathrm{~mm}$. lang, unweit des distalen Endes durch sehr feine Querfäden mit einander verbunden. Diese feinen Fäden bilden die äussere, arachnoidale Gitterkugel.

Durchmesser der inneren Kugel 0,080 mm., der äusseren ungefähr 0,140.

Sehr selten: Herløfjord, 28/2 1898.

Vielleicht ist diese Art identisch mit der oben beschriebenen Acanthosphaera teneriformis, da die feine arachnoidale Hülle leicht hinfällig ist, übrigens auch leicht übersehen werden kann. Meine Art entfernt sich sehr von HCK.'S Leptosphaera -Arten, gehört daher wohl auch nicht naturgemäss zu dieser Gattung.

Types. Not defined.

Remarks. Leptosphaera belongs to the Astrosphaerida which have two extracapsular cortical shells without byspines, connected by long prismatic radial spines according to Haeckel (1887, p. 243). Unfortunately, no specimens fitting this description have been observed in Jørgensen's radiolarian slides. Jørgensen (1900) stated that this species develops a delicate arachnoidal (web-like) shell, as opposed to Acanthosphaera teneriformis where this shell is totally missing. However, Jørgensen suggests that these two species might be identical. If so, then the one-shelled A. teneriformis is a juvenile stage of the two-shelled L. arachnoides.

\section{Streblacantha circumtexta (Jørgensen, 1900)}

$$
\text { (P1. 3, figs 1-5) }
$$

1900 Sorolarcus circumtextus Jørgensen: 65 (not figured). 1905 Streblacantha circumtexta (Jørgensen, 1900); Jørgensen: 121-122; pl. 11, fig. 46a-g, pl. 12, fig. 46h-k.

\section{Original description (Jørgensen, 1900)}

Umriss der Schale unregelmässig eiförmig-rundlich. Zur inneren Schale gehörig sieht man einen deutlichen transversalen Gürtel, 0,058 mm. lang,

\footnotetext{
Explanation of Plate 5. fig. 1. Clathrocyclas craspedota (Jørgensen, 1900). Lectotype, PMO224.474, slide \#66 (L40/0), Vesteraalen 19 January 1899, 0-700 m. fig. 2. Clathrocyclas craspedota (Jørgensen, 1900). Paralectotype 1, PMO224.475/1, slide \#13 (M35/2), Vestfjord 1 February 1899, 0-200 m. fig. 3. Clathrocyclas craspedota (Jørgensen, 1900). Paralectotype 2, PMO224.475/2, slide \#13 (M35/0), Vestfjord 1 February 1899, 0-200 m. fig. 4. Clathrocyclas craspedota (Jørgensen, 1900). Paralectotype 3, PMO224.475/3, slide \#13 (M35/3), Vestfjord 1 February 1899, 0-200m. fig. 5. Clathrocyclas craspedota (Jørgensen, 1900). Original drawing of Jørgensen (1905, pl. 17, fig. 98). fig. 6. Clathrocyclas craspedota (Jørgensen, 1900). Original drawing of Jørgensen (1905, pl. 17, fig. 99a). fig. 7. Dictyoceras xiphephorum Jørgensen, 1900. Lectotype, PMO224.476, slide \#16 (M39/3), Kvænangen 24 January 1899, 0-140 m. fig. 8. Dictyoceras xiphephorum Jørgensen, 1900. Original drawing of Jørgensen (1905, pl. 18, fig. 101b). fig. 9. Dictyophimus clevei Jørgensen, 1900. Lectotype, PMO224.477, slide \#66 (K38/4), Vesteraalen 19 January 1899, 0-700 m. fig. 10. Dictyophimus clevei Jørgensen, 1900. Paralectotype, PMO224.478, slide \#67 (O40/0), Vesteraalen 19 January 1899, 0-700 m. fig. 11. Dictyophimus clevei Jørgensen, 1900. Original drawing of Jørgensen (1905, pl. 5, fig. 26). fig. 12. Dictyophimus histricosus Jørgensen, 1905. Lectotype, PMO224.479, slide \#68 (M36/4) Vesteraalen 19 January 1899, 0-700 m. fig. 13. Dictyophimus histricosus Jørgensen, 1905. Original drawing of Jørgensen (1905, pl. 16, fig. 89a). fig. 14. Euscenium corynephorum Jørgensen, 1900: a, b, lectotype, PMO224.480, slide \#11 (N37/1) Raftsund 3 March 1899, 0-260 m; c, original drawing of Jørgensen (1905, pl. 15, fig. 70). Note: where two or more images (a, b, -) are not otherwise described they represent different focal planes. Scale bar $100 \mu \mathrm{m}$.
} 

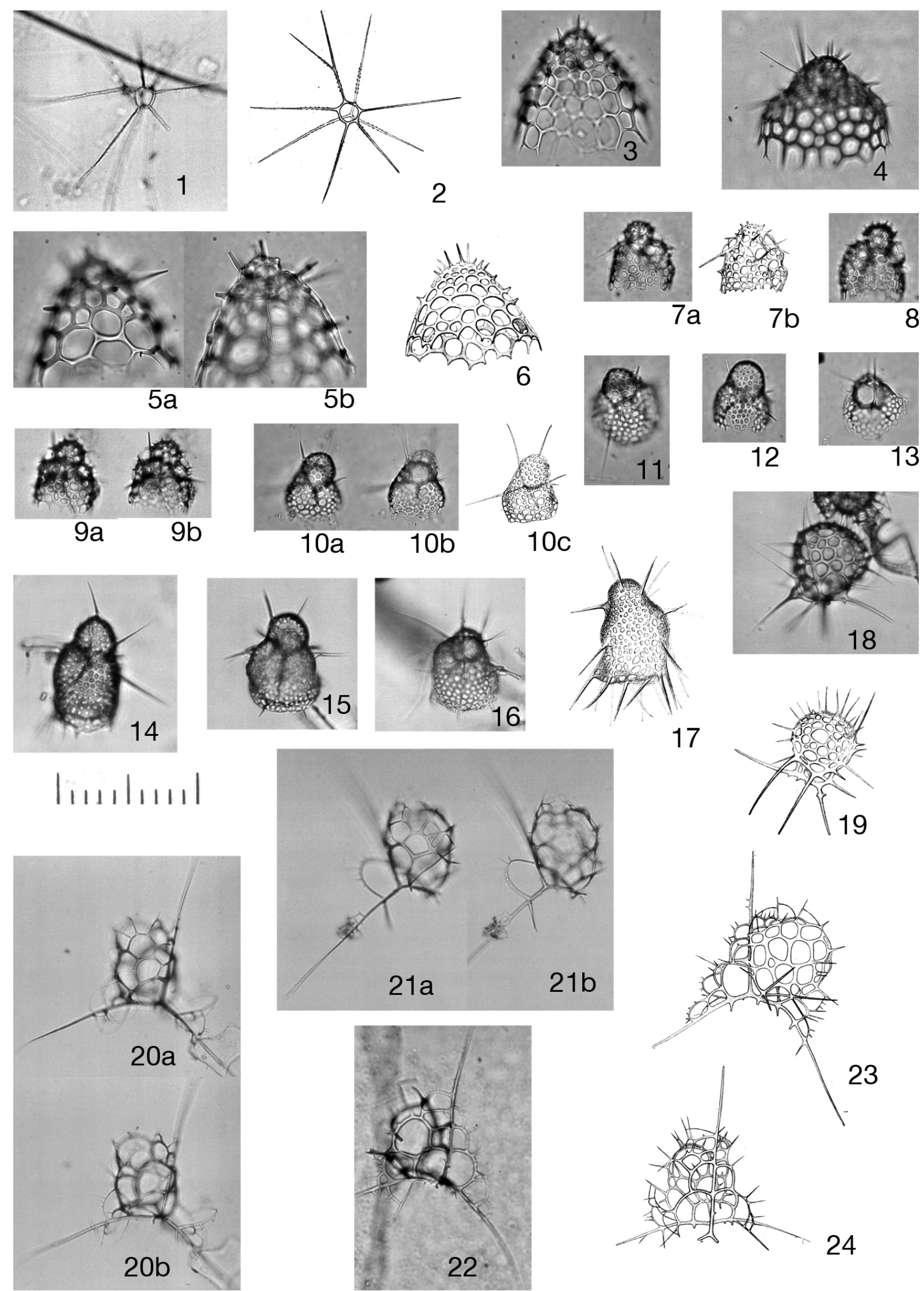
0,020 breit (an der Mitte), mit kleinen, unregelmässig länglichen und rundlichen, 0,003 bis $0,008 \mathrm{~mm}$. langen Poren.

Um diese Schale herum sind durch kräftige Radialstacheln und zwischenliegende, verschieden gestellte Gitterflügel zahlreiche Kammern aufgebaut, etwa drei Stockwerke, scheinbar ganz regellos. Mehrere (6 bis 10?) Radialbalken laufen in kräftige Stacheln an verschiedenen Stellen über die Schale hinaus, bis $0,088 \mathrm{~mm}$. hervorragend, von sehr ungleicher Länge. Poren der Gitterflügel unregelmässig rundlich und länglich, sehr ungleich gross, 0,004 bis $0,010 \mathrm{~mm}$. und grösser. Auf der Aussenseite der Schale finden sich zahlreiche nadelförmige Nebenstacheln von wechselnder Länge, die meisten verästelt mit bogenförmig verbundenen Aesten. Hierdurch wird eine zarte spongiöse Aussenschale um die eigentliche Gitterschale gebildet. Der Abstand beider beträgt 0,010 bis $0,020 \mathrm{~mm}$. Viele der Nebenstacheln laufen in ziemlich langen feinen Spitzen aus. An dem breiteren Ende der Schale waren an den beobachteten Exemplaren alle Stacheln länger und kräftiger, die spongiöse Aussenschale aber wenig entwickelt. An dem schmäleren Ende fand sich ein kräftiger, nicht sehr langer Stachel. Die spongiöse Schale war von hier ab bis gegen das breitere Ende wohl entwickelt.

Länge (Aussenschale mitgerechnet) 0,190 bis $0,210 \mathrm{~mm}$. Breite $0,180 \mathrm{~mm}$.

Sehr selten, in Tiefseeproben: Mai, August.

\section{Original description (Jørgensen, 1905)}

This is also a very difficult form to define, and I have not yet succeeded in getting a clear insight into its structure. It can, however, not belong to the genus Sorolarcus HCK., as I at first thought. There appear to be about 12 strong radial spines, of the same shape as those of Phorticium pylonium CL., but protruding much further. They are more or less round, not three edged. The outline of the shell in most positions is a broad oval, in a few, almost round. Some optical sections show inner spirals, then a double spiral as in Larcospira minor, other sections show at least 3 shells one outside the other; perhaps with several chambers (only, indistinctly seen). On the smaller and simpler forms (cfr. Pl. XI, f. 46, c, d; pl. XII, f. $46 \mathrm{k}, 1$ ), which I have taken to be specimens in an early stage of development, a single central chamber and spiral twists, which appear to form a snail spiral, may be seen. On the whole it seems to me at present, that this species may best be placed in the genus Streblacantha HCK., though it may prove not to belong to this genus either. The outer shell shows a more or less irregular structure and very uneven pores, from rather small to large ones and large holes. On the outside of larger (more developed) forms there are also more or less well developed byspines, very various as regards length and development, from small subulate ones with a rather wide base, to long, narrow needles. When more developed, these byspines are more or less connected through fine branches to an outer, spongy case immediately outside the outer shell. This spongy case is, however, rarely much developed, and seems then to be confined to - or at any rate most developed at - the one end of the shell. Cfr. also Jörgensen 1.c. [1900]. Rare, and generally only singly, the small, younger individuals rather more frequent: The Vest Fiord I, 13/1, 0-180 m; Henningsvær, 17/1, $0-180 \mathrm{~m}$; the sea off Gaukværö, 19/1, 0-700 m; Skroven, 1/2, 0-300 m; 4/2, 350-300m, 4/4, 0-150 m; The Raftsund, 3/2, 0-260m; The Tys Fiord I, 28/3, 0-700m.

Lectotype. PMO224.463; Plate 3, fig. 1a, b; Slide \#52 (O37/2). Plate 3, fig. 2 original drawing by Jørgensen (1905, fig. 46a).

Paralectotype 1. PMO224.464/1; Plate 3, fig. 3; Slide \#65 (N36/2).

Paralectotype 2. PMO224.464/2; Plate 3, fig. 4a, b; Slide \#65 (N38/1).

Paralectotype 3. PMO224.464/3; Plate 3, fig. 5a, b; Slide \#65 (O37/0).

Remarks. This species can be confused with juvenile stages of Phorticium clevei (see Tetrapylonium clevei for more discussion); however, $S$. circumtexta never develops a quadrangular outline. Streblacantha circumtexta (Jørgensen, 1900) is regarded as the correct formal name.

Stylodictya aculeata Jørgensen, 1905 (No illustration)

1905 Stylodictya aculeata Jørgensen: 119-120; pl. 10, fig. 41a-c.

Explanation of Plate 6. fig. 1. Gonosphaera primordialis Jørgensen, 1905. Lectotype, PMO224.481, slide \#35 (H32/0), Michael Sars, St. 3, 18 July 1900, 200-530 m. fig. 2. Gonosphaera primordialis Jørgensen, 1905. Original drawing of Jørgensen (1905, pl. 14, fig. 64). fig. 3. Helotholus histricosa Jørgensen, 1905. Lectotype, PMO224.482/1, slide \#40 (M40/0 bottom), Vestfjord 1 February 1899, 0-200m. fig. 4. Helotholus histricosa Jørgensen, 1905. Paralectotype 1, PMO224.483, slide \#62 (N43/1), Skraaven 4 February 1899, 0-350 m. fig. 5. Helotholus histricosa Jørgensen, 1905: a, b, Paralectotype 2, PMO224.482/2, \#slide 40 (M40/0 top), Vestfjord 1 February 1899, 0-200 m. fig. 6. Helotholus histricosa Jørgensen, 1905. Original drawing of Jørgensen (1905, pl. 16, fig. 87a). fig. 7. Lithomelissa hystrix Jørgensen, 1900: a, lectotype, PMO224.484/1, slide \#30 (M34/0 bottom), Vestfjord 1 February 1899, 0-200 m; b, original drawing of Jørgensen (1905, pl. 16, fig. 85). fig. 8. Lithomelissa hystrix Jørgensen, 1900. Paralectotype 1, PMO224.484/2, slide \#30 (M34/0 middle), Vestfjord 1 February 1899, 0-200 m. fig. 9. Lithomelissa hystrix Jørgensen, 1900: a, b, paralectotype 2, PMO224.484/3, slide \#30 (M34/2), Vestfjord 1 February 1899, 0-200 m. fig. 10. Lithomelissa setosa Jørgensen, 1900: a, b, lectotype, PMO224.485/1, slide \#34 (O39/4 lower right) Kvænangen 24 January 1899, 0-140 m; c, original drawing of Jørgensen (1905, pl. 18, fig. 108a). fig. 11. Lithomelissa setosa Jørgensen, 1900. Paralectotype 1, PMO224.485/2, slide \#34 (O39/4 top), Kvænangen 24 January 1899, 0-140 m. fig. 12. Lithomelissa setosa Jørgensen, 1900. Paralectotype 2, PMO224.485/3, slide \#34 (O40/3 top), Kvænangen 24 January 1899, 0-140 m. fig. 13. Lithomelissa setosa Jørgensen, 1900. Paralectotype 3, PMO224.485/4, slide \#34 (O40/3 bottom), Kvænangen 24 January 1899, 0-140 m. fig. 14. Lithomelissa setosa v. belonophora Jørgensen, 1900. Lectotype, PMO224.497/1, \#slide 73 (N37/0), Herlöfjord, February-December 1899, 0-400 m. fig. 15. Lithomelissa setosa v. belonophora Jørgensen, 1900. Paralectotype 1, PMO224.497/2, slide \#73 (M36/4), Herlöfjord, February-December 1899, 0-400 m. fig. 16. Lithomelissa setosa v. belonophora Jørgensen, 1900. Paralectotype 2, PMO224.497/3, slide \#73 (M37/3), Herlöfjord, February-December 1899, 0-400 m. fig. 17. Lithomelissa setosa v. belonophora Jørgensen, 1900. Original drawing of Jørgensen (1905, pl. 4, fig. 22). fig. 18. Peridium longispinum Jørgensen, 1900. Lectotype, PMO224.486, slide \#67 (O40/0), Vesteraalen, 19 January 1899, 0-700 m. fig. 19. Peridium longispinum Jørgensen, 1900. Original drawing of Jørgensen (1905, pl. 16, fig. 80). fig. 20. Phormacantha hystrix (Jørgensen, 1900): a, b, lectotype, PMO224.487/1, slide \#33 (M38/4 upper right), Vestfjord 1 February 1899, 0-200 m. fig. 21. Phormacantha hystrix (Jørgensen, 1900): a, b, paralectotype 1, PMO224.487/2, \#slide 33 (M38/4 lower left), Vestfjord 1 February 1899, 0-200 m. fig. 22. Phormacantha hystrix (Jørgensen, 1900). Paralectotype 2, PMO224.488, slide \#62 (L30/4), Skraaven 4 February 1899, 0-350 m. fig. 23. Phormacantha hystrix (Jørgensen, 1900). Original drawing of Jørgensen (1905, pl. 14, fig. 59a). fig. 24. Phormacantha hystrix (Jørgensen, 1900). Original drawing of Jørgensen (1905, pl. 14, fig. 59b). Note: where two or more images (a, b, -) are not otherwise described they represent different focal planes. Scale bar $100 \mu \mathrm{m}$. 

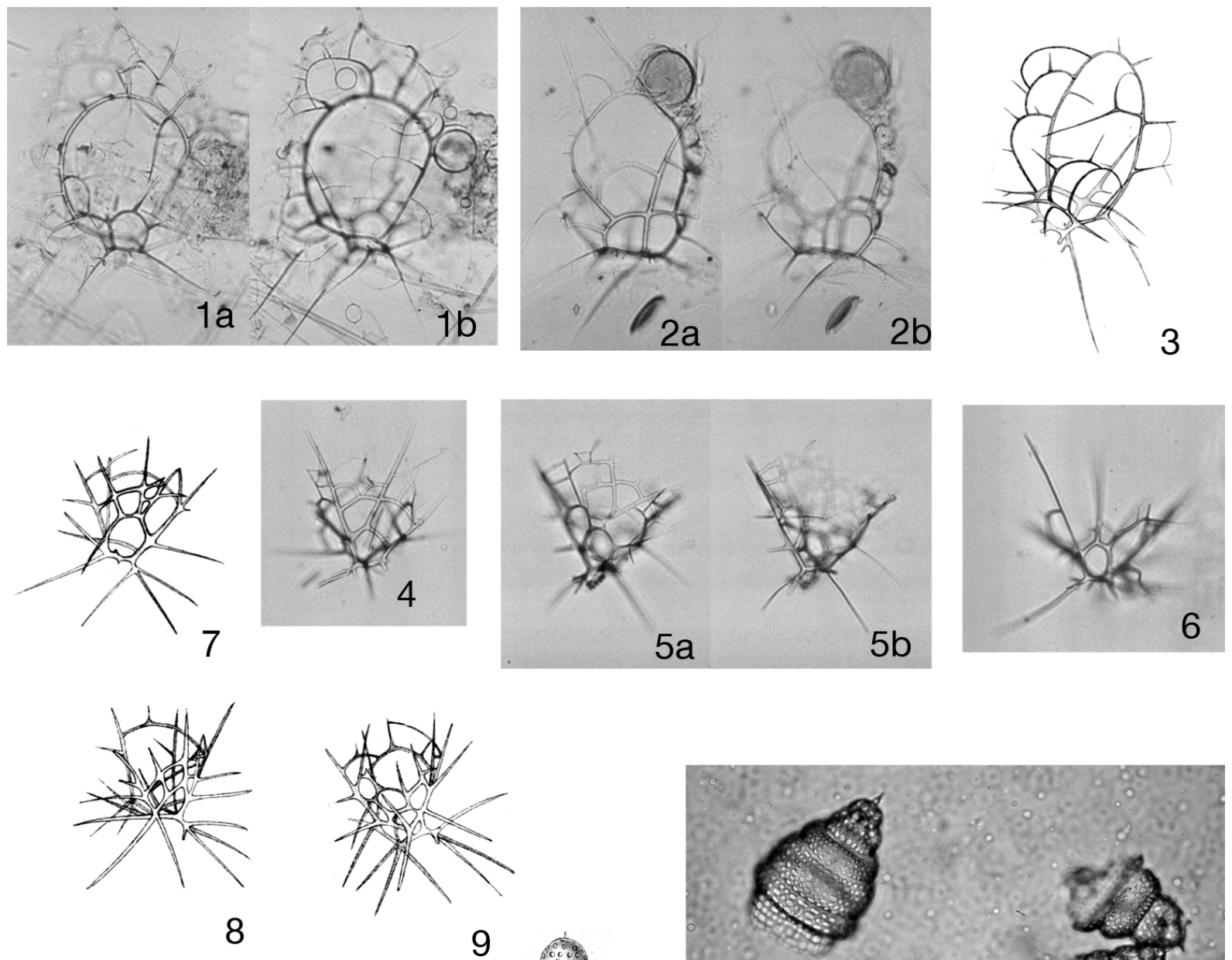

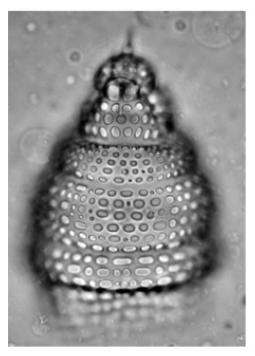

12

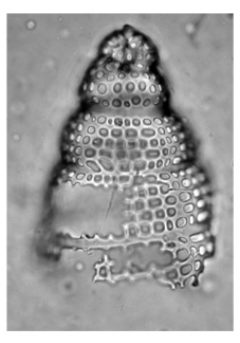

13

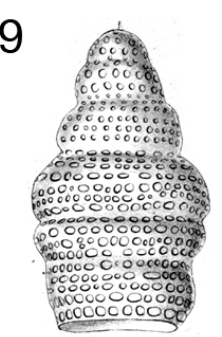

10

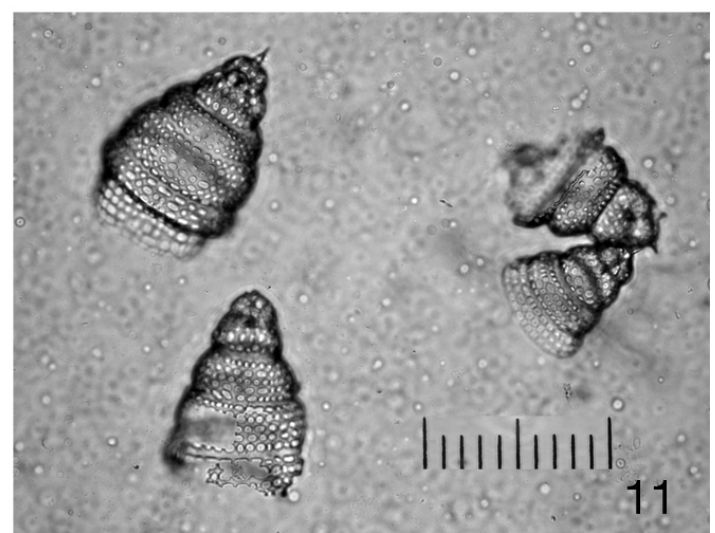

11
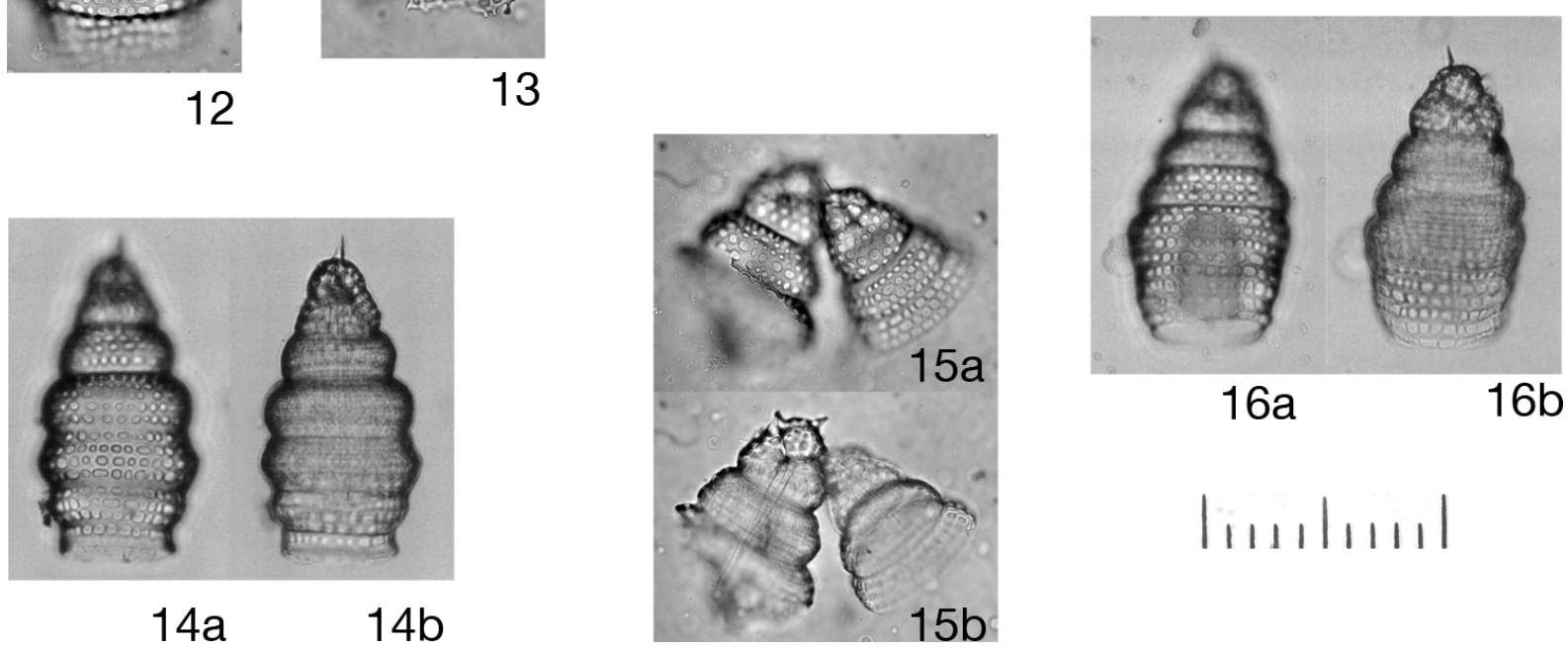

|i11,1111 


\section{Original description (Jørgensen, 1905)}

This species corresponds well in structure to the foregoing one [Stylodictya validispina], but differs in a marked degree with regard to its radial spines, which are particularly numerous, and are more irregularly placed, not all lying at the same level, that of the disc, but pointing obliquely beyond and beneath it. Shape of the shell in side view: Broadly linear, with rounded corners and ends. From the centre to near the margin, there are small scattered punctiform byspines. System of rings: On the whole like the preceding, only the rings are more irregular in shape and width. Outside the fourth ring there seems to be traceable the beginning of a 5th which is as yet not formed. Pores: On the whole like those of the preceding. Very large pores here and there on the edge of the disc, which would probably have formed several smaller ones later on. The byspines are very scattered, fewer in number than in the preceding species, but distributed over a larger part of the disc. Radial spines: The rings are united similarly to those in the preceding species [Stylodictya tenuispina, S. validispina], but the number of radial spines around the disc is larger, more than 30 . The spines are narrower and more irregularly developed, some being a little bent, turned outwards and obliquely upwards, not all at the same level, equatorial, but distributed over the broad, rounded margin of the disc. The length of the spines is about the same as in the preceding species. Byspines: Very similar to those of the preceding species, but more scattered and distributed over the whole of the disc nearly out to the margin. Dimensions: The diameter of the inmost shell $12 \mu$, of the first ring about $38 \mu$, of the second $54 \mu$, of the third $85 \mu$, of the fourth $110 \mu$. Pores uneven, most of them being $2-4 \mu$. The spines protrude as much as to $30 \mu$. The disc is $28 \mu$ in thickness. This form appears to differ considerably from the other species on account of the irregularly placed marginal spines. The specimen illustrated is probably not quite fully developed.

Types. Not defined.

Remarks. We have not been able to locate any Stylodictya species in Jørgensen's slide collection that fit this description. Probably the same as Stylodictya validispina (see Remarks) which has been emended to S. stellata.

\section{Stylodictya aspera Jørgensen, 1900} (No illustration)

1900 Stylodictya aspera Jørgensen: 62-63 (not figured).

\section{Original description (Jørgensen, 1900)}

In der Flächenansicht sieht man einen innersten Ring (Durchmesser ungefähr $0,015 \mathrm{~mm}$.), der durch eine Spirale, die bald ringförmig in sich selbst zurückläuft, umgeben ist (Durchmesser dieses zweiten Ringes $0,030 \mathrm{~mm}$.). Ausserhalb dieses Ringes finden sich 5 concentrische, ein wenig unregelmässig eckige Ringe, deren Durchmesser allmählich zunehmen.
Durchmesser des letzten (also der ganzen Scheibe) 0,114 mm., ungefähr $1 \frac{1}{2}$ mal so gross wie der des ersten vollständigen Ringes. Poren etwas ungleich gross, rundlich, an allen Ringen etwa gleich gross, breitwandig, an den äusseren Ringen $2 \frac{1}{2}$ à 3 , an den inneren 2 auf der Breite des Ringes. Ausserhalb des letzten Ringes an mehreren Stellen Stücke eines Ringes, der noch ganz unentwickelt schien. Radialstacheln nadelförmig, in der Aequatorialebene ungefähr 25, 0,012 bis $0,020 \mathrm{~mm}$. hervorragend, die längsten bis zweimal so lang wie die Breite des äussersten Ringes, die meisten aber wenig länger als diese. Auf der ganzen Aussenseite der Scheibe kurze, schmal konische Nebenstacheln. Diese Art scheint am nächsten mit Stylodictya setigera HCK. (L. 69 [1887], p. 512) verwandt zu sein. Sie sieht der S. heliospira HCK. (L. 69 [1887]. T. 41, F. 8) sehr ähnlich, die auch kurze Nebenstacheln auf der Aussenseite der Scheibe zu besitzen scheint, weicht aber durch viel weniger entwickeltes spiraliges Wachsthum ab.

Sehr selten, nur einmal beobachtet: Herløfjord, 25/4 1898 (Tiefseeprobe).

Types. Not defined.

Remarks. According to Jørgensen (1900) this is a very rare species. In 1905 he mentioned this species only in a note 'Stylodictya aspera JÖRG. (L. 91 [1900], p. 61) is a fourth species'. This species has not been identified during the examination of Jørgensen's slides so we are not able to verify its validity. See also remarks for Stylodictya validispina.

\section{Stylodictya tenuispina Jørgensen, 1905}

(Pl. 3, fig. 6a-c)

1905 Stylodictya tenuispina Jørgensen: 118-119; pl. 10, fig. 39a-c.

\section{Original description (Jørgensen, 1905)}

Shape of the shell in side view: Almost linear, though somewhat thicker in the middle and slightly narrowed towards the ends which are rounded off. A small portion of central part of the shell is strongly convex, forming a protruding ball shaped cap on either side (pl. 10, f. 39c). System of Rings: From an inner little spherical shell 4 radial rods extend in the form of a cross to the 1st ring, which forms an irregular quadrangle with rounded corners. The radial rods pass through the middle of the sides. Beyond this ring there are, on the specimen illustrated, 6-7 rings, each joined to the one next outside by a continually increasing number of radial rods. It is likely that the number of the rings increases as time goes on. The inner rings are still somewhat angular, the outer, however, more regular. The outmost ones seem, however, again to show irregularity, which perhaps, disappears with age. Pores: The strongly convex central part, which corresponds fairly well to the 1st ring, has unusually large, roundish, hexagonal pores, which are much broader than the

\footnotetext{
Explanation of Plate 7. fig. 1. Plectacantha trichoides Jørgensen, 1905: a, b, lectotype, PMO224.492, slide \#35 (W36/1), Michael Sars, St. 3, 18 July 1900, 200-530 m. fig. 2. Plectacantha trichoides Jørgensen, 1905: a, b, paralectotype, PMO224.493, slide \#42 (N40/0), Storfjord 18 July 1900, 200$530 \mathrm{~m}$. fig. 3. Plectacantha trichoides Jørgensen, 1905. Original drawing of Jørgensen (1905, pl. 13, fig. 58). fig. 4. Plectacantha oikiskos Jørgensen, 1905. Lectotype, PMO224.489, slide \#35 (S42/2), Michael Sars, St. 3, 18 July 1900, 200-530 m. fig. 5. Plectacantha oikiskos Jørgensen, 1905: a, b, Paralectotype 1, PMO224.490, slide \#10 (N41/3), Vestfjord 1 February 1899, 0-200m. fig. 6. Plectacantha oikiskos Jørgensen, 1905. Paralectotype 2, PMO224.491, slide \#64 (D35/4), Vestfjord 1 February 1899, 0-200 m. fig. 7. Plectacantha oikiskos Jørgensen, 1905. Original drawing of Jørgensen (1905, pl. 13, fig. 55a). fig. 8. Plectacantha oikiskos Jørgensen, 1905. Original drawing of Jørgensen (1905, pl. 13, fig. 55b). fig. 9. Plectacantha oikiskos Jørgensen, 1905. Original drawing of Jørgensen (1905, pl. 13, fig. 55c). fig. 10. Stichocorys seriata Jørgensen, 1905. Original drawing of Jørgensen (1905, pl. 18, fig. 103). fig. 11. Stichocorys seriata Jørgensen, 1905. Four specimens in slide \#25, Kvænangen 24 January 1899, no depth given. Specimens on the left are same as figs 12-13, specimens on the right are same as fig. 15a, b. fig. 12. Stichocorys seriata Jørgensen, 1905. Lectotype, PMO224.494/1, slide \#25 (N38/0 bottom). fig. 13. Stichocorys seriata Jørgensen, 1905. Paralectotype 1, PMO224.494/2, slide \#25 (N38/0 middle), Kvænangen 24 January 1899. fig. 14. Stichocorys seriata Jørgensen, 1905: a, b, paralectotype 2, PMO224.495, slide \#66 (K39/2), Vesteraalen 19 January 1899, 0-700 m. fig. 15. Stichocorys seriata Jørgensen, 1905: a, b, paralectotype 3-4, PMO224.494/3 (left - a), PMO224.494/4 (right - b), slide \#25 (N38/0 middle), Kvænangen 24 January 1899. fig. 16. Stichocorys seriata Jørgensen, 1905: a, b, paralectotype 5, PMO224.496, slide \#68 (N36/3), Vesteraalen 19 January 1899, 0-700 m. Note: where two or more images (a, b, -) are not otherwise described they represent different focal planes. Scale bar $100 \mu \mathrm{m}$.
} 

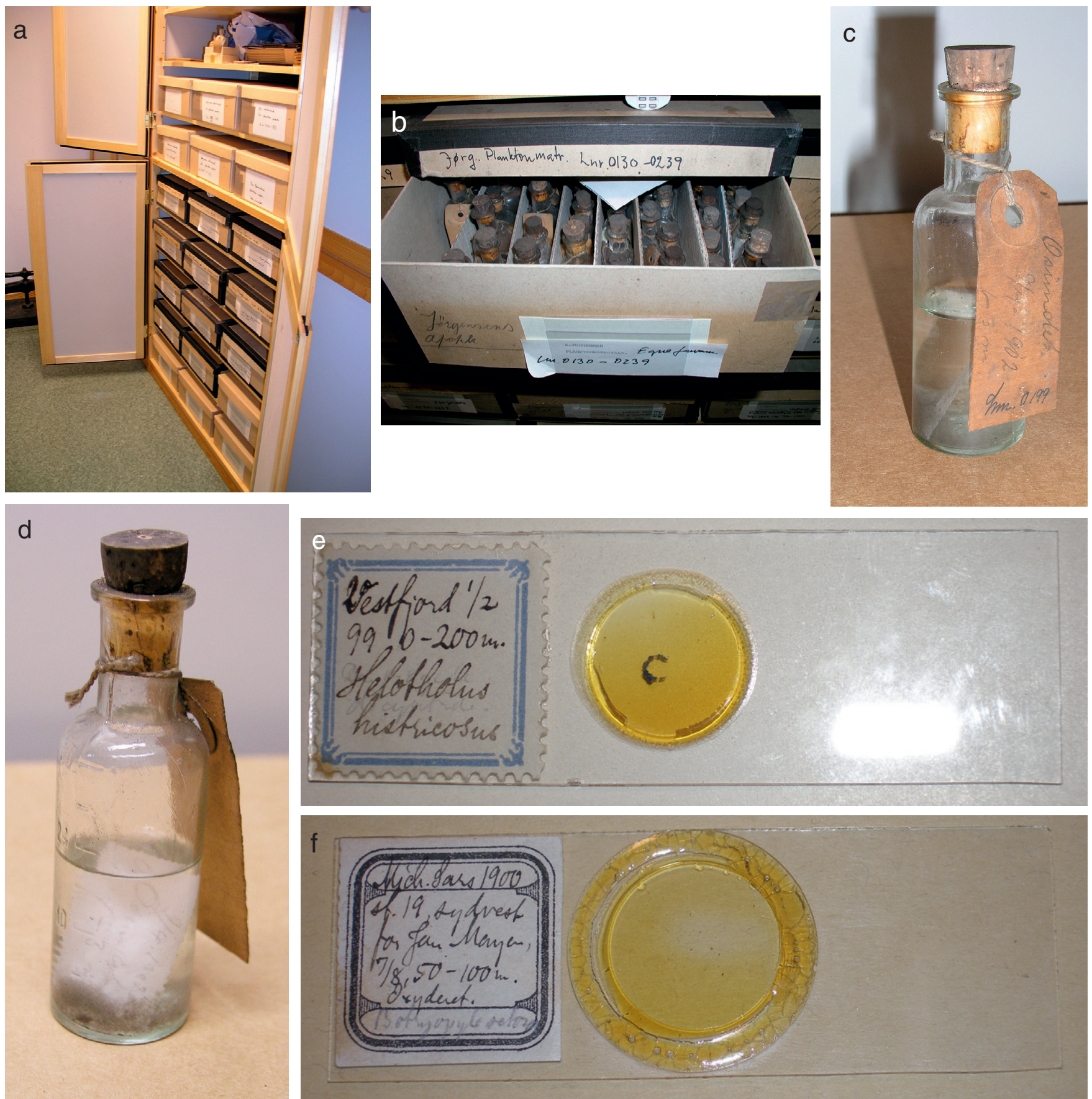

Fig. 2. (a, b) Jørgensen’s 'apotek' at the University of Bergen. (c, d) Small bottles containing plankton samples collected during cruises off the western and northern coast of Norway 1897-1900. (e, f) Examples of Jørgensen's radiolarian slides (see also Pls 8-10).

separating walls. The rest of the pores are exceptionally small and uneven in size, most of them being narrower than the intermediate spaces, or of the same width as these, very little larger outwards, 2-3 on the space between two rings. Radial spines: Around the disc (in the imperfectly developed individual, cfr. the illustration) a few very narrow, needle-shaped radial spines protrude, apparently in no definite order. Numerous radial rods are to be found between the outer rings; some go through two or more, others again only connecting two rings. Byspines: Very small, almost punctiform, short byspines, largest and closest together on the convex central part, the others being only scattered over the disc. Dimensions: Diameter of 1 st ring $30 \mu$, of 2 nd $42 \mu$, of 3 rd $59 \mu$, of 4 th $78 \mu$, of 5 th $98 \mu$, of 6 th $120 \mu$, of 7 th $144 \mu$, 8th ring irregular and as yet incomplete. The rings are thus somewhat broader ontwards. The large pores on the central part $5-6 \mu$, the small ones only $1.5-3-4 \mu$. The few piercing radial spines only protrude as far as a distance equal to the breadth of the rings. The disc is $37 \mu$ thick at the convex central part, outside this $30 \mu$, only about half as thick at the margin. The specimen which is illustrated seems to me to suggest that the few piercing radial spines are in reality radial rods which penetrate several rings, similarly to those which are seen here and there farther in between the rings. In 


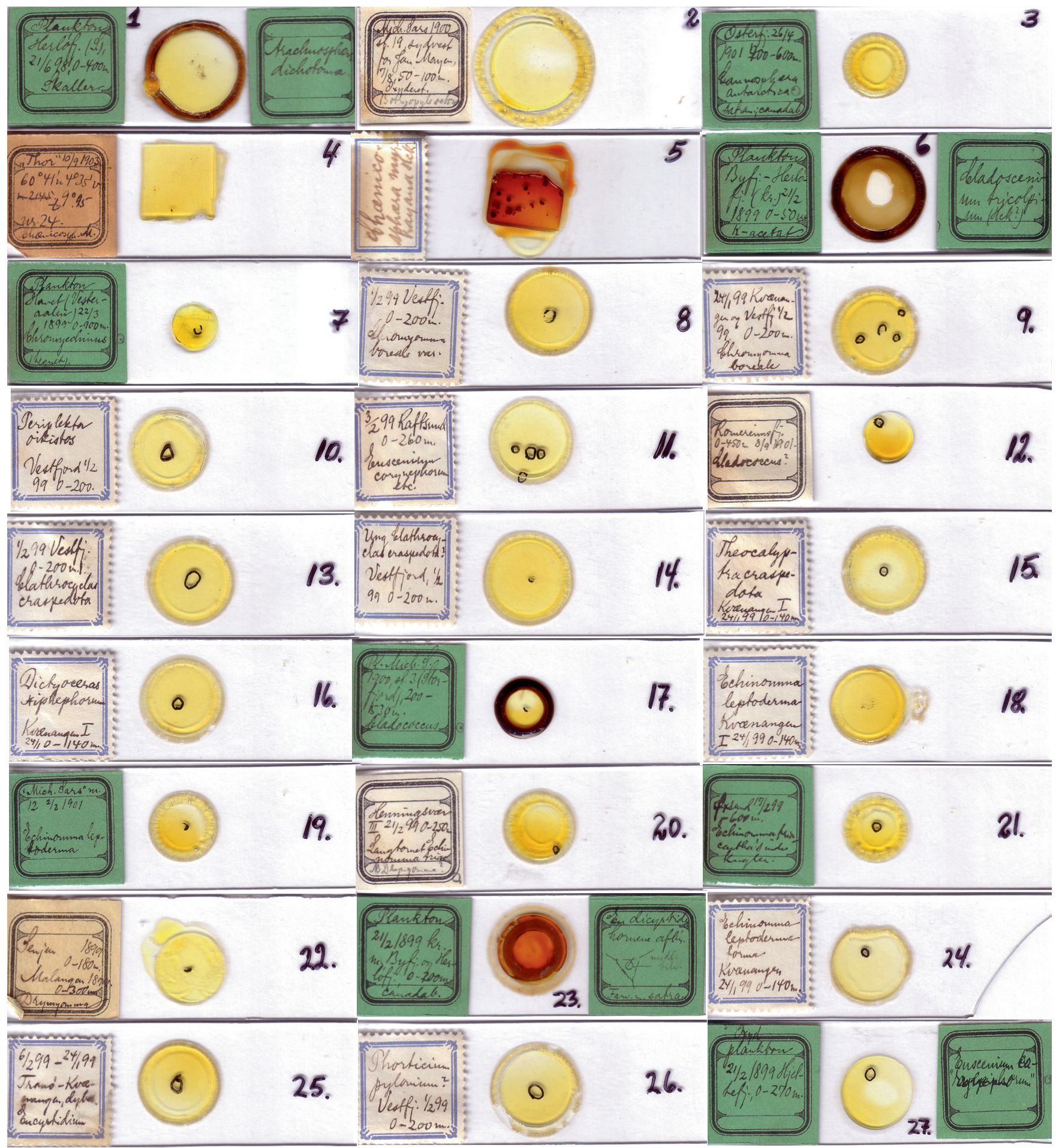

Explanation of Plate 8. Slides in the Jørgensen radiolarian collection.

this case, it is hardly correct to consider them as the radial spines characteristic of the genus Stylodictya. The above species might just as well, for that matter, be classed as belonging to the genus Porodiscus (without marginal spines); but as one cannot be sure whether there may not be radial spines on the outside ring in the fully developed individual, I have retained the species under the genus Stylodictya, where it would at once be placed after a less critical examination. It is certainly also closely related to the following species $[S$. validispina $]$.
In structure it is very like Porodiscus orbiculatus HCK. (L. 86 [1887], p. 492, pl. 29, fig. 1), which, however, wants the very characteristic, coarsely porous, central part. This has the appearance of a spherical shell with a diameter greater than the breadth of the disc, with a smaller sphere in the middle (this sphere is the innermost shell) and with equatorial rings outside. Only twice noticed in 1899: In the sea off Gaukværö, 19/1, 0-700 m; in the sea off Röst, 22/3, 0-900 m. This makes it very probable that it is an oceanic, deep water species, which only exceptionally comes to our coasts. 


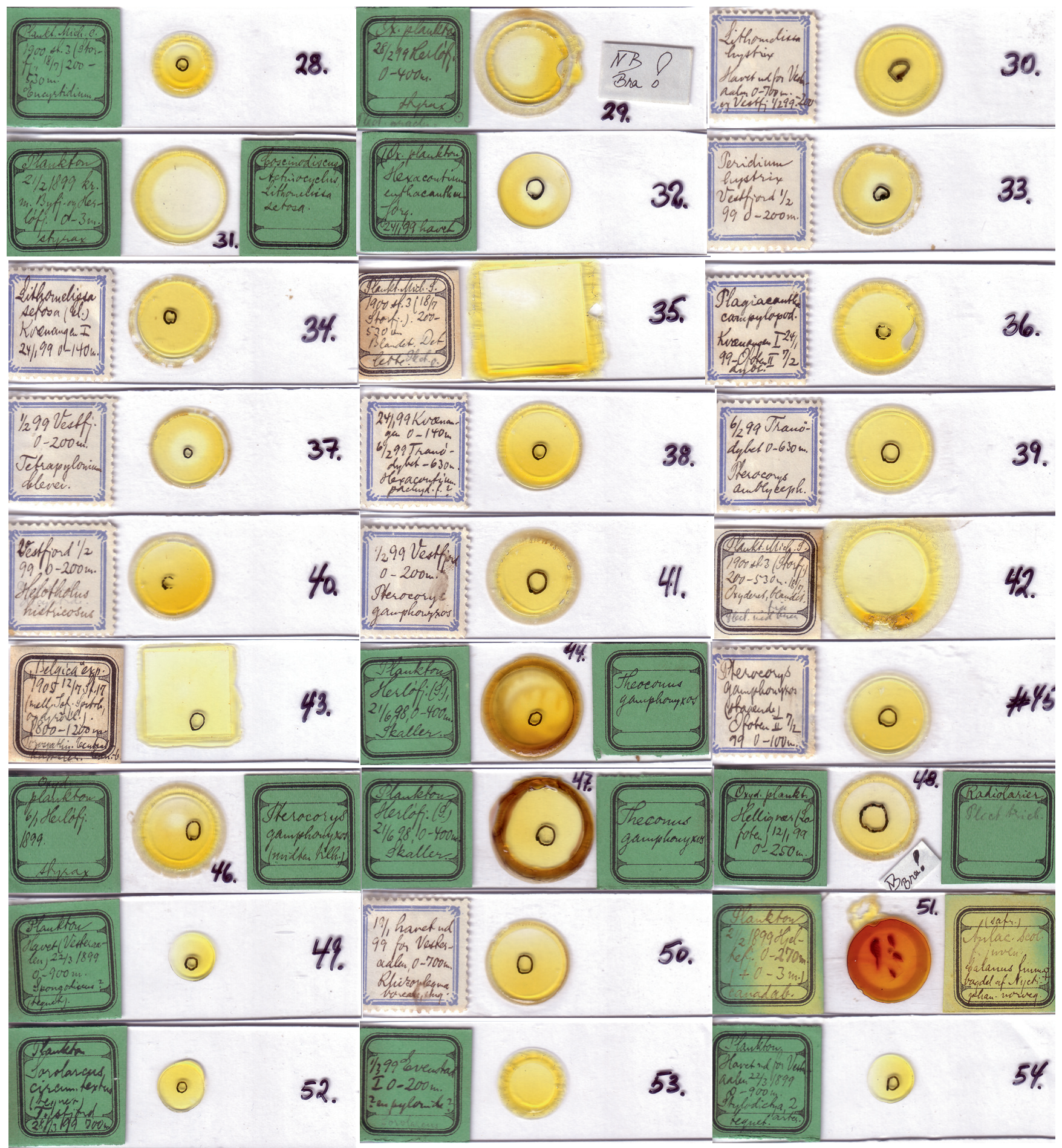

Explanation of Plate 9. Slides in the Jørgensen radiolarian collection.

Lectotype. PMO224.465; Plate 3, fig. 6a; Slide \#54 (N37/0). Plate 3, fig. 6b, c original drawings by Jørgensen (1905, fig. 39a and $b$, respectively).

Remarks. Stylodictya tenuispina is, as for the other Stylodictya species, characterized by a small inner medullary shell, which is connected to the inner ring by four radial beams, giving the inner ring a square outline. See remarks for S. validispina. Stylodictya tenuispina Jørgensen is regarded as the correct formal name.

Stylodictya validispina Jørgensen, 1905

(Pl. 3, fig. 7a, b)

1905 Stylodictya validispina Jørgensen: 119; pl. 10, fig. 40a, b. 


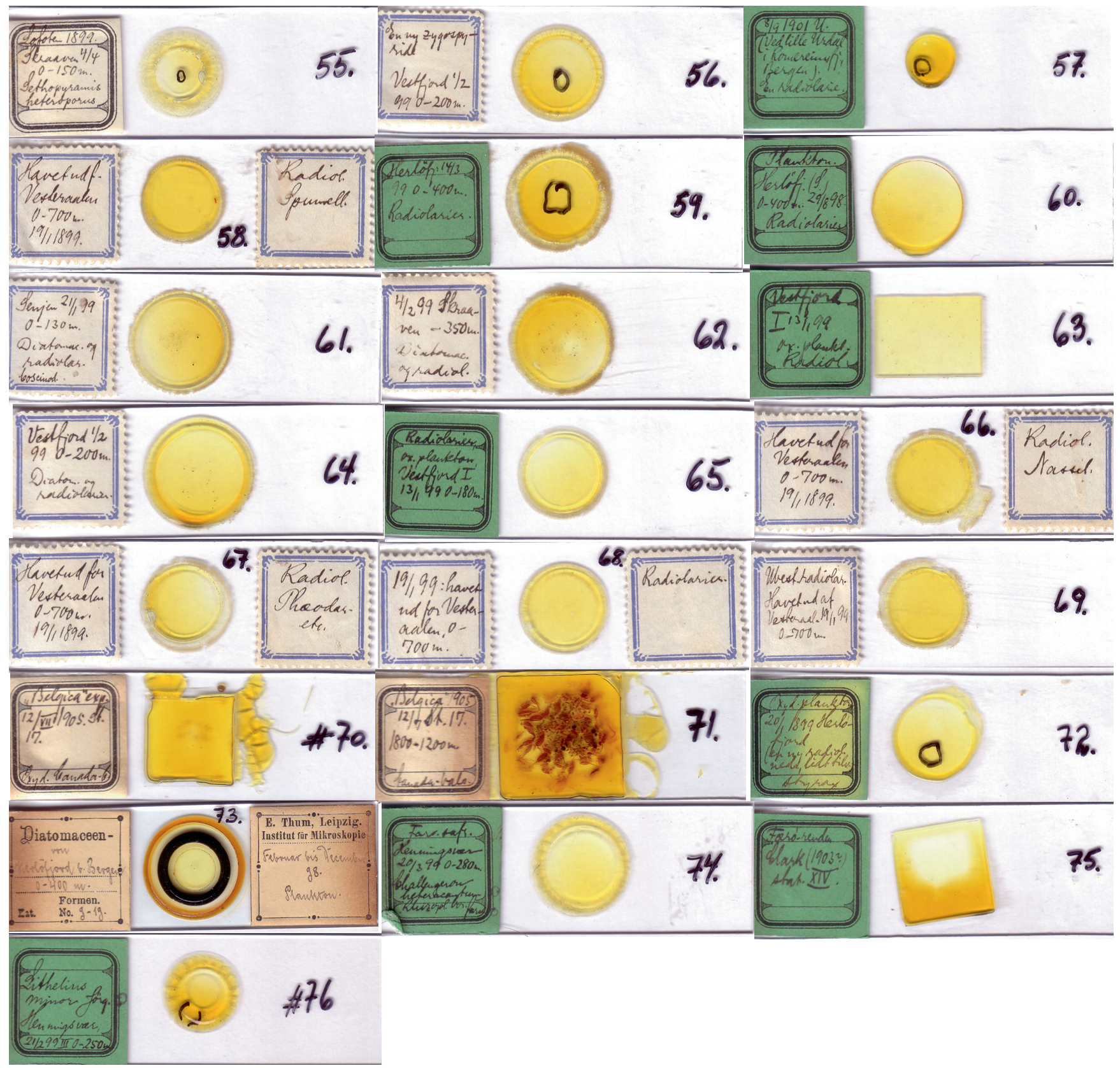

Explanation of Plate 10. Slides in the Jørgensen radiolarian collection.

\section{Original description (Jørgensen, 1905)}

The structure is, on the whole, the same as in the foregoing species $[S$. tenuispina]. The strange, peculiar, strongly convex central part is, however, wanting (the disc is homogeneous) and the margin is furnished with numerous strong spines which are almost regularly distributed. Shape of the shell in side view: Broadly linear (the disc is of almost even thickness) but little narrower at the margin than in the middle, with sharp or obtuse corners, not clearly rounded off at the ends, but almost square. There are short spines scattered on the central part. The system of rings: From the innermost little shell 4 radial rods extend in the shape of a cross to the first ring, as in the preceding species $[S$. tenuispina]. The ring itself is also here an irregular quadrangle with rounded corners. Outside this ring, there are three others, connected to each other by radial rods whose number increases outwards. In the prolongation of the 4 primary radial rods (from the inmost shell) may be seen, more or less clearly, some similar ones which are rather crookedly placed, and these conjoin to form 4 , more or less definite, zigzag rods, which go through the whole system of rings. On the outside ring there are numerous (21) equatorial, narrowly conical, marginal spines. Pores: The pores in the centre are very small, punctiform, very scattered with wide intermediate spaces, gradually larger outwards, on the two outer rings about 2 on the space between the rings, uneven in size, up to $4 \mu$ or a little larger. Between the pores on the central part very small, punctiform byspines are scattered, which may easily be overlooked. Radial spines: Numerous, narrowly conical (subulate), strong radial spines of different lengths, the longest being little more than $1 / 2$ of the radius of the disc. Some project out from the ring next to the outside one, several too 
from the one next to the inmost one, and yet a few from the innermost one. Byspines: A few scattered ones, very short and very small, needle shaped, extend from the central part of the disc. Dimensions: The diameter of the inner shell $14 \mu$, of the first ring $34 \mu$, of the second $60 \mu$, of the third $84 \mu$, of the fourth $102 \mu$. In thickness $24 \mu$. The specimen illustrated appears to be almost fully developed. Probably only the small portion of the outer ring which is not seen in the illustration, is all that is wanting. This species exhibits a certain amount of agreement with $S$. stellata BAIL., which has, however, fewer and broader spines, and also differs in other respects. Only once found: Sea off Röst, 22/3 1899, 0-900m. (together with the preceding and the following species [S. tenuispina, S. aculeata]).

Lectotype. PMO224.466; Plate 3, fig. 7a; Slide \#54 (M37/0). Plate 3, fig. 7b original drawing by Jørgensen (1905, fig. 40a).

Remarks. Jørgensen described four species in the genus Stylodictya. S. aspera was described in 1900 based on one individual. In 1905 he described and figured the remaining three $(S$. aculeata, S. tenuispina and S. validispina). We have found the types (lectotypes) of the latter two, but not of $S$. aspera and $S$. aculeata. As many have commented (Jørgensen, 1905; Petrushevskaya, 1968), S. aculeata and S. validispina seem to be very similar, differing only by the marginal spines (both radial spines and byspines). In $S$. validispina the radial spines are distributed in the equatorial plane and the byspines are distributed mainly in the central part of the disc. In $S$. aculeata the radial spines are more irregularly placed, protruding not only in the equatorial plane but being dispersed over the broad, rounded margin of the disc, while the byspines are more scattered and distributed over the whole of the disc nearly to the margin. Jørgensen also mentioned the similarity between $S$. validispina and S. stellata Bailey, 1856, but this was rejected by Nigrini \& Moore (1979) due to the absence of 'the characteristic central girdles'. Itaki \& Bjørklund (2006) provided photographs of Bailey's type material (i.e. the lectotype) clarifying the central part, confirming the strong similarity between $S$. validispina and S. stellata. They concluded that the two latter species were identical and, therefore, S. stellata Bailey, 1856 has priority. Thus, Stylodictya stellata Bailey, 1856 is regarded as the correct valid name. The lectotype designated in this paper is Jørgensen's lectotype for what he believed to be a new species and not the lectotype for $S$. stellata.

Tetrapyle polyacantha Jørgensen, 1900 (No illustration)

1900 Tetrapyle polyacantha Jørgensen: 63 (not figured).

Original description (Jørgensen, 1900)

Die äussere Schale (zweites Gürtelsystem) ellipsoidisch, mit ein wenig unregelmässigem, schwach rhombischem Umriss. Länge $0,047 \mathrm{~mm}$., Breite 0,045 . Poren hexagonal-rundlich oder etwas oval, $0,003-0,005 \mathrm{~mm}$. breit. Das erste Gürtelsystem $0,025 \mathrm{~mm}$. lang, 0,021 breit. 4 grössere Radialstacheln, zwei polare, zwei aequatoriale, bis $0,052 \mathrm{~mm}$. (mehr als d. Durchmesser) hervorragend, im distalen Ende sehr fein ausgezogen (wie auch die anderen Stacheln). Zahlreiche (30 bis 40) kleinere lange, nadelförmige Radialstacheln, 0,020 bis $0,030 \mathrm{~mm}$. hervorragend. Nur wenige Individuen gefunden: Novbr. - Decbr.

Types. Not defined.

Remarks. Few individuals were reported and no illustration(s) provided by Jørgensen. We have not observed any specimens fitting this description. This species might be a juvenile form of Tetrapylonium clevei.
Tetrapylonium clevei Jørgensen, 1900

(No illustration)

non 1887 Phorticium pylonium Haeckel: 709; pl. 49, fig. 10.

1899 Phorticium pylonium Haeckel; Cleve: 31; pl. 3, fig. 2a, b (non c).

1900 Tetrapylonium clevei Jørgensen: 64 (not figured).

1905 Phorticium pylonium Haeckel; Jørgensen: 120; pl. 10, fig. $42 \mathrm{a}-\mathrm{d}$, pl. 11, figs $42-45$.

\section{Original description (Jørgensen, 1900)}

Aeussere Schale im Umriss subrectangulär oder subquadratisch, $0,125 \mathrm{~mm}$. lang und fast ebenso breit, mit 2 Gürteln. Poren unregelmässig rundlich, sehr ungleich gross, 0,004 bis $0,010 \mathrm{~mm}$. breit; Wandstärke ungefähr $0,003 \mathrm{~mm}$. Zahlreiche nadelförmige Nebenstacheln, bis $0,025 \mathrm{~mm}$. lang.

Mittlere Schale ellipsoidisch, 0,062 mm. lang, 0,052 breit, durch 15 bis 20 starke Radialbalken mit der äusseren verbunden. Poren unregelmässig und ungleich.

Innerstes Gürtelsystem ellipsoidisch, 0,037 mm. lang, 0,028 breit.

Wie bei Octopyle und verwandten Gattungen ist die äussere Schale häufig unregelmässig ausgebildet. Man findet aber immer die zwei Gürtel sammt den vier grossen Löchern.

Selten: Mai, Juli-August, Oktbr.-Novbr.

Types. Not defined.

Remarks. Tetrapylonium clevei was erected by Jørgensen (1900, p. 64) and kept separated from Haeckel's Phorticium pylonium. Jørgensen himself rejected the name T. clevei in 1905 (p. 120) and made it a synonym of Phorticium pylonium Haeckel, 1887. However, Jørgensen (1905) stated that due to the vagueness of Haeckel's description of $P$. pylonium, he could not make a final decision on this species until Haeckel's species had been more clearly defined.

There was also a discussion between Jørgensen and Cleve about this species. Cleve (1899) listed P. pylonium from the waters of Spitsbergen, while Jørgensen (1900) described it as T. clevei from the fjords off Bergen. Later, Jørgensen (1905, p. 120) wrote: 'Cleve has, in a later work accepted this name [T. clevei] and remarks that the species is not identical to Phorticium pylonium'. Petrushevskaya later moved T. clevei into the genus Phorticium and states (1968, p. 59): "There is no doubt that they should be differentiated as two distinct, although similar, species; Ph. pylonium, distributed in the tropical regions and $P h$. clevei (Jörgensen), encountered in the boreal and polar regions'. We now agree with this observation, although we have in our previous papers, dealing with the Norwegian Sea, used both names (Phorticium clevei and Phorticium pylonium) for the same species. However, when comparing the tropical forms of P. pylonium with Norwegian Sea forms, they are different. There are also some indications that the species concept $P$. clevei consists of two varieties (Kruglikova pers. comm.), but we will not go into that discussion here until more documentation has been gathered. At present, we agree with Petrushevskaya that $T$. clevei belongs to the genus Phorticium. We therefore believe the correct formal name to be Phorticium clevei (Jørgensen, 1900).

\section{Nassellarians}

Androcyclas gamphonycha Jørgensen, 1905 (P1. 4, figs 1-6) 
1900 Pterocorys theoconus Jørgensen: 86.

1900 Pterocorys gamphonyxos Jørgensen: 86.

1900 Pterocorys amblycephalis Jørgensen: 87.

1905 Androcyclas gamphonycha Jørgensen: 139; pl. 17, figs 92-93.

1905 Androcyclas amblycephalis Jørgensen: 139; pl. 17, figs 94-97.

\section{Original description (Jørgensen, 1905)}

Androcyclas (n.gen): The four primary spines and the ventral sagittal one are present. The apical spine, D, runs close to the cephalic wall, and finally protrudes as a marginal topsword, thick and large, and furnished with three broad edges. There is, consequently, no distinct columella. The three basal spines, A, Lr and Ll protrude from the upper part of the thorax (the spine A lowest down) like fine needles, which pierce the wall, no part of them being enclosed in it as "thoracic ribs". The ventral, sagittal spine also protrudes like a similar needle in the region of the neck. There is also a long, inner axial spine, which reaches as far down as to the upper part of the abdomen. Cfr. the remarks about the region of the neck, under the description of the species. I referred the following species previously to the genus Pterocorys HAECKEL, but I now find it necessary to separate it from this genus which has strong side swords on the thorax. On the other hand, there is probably no doubt that the genus Theoconus HAECKEL to some extent corresponds to my genus Androcyclas. Thus, Theoconus jovis HAECKEL L. 86 [1887], pl. 69, f. 4) is undoubtedly of quite the same structure as Androcyclas gamphonycha, the byspines on the abdomen of the latter only excepted. As, however, HAECKEL'S group Theocyrtida, to which Theoconus HAECKEL and Theocalyptra HAECKEL. belong, is defined as Tricyrtida without radial apophyses, I have thought it most practical, to avoid confusion, temporarily to erect the new genus Androcyclas.

Androcyclas gamphonycha (n. sp.): The region of the neck is very peculiar, not forming any distinct stricture between the cephalis and thorax, but a zone where these two joints gradually pass into each other. This region appears on the dorsal side to lie between two pair of branches from the apical spine, D, namely two dorsal, lateral spines below (corresponding to those in the genus Amphimelissa) and the primary, lateral arches above. These dorsal, lateral spines (from the base of the spine A and the spine D) lie near the hind wall of the cephalis. The lower part of the apical spine, $\mathrm{D}$, is here a columella in the region of the neck, but lying near the cephalic wall. The length of the abdomen varies considerably, probably according to age; this is also the case with the number of byspines. It is not unusual to find comparatively well developed forms which are apparently almost or entirely without the characteristic byspines, but which in other respects diverge so little from the typical forms that they can scarcely be considered to belong to any other species. Therefore I now think that Pterocorys theoconus must be looked upon as a form of this species. The other, very short tophorn is very rarely seen distinctly and is probably a more or less accidental formation. Sometimes strong siliceous edgings are developed on the upper part of the cephalis, and these may be protruding and in certain positions look like a very broad, short spine. According to my experience no limit either can be drawn between Pterocorys gamphonyxos and P. amblycephalis. The younger forms seem to answer best to the latter, which is in appearance so different to P. gamphonyxos that it is generally easy to keep them distinct. (This is done in the tables). The principal difference is that $P$. amblycephalis has a cephalis which is at the upper part abruptly cut off and, at the very top, often open. This opening is probably closed later on. The tophorn is generally shorter and more weakly developed and the abdomen short and broad, without distinct byspines, all characteristics which may be explained by supposing that $P$. amblycephalis is the younger stage of development. On individuals which it seemed more correct to refer to $P$. amblycephalis than to $P$. gamphonyxos, I have also occasionally seen short and broad byspines in conjunction with a better development of the abdomen. On the best developed specimens of A. gamphonycha, the abdomen is again narrowed below, the strongest set of spines being on that part which is broadest. The byspines are only slightly bent. Frequent, in Tranødybet 6/4-1899, 0-630 m., numerous, otherwise rather sparse and generally only in deep water. Distribution: On the west coast of Norway, in deep water, rare. Off the coast of Finmark 5/3-1901, in a surface sample (S/S Michael Sars cfr. Gran, 1902, p. 154). Perhaps a temperate oceanic form.

Lectotype. PMO224.467; Plate 4, fig. 1a; Slide \#44 (K38/1). Plate 4, fig. 1b original drawing by Jørgensen (1905, fig. 92).

Paralectotype 1. PMO224.468; Plate 4, fig. 2a; Slide \#45 (K38/3). Plate 4, fig. 2b original drawing by Jørgensen (1905, fig. 93).

Paralectotypes 2 and 3. PMO224.469/1 (left), PMO224.469/2 (right); Plate 4, fig. 3; Slide \#41 (M37/0).

Paralectotype 4. PMO224.470/1; Plate 4, fig. 4; Slide \#39 (O37/2 lower left).

Paralectotype 5. PMO224.470/2; Plate 4, fig. 5; Slide \#39 (O37/2 upper right).

Remarks. In 1900, Jørgensen named three new species of Pterocorys (P. theoconus, P. gamphonyxos and P. amblycephalis). However, in 1905 he synonymized these three with a new species that he erected, i.e. Androcyclas gamphonycha. All of these 'varieties' (except $P$. theoconus) are depicted in Plate 4 herein. Jørgensen (1905, pl. 17, figs 94-97) still depicted A. amblycephalis (= P. amblycephalis), stating that this form was easy to recognize, because of a cephalis with an abrupt, flat and often open top. However, Jørgensen (1905, p. 139), and the present authors, regarded $P$. amblycephalis as a juvenile stage, and $P$. theoconus and $P$. gamphonyxos as different 'forms' of A. gamphonycha. This species has a bipolar distribution. Its taxonomic position is not yet clear. Petrushevskaya (1971, pp. 231-232) listed it under the subfamily Pterocorydina as Lamprocyclas (= Androcyclas) gamphonycha. We have not taken sides in this discussion and retain Jørgensen's taxonomy. Androcyclas gamphonycha Jørgensen is therefore regarded as the correct formal name.

\section{Campylacantha cladophora Jørgensen, 1905}

(P1. 4, figs 7-10)

1905 Campylacantha cladophora Jørgensen: 129; pl. 12, fig. 47a-c.

\section{Original description (Jørgensen, 1905)}

Campylacantha (n. gen.): Has the four primary spines, D, Lr, Ll and A, as well as the ventral, sagittal one, V. The dorsal, sagittal one, D, is bent strongly downwards. The lateral, basal spines, $\mathrm{Lr}$ and $\mathrm{Ll}$, are also bent downwards, being as usual directed half forwards and half sideways (so as to be ventral lateral). The ventral, sagittal spine is rather thin, almost straight, bent strongly downwards and converges distinctly towards the dorsal, basal spine, D.

The principal difference between this and the previous genus lies in the ventral, sagittal spine.

The primary vertical of branches (cfr. The introductory remarks under Nassellaria) appears only on the apical spine which is without any other branches.

Campylacantha cladophora (n. sp.): The sagittal, basal spine is best developed, very strong, long, strongly bent, gradually narrowing off into a long fine point, like all the strong main spines and branches three-edged. One edge is dorsal, the others lateral. On these three edges, there are strong, expanded, narrow pointed branches, several in a row along the same edge, rather scattered and not clearly forming verticils when compared to the 
branches on the other edges. The branches become short towards the end of the main spines. The larger branches are in their turn furnished with similar squarrose branches. The basal, lateral spines are also strongly developed, although not quite so much as the sagittal, dorsal one, in other respects corresponding precisely in form and arrangement of branches. The apical spine is much less developed, having only a verticil of three branches on the corresponding place to the verticil of Plagiacantha, outside this being thin and unbranched. The ventral, sagittal spine is thin and unbranched, almost straight, pointing obliquely downwards between the lateral spines and being somewhat shorter than these. In addition, in well developed forms, there appears to be two strong, lateral arched branches extending from the basal, dorsal spine at the base of the apical spine. These arched branches form a pair of secondary, lateral spines, $1_{\mathrm{r}}$ and $\mathrm{l}_{1}$, in form and arrangement of branches corresponding to the primary, lateral spines, only less developed. In those individuals where a smaller number of secondary spines were developed, they were not visible. But it must be remarked that the species is very brittle, so that the branches are easily broken off. This species is especially interesting, as it seems to show the evolution of the ring species. Cfr. above [general discussion of genus Campylacantha] and under the following species [Dictyocircus clathra$t u s]$. Rare, always in small numbers, only in deeper water samples. Seems to be boreal oceanic. Distribution: Otherwise only observed on the west coast of Norway, The Oster Fiord, very scarce, in deep water.

Lectotype. PMO224.471/1; Plate 4, fig. 7; Slide \#36 (M37/1 upper left).

Paralectotype 1. PMO224.471/2; Plate 4, fig. 8; Slide \#36 (M37/1 middle).

Paralectotype 2. PMO224.471/3; Plate 4, fig. 9; Slide \#36 (M37/1 lower left).

Remarks. The name written on the slide from which we have erected lecto- and paralectotypes is 'Plagiacantha campylopod', a name Jørgensen never used in his publications. Goll (1979) revised this species and moved it to the genus Neosemantis. Neosemantis cladophora (Jørgensen, 1905) is regarded as the correct formal name.

\section{Ceratospyris hyperborea Jørgensen, 1905}

$$
\text { (P1. 4, figs 11-12) }
$$

1905 Ceratospyris hyperborea Jørgensen: 130-131; pl. 13, fig. 49.

\section{Original description (Jørgensen, 1905)}

I have only seen very few individuals of this species. Its structure seems to be of precisely the same type as that of Dictyocircus clathratus, only that, on both sides of the sagittal ring, there is a further development of the net work, which has become two complete domes, one on each side. The primary pores (nearest the sagittal ring) are polygonal, the others being irregular roundish and oblong and varying considerably in size. The separating walls are strong, with here and there narrow, protruding points which form obliquely diverging narrow spines. There is also a rather plentiful number of similar byspines. All the spines are little prominent, to $1 / 4-1 / 2$ of the diameter of the sagittal ring. The species does not appear to be identical to any of Haeckel's. Very rare and only singly: The Vestfjorden 1/2 1899, 0-200 m. Distribution: In warm, salt waters of the Atlantic beyond Søndmøre (S/S Michael Sars, 2/2 1901, between station 4 and 5, in the surface; cfr. Gran, 1902, p. 149), very sparsely; the Oster Fjord near Bergen, at a great depth, here too only singly.

Lectotype. PMO224.472; Plate 4, fig. 11; Slide \#56 (L38/0).

Remarks. Goll (1976) revised this species and made it a subspecies of Lophospyris pentagona (i.e. L. p. hyperborea). Lophospyris pentagona (Ehrenberg, 1872) hyperborea (Jørgensen) is regarded as the correct formal name.

Cladoscenium limbatum Jørgensen, 1905

(P1. 4, fig. 13a, b)

1905 Cladoscenium limbatum Jørgensen: 134-135; pl. 15, fig. 74.

\section{Original description (Jørgensen, 1905)}

Resembles to some extent the foregoing species [C. tricolpium], and is, on the whole, of the same structure, but, is nevertheless, quite different through the following special characteristics: The main spines are more broadly three-edged, each edge having 2-4 diverging spines, which nearest to the shell are often prolongated to arch-shaped fine, supporting branches, between the shell and the main spine. Such arches are only seen from the one or two innermost branches (spines) and most clearly on the upper side of the main spines. Outside the basal arches, perhaps only between the lateral spines, a brim-shaped continuation of the lattice shell is developed. This brim continues a little way forwards along the side of the main spines. There is a verticil of branches high up on the columella, as in the foregoing species, but these branches are here almost straight on the distance between the columella and the shell. The network of the lattice shell is much more perfect than in the foregoing species, most of the meshes being small and more or less distinctly square. There is a trace of lattice wings from the top horn to the basal spines, and for this reason the species, perhaps, should most correctly be referred to the genus Pteroscenium HCK. The cephalis is $52 \mu$ in height, the width between the lateral spines $56 \mu$. The right, lateral spine is $68 \mu$ in length outside the shell, the tophorn $50 \mu$. The stronger, primary arches seem here to become less conspicuous with growing age, so as to make the network more even in development. Finally the pores seem to disappear, being closed by thin plates, so that they are transformed into windows, not openings. Only two specimens observed: 19/1 1899, 40 miles NW of Gaukværø, 0-700 m.

Lectotype. PMO224.473; Plate 4, fig. 13a; Slide \#66 (L38/0). Plate 4, fig. 13b original drawing by Jørgensen (1905, fig. 74).

Remarks. This species is very rare and differs from Cladoscenium tricolpium in having straight legs, but most characteristic are the diverging spines, which nearest to the shell are often elongated to arch-shaped fine, supporting branches, between the shell and the main spines. Petrushevskaya (1971, p. 71) emended the genus Clathromitra and stated that Cladoscenium tricolpium (Haeckel, 1887) should be transferred to this genus. So should possibly also Cladoscenium limbatum, but for now we regard Cladoscenium limbatum Jørgensen as the correct formal name.

\section{Clathrocyclas craspedota (Jørgensen, 1900)}

$$
\text { (P1. 5, figs 1-6) }
$$

1900 Theocalyptra craspedota Jørgensen: 85 (not figured).

1905 Clathrocyclas craspedota (Jørgensen, 1900); Jørgensen: 139-140; pl. 17, figs 98, 99a, b, 100a-d.

\section{Original description (Jørgensen, 1905)}

The abdomen is a narrow, flat, projecting brim, on well developed specimens having two or three regular, circular rows of meshes, the inner row with small pores. The free side-walls of a ring of meshes under development will have the appearance of a regular circle of short, radial spines on the abdominal brim. The same spines are present as in the preceding genus [Androcyclas gamphonycha]. The three basal spines protrude similarly as fine needles in the upper part of the thorax (the dorsal spine, A, farther down than the others). The apical spine, D, also here protrudes with a broad three-edged topsword directed upwards and somewhat backwards. The ventral, sagittal spine protrudes upwards and forwards (ventrally) with a similar, three-edged topsword, which is, however, a little 
smaller and points obliquely forwards. Refer for further details to Jørgensen, 1. C. [1900]. As the incompletely developed abdomen often exhibits a marginal brim of regular, short spines like those Haeckel draws for species of the genus Clathrocyclas, subgenus Clathrocycloma HCK. (L. 86 [1887], pls. 58, 59), I have thought it best to refer my species to this genus where it seems to have its natural place. In doing so, I also think that Clathrocycloma HCK. will be found to have the three basal spines protruding from the upper part of the thorax like fine needles. If these needles are overlooked or absent, and no notice is taken of the spines on the brim of the abdomen, the species according to Haeckel's system will be a Theocalyptra. Halicalyptra $?$ cornuta Bail. = Theocalyptra c. Haeckel is quite impossible to determine from the very imperfect illustration, given by Bailey. After this drawing it has only cephalis and thorax. Frequent, though never numerous. Distribution: On the west coast of Norway, very rare. In surface samples 2/2 1901, off Sundmøre, and 13/2 off Lofoten (cfr. Above under Cladoscenium tricolpium p. 134). If this species be Cleve's Theocalyptra cornuta, it has been found at great depths at some places in the North Atlantic right up to the north west coast of Spitzbergen, and at scattered places in the western part of the North Atlantic. Most probably boreal oceanic.

Lectotype: PMO224.474; Plate 5, fig. 1; Slide \#66 (L40/0).

Paralectotype 1. PMO224.475/1; Plate 5, fig. 2; Slide \# 13 (M35/2).

Paralectotype 2. PMO224.475/2; Plate 5, fig. 3; Slide \# 13 (M35/0).

Paralectotype 3. PMO224.475/3; Plate 5, fig. 4; Slide \# 13 (M35/3).

Remarks. The species was recombined as Corocalyptra craspedota by Schröder (1914, pp. 122-123, figs 87-90). Petrushevskaya (1971, p. 222) later emended the genus Eucecryphalus to also include the genus Corocalyptra. In Boltovskoy et al. (2010) Corocalyptra craspedota was synonymized with several other Theoperidae species, e.g. Corocalyptra cervus (Ehrenberg, 1872), Eucecryphalus gegenbauri (Haeckel, 1860), Clathrocyclas danaes Haeckel, 1887, Lampromitra danaes (Haeckel, 1887), these authors pointing out that this is a heterogeneous group. Until further taxonomic work has been done to clarify the true number of species in this group we consider Corocalyptra craspedota (Jørgensen, 1900) as an accepted name.

\section{Dictyoceras acanthicum Jørgensen, 1900} (No illustration)

1900 Dictyoceras acanthicum Jørgensen: 84 (not figured).

1905 Dictyoceras acanthicum Jørgensen: Jørgensen; 140; pl. 17, fig. $101 \mathrm{a}$, pl. 18 , fig. $101 \mathrm{~b}$.

\section{Original description (Jørgensen, 1900)}

Cephalis fast kugelförmig, mit fünf ziemlich dünnen, cylindrischen, stark divergirenden Hörnern versehen, die 1- bis 2-mal so lang wie der Durchmesser des Cephalis sind. Durchmesser ungefähr $0,028 \mathrm{~mm}$. Poren klein, rundlich, dickwandig. Thorax kegelig glockenförmig, unten am breitesten, hier $0,091 \mathrm{~mm}$. breit, 0,075 $\mathrm{mm}$. hoch, mit rundlichen, etwas unregelmässigen, ziemlich dickwandigen Poren. Drei auslaufende Radialstacheln, die den Thorax in verschiedener Höhe ungefähr an der Mitte bis dicht vor dem unteren Rand desselben durchbohren, an der Aussenseite der Schaale durch einen deutlichen, aber nicht grossen verticalen Gitterflügel gestüzt, mit ihrem freien, cylindrischen Theil ungefähr $0,030 \mathrm{~mm}$. über die Gitterschaale hervorragend. Grosse, nadelförmige, rechtwinklig zur Schaalenoberfläche gestellte Nebenstacheln an dem oberen Theil des Thorax und der Radialstacheln.
Abdomen kurz, glockenförmig, gegen die untere Oeffnung etwas erweitert, $0,020 \mathrm{~mm}$. hoch, mit Poren, die denen des Thorax ähneln, nur ein wenig grösser sind $(0,006 \mathrm{~mm}$. breit).

Sehr selten: April, August, Oktbr. - Novbr.

\section{Original description (Jørgensen, 1905)}

It appears very doubtful whether this species really is specifically different from the following one $[D$. xiphephorum $]$.

The only difference appears to be in the protruding basal spines, which in this species are little more strongly developed outside than inside the lattice shell, while they are transformed into three-edged swords in D. xiphephorum. I retain, however, D. acanthicum preliminarily as a separate species, as it is, generally speaking, easy to keep distinct from $D$. xiphephorum. If they should prove to belong to the same species, D. acanthicum would be the younger stage.

Rather rare, always in deep water samples, sparse.

Distribution: On the west coast of Norway rare. In surface samples 13/2 1901, off Lofoten, and 5/3 off Finmarken (S/S Michael Sars, cfr. above).

Types. Not defined.

Remarks. No types have been observed of this species in Jørgensen's radiolarian slide collection. Jørgensen did not compare his two Dictyoceras species to D. virchowii Haeckel (1860, pl. 8, figs $1-5$ ). To us $D$. virchowii is rather similar to $D$. acanthicum, but differs in having fewer cephalic needle-shaped spines. D. acanthicum might actually be a juvenile stage of Dictyoceras xiphephorum (see the following species). We have observed both of Jørgensen's forms in our fjord plankton and sediment material, but they are extremely rare. Whether the two are different growth stages of $D$. xiphephorum or two different species cannot be settled herein with certainty, but because they are so rare we believe it better to synonymize the two. See $D$. xiphephorum for more discussion.

\section{Dictyoceras xiphephorum Jørgensen, 1900}

(P1. 5, figs 7-8)

1899 Pterocorys irregularis Cleve: 32; pl. 4, fig. 1.

1900 Dictyoceras xiphephorum Jørgensen: 84-85; pl. 5, fig. 25.

1905 Dictyoceras xiphephorum Jørgensen: Jørgensen; 140 (not figured).

1973 Lipmanella irregularis (Cleve): Dumitrica; 840; pl. 25, fig. 2.

\section{Original description (Jørgensen, 1900)}

Cephalis fast kugelig, Durchmesser 0,029 mm., mit kleinen, rundlichen, dickwandigen Poren und 6 bis 7 (oder mehr?) dünnen cylindrischen, stark divergirenden Hörnern, die $1 \frac{1}{2}$ - bis 2-mal so lang wie der Durchmesser des Cephalis sind. Thorax $0,069 \mathrm{~mm}$. hoch, glockenförmig, unsymmetrisch, mit ungleich grossen, unregelmässig rundlichen, ziemlich dickwandigen Poren, die nach unten zu nur wenig grösser werden. Unterer Durchmesser des Thorax $0,100 \mathrm{~mm}$. An der Seite des Thorax finden sich drei, stark nach der Seite ausgezogene Seitenflügel, die mit einem breiten, dreischneidigen, schwertförmigen, etwas aufgerichteten Stachel endigen, der $0,036 \mathrm{~mm}$. lang, 0,010 breit ist. Ausserdem finden sich am oberen Theile des Thorax einige sehr lange, nadelförmige Stacheln, die senkrecht von der Oberfläche abstehen. Abdomen kurz und breit glockenförmig, $0,021 \mathrm{~mm}$. hoch, unten verbreitert, mit unregelmässigen, rundlichen, gegen den Saum viel grösser werdenden und sehr dünnwandigen Poren. Sehr selten: Hjeltefjord, 21/11 1898, in einer Tiefseeprobe.

Lectotype. PMO224.476; Plate 5, fig. 7; Slide \#16 (M39/3). 
Remarks. Jørgensen's lectotype (Pl. 5, fig. 7) was found on Jørgensen's slide \#16. This slide contains only one individual and Jørgensen marked this slide Dictyoceras xiphephorum. However, this specimen resembles very much the illustrated specimen from 1905 (see Jørgensen, 1905, pl. 18, fig. 101b = Pl. 5, fig. 8 herein) which he named Dictyoceras acanthicum. We agree, as suggested by Jørgensen (1905), that $D$. acanthicum is a juvenile stage of $D$. xiphephorum. Note also Cleve (1899, pl. 4, fig. 1) who described Pterocorys irregularis. This specimen is partly fragmented, most spines broken off, definitely not a complete skeleton. Due to the large similarities we believe Jørgensen's Dictyoceras xiphephorum to be the same as Cleve's Pterocorys irregularis (Bjørklund et al. 2014). P. irregularis was emended to Lipmanella irregularis by Dumitrica (1973). The latter is therefore regarded as the correct formal name. The lectotype designated in this paper is Jørgensen's specimen for what he believed to be a new species and not the lectotype for L. irregularis (Cleve, 1899).

\section{Dictyocircus clathratus Jørgensen, 1905 (No illustration)}

1905 Dictyocircus clathratus Jørgensen: 130; pl. 13, fig. 48a-e.

\section{Original description (Jørgensen, 1905)}

Dictyocircus (n. gen.): A strong, sagittal ring, one side, the dorsal, being less bent than the other, the ventral. (This peculiarity of the ring species is also mentioned by HAECKEL). This ring is in the following description supposed to be placed downwards, not upwards as by HAECKEL.

On the dorsal side of the ring, there is a long spine, pointing obliquely backwards and upwards, the apical spine, A, in the plane of the ring. On both sides of this apical spine, there are two large, pentagonal meshes, diverging at right angle on each side, both in the same plane perpendicular to the plane of the ring. These are the right and left transverse meshes, ar and a1. These meshes are again both in a dorsal and ventral direction joined to two similar pairs of meshes, the dorsal lateral meshes, fr and f1, situated in a dorsal direction from the transverse meshes, and the ventral, lateral meshes, br and b1. These lateral meshes point obliquely outwards from the plane of the ring. They are thus not in pairs in the same plane, but the plane of the right one forms an angle with that of the left one, both being turned from a position perpendicular to the plane of the ring in a direction away from the centre (fig. IX). In a ventral direction from the pair of meshes b, 3-4 more or less complete pairs of meshes follow, c to e; in a dorsal direction, however, there are only three protruding spines, $g$, the middle one being in the plane of the ring, the other two pointing obliquely outwards and downwards. Similar protruding spines are found, at several points (cfr. the description of the species). Although I am but imperfectly acquainted with this form, having only seen a couple of individuals, I have endeavoured to trace its structure as completely as possible, as it is a very interesting form, which seems, to be well suited to throw light upon the connection between the ring forms of Nassellaria and the group Plectoidea HAECKEL on the one hand and the group Zygospyrida HAECKEL on the other. The connection with the latter seems to me to be quite evident, leaving scarcely no doubt that such forms as Ceratospyris are evolved from a ring like Dictyocircus with a further development of meshes on both sides outside those described, until there is on either side formed a closed network. The conspicuous narrowing in Ceratospyris at the sagittal ring corresponds very beautifully to the right and left meshes which extend forwards from the ring, e.g. in the pair of meshes $b$ and $f$.

The connection with the group Plectoidea is less clear. On this point, however, the genus Campylacantha seems to furnish valuable information. As above mentioned, I consider the sagittal ring to be formed by the connection of the dorsal and ventral sagittal spines (or of meeting branches). Further, I consider the branches hr, h1 between the meshes a and $\mathrm{b}$ to correspond to the ventral, lateral spines in Campylacantha, and the branches ir, il between the meshes a and $\mathrm{f}$ to correspond to the dorsal, lateral ones. In this way too, the large transverse meshes a, diverging at right angles, situated between the dorsal and ventral lateral spines in Campylacantha, are explained, as well as the centrifugally directed pair of meshes $b$ and $f$, formed by the partly forward pointing ventral, lateral spines, and the partly backward pointing dorsal, lateral ones.

Dictyocircus clathratus (n. sp.): To the description above, I will add the following, which applies to the individual illustrated: After the pair of meshes a and $b$, there follows in the same direction (ventrally) two strong, but smaller meshes, c, one on each side. In the corner between b1 and c1, there is a secondary, smaller mesh. After $\mathrm{cl}$, there follows yet another mesh, $\mathrm{d} 1$, while the corresponding one on the right side is wanting, but there is a trace of it in the shape of a protruding spine. (This mesh is probably developed in elder individuals). Then comes a pair of strong, obliquely diverging spines, $\mathrm{k}$, and then two similar ones, $\mathrm{g}$, with an intermediate one in the plane of the ring, which spine might be considered to be the protruding point of the primary dorsal (basal, sagittal) spine. Following this bundle of three spines there are, in the same direction, the two large meshes $f$, which again stretch up to the pair of meshes a. On the stronger branches, there are several protruding spines, which generally point obliquely outwards from the plane of the sagittal ring, in a direction away from the centre. Besides these, there are three spines protruding in the plane of the ring, the apical spine, the protruding, dorsal, basal, sagittal one at $\mathrm{g}$, and the protruding, ventral, sagittal one between the meshes $\mathrm{b}$ and $\mathrm{c}$ (broken off on the specimen illustrated). In addition to these, we have some secondary spines, as for instance the conspicuous twins on the outer side of a1. The two meshes br and b1, are connected by an arched (ventral) beam which is bent outwards, and carries in the middle a rather strong, secondary spine pointing outwards. The sagittal ring and all the stronger branches and spines are three edged. The diameter of the ring is about $50 \mu$.

The individual described was probably not fully developed. Judging from the many surprises which have met me with regard to imperfectly developed radiolaria, I cannot but remark that it is perhaps not altogether impossible that the Dictyocircus clathratus, here described, is a young form of Ceratospyris or a similar species of the group Zygospyrida. This species does not answer well to HAECKEL'S system, so I have been obliged to classify it as a separate genus. It would have had to be classed as belonging to the group Semantida HAECKEL, in which there are species which in structure in important respects undoubtedly agree very well with the species here described. It especially answers well to the genera Semantidium HAECKEL and Semantiscus HAECKEL, both of these having the three large pairs of meshes corresponding to $a, b$ and $f$. These genera have, however, not the long apical spine. Very rare and only singly: Henningsvær, 20/3 1899, 0-280 m.

Types. Not defined.

Remarks. We have not observed this species in Jørgensen's slides. Jørgensen (1905) stated that this species could probably be a juvenile form of Ceratospyris (i.e. hyperborea). However, based on the detailed description given by Jørgensen (1905), Petrushevskaya (1971) during her revision of the suborder Spyrida, found no reason to revise the genus Dictyocircus and accepted it along with Ceratospyris. We therefore conclude that the characters given by Jørgensen qualify Dictyocircus clathratus as a valid species. This species is very rare, and only once has KRB observed a specimen that could be assigned to this species. Dictyocircus clathratus Jørgensen is at present regarded as the correct formal name.

Dictyophimus clevei Jørgensen, 1900

(Pl. 5, figs 9-11) 
non Dictyophimus gracilipes Bailey, 1856: 4; pl. 1, fig. 8. 1899 Dictyophimus gracilipes Bailey, 1856; Cleve: 29; pl. 2, fig. 2. 1900 Dictyophimus clevei Jørgensen: 80; pl. 5, fig. 26.

1905 Dictyophimus clevei Jørgensen; Jørgensen: 138 (not figured).

\section{Original description (Jørgensen, 1900)}

Cephalis halbkugelförmig, $0,013 \mathrm{~mm}$. hoch, 0,025 breit, mit ziemlich grossen, dickwandigen, etwas eckigen Poren und einem kräftigen, dreisehneidigen Apicalhorn, das mehrere Male so lang wie der Cephalis ist. Länge des Hornes 0,097 mm., Breite 0,007 (so breit wie eine Pore). Thorax breit glockenförmig, $0,058 \mathrm{~mm}$. hoch, unten 0,085 breit. Poren unregelmässig rundlich, sehr ungleich gross. Basalstacheln (3) lang, in flachem Bogen zurückgekrümmt, dreischneidig, ungefähr so gross wie das Apicalhorn, von einem gemeinsamen Anfangspunkt innerhalb der Gitterschaale etwas unterhalb des Halssaumes entspringend. Der untere Saum des Thorax mit kleinen, nach unten gerichteten, Dornen versehen, 2 bis 3 oder mehr zwischen je zwei Basalstacheln. Es findet sich auch ein secundärer Mittelstachel, schräg nach oben auslaufend, der schwächer als die Hauptstacheln ist. Die Art CLEVE's scheint nach der Figur dieselbe wie die meinige zu sein. Gestalt und Dimensionen sind sehr zutreffend. Da die BAILEY'sche, übrigens sehr ähnliche, Art durch dünneres und viel kürzeres Apicalhorn abweicht (der Fundort Kamtschatka scheint auch viel zu entfernt gelegen um eine Stütze der Annahme der Identität beider Formen bilden zu können), habe ich mir erlaubt, diese schöne Art nach dem hochverdienten schwedischen Forscher zu nennen, der als der Vater des Studiums des Phytoplankton anzusehen ist.

Sehr selten, in Tiefseeproben: April, August, November.

\section{Original description (Jørgensen, 1905)}

The protruding part of all five spines of uniform breadth, much broader than the inside part, with three distinct edges. In young specimens, the three basal spines extend from the lower part of the thorax. They are partly running in the thorax, but on older individuals always appear to protrude above the free brim.

The irregular, small spines on the free brim of the thorax are here, as in the preceding species [Dictyophimus histricosus], only temporary formations, which later on become intermediate walls between new meshes.

In the passage from the cephalis to the thorax, there are three distinct swellings, two lateral, outside the primary, lateral arches $(\mathrm{Br}$ and $\mathrm{Bl}$ as well as a ventral one between the primary, lateral spines.

The thorax is wide, flatly campanulate.

Dictyophimus gracilipes BAILEY (L. 9 [1856], p. 4, pl. 1, f. 8) does not appear from the description to be this species ("triquetrous; three acute ridges prolonged into long acute basal spines").

Rare, in deep water samples.

Distribution: Rare on the west coast of Norway. CLEVE mention D. gracilipes from a few places in the northern part of the Atlantic up to the northwest point of Spitzbergen, at the most northern places only in deep water. BAILEY'S species was found in the Northern Pacific and Kamtschatka.

Probably boreal oceanic.

Lectotype. PMO224.477; Plate 5, fig. 9; Slide \#66 (K38/4).

Paralectotype. PMO224.478; Plate 5, fig. 10; Slide \#67 (O40/0).

Remarks. Jørgensen (1900, p. 80) was aware of Bailey's (1856) species Dictyophimus gracilipes, but did not believe it to be the same as Dictyophimus clevei. He also refers to the D. gracilipes in Cleve (1899) and notes that these specimens are similar to those he described as D. clevei, stating: '.. habe ich mir erlaubt, diese schöne Art nach dem hochverdienten schwedischen Forscher zu nennen, der als Vater des Studiums des Phytoplankton anzusehen ist' ['... I have permitted myself, to name this beautiful species in honour of the highly deserving Swedish scientist, who is to be regarded as the father of phytoplankton studies']. Jørgensen stresses the differences between juvenile and adult specimens of this species, by the length and position of the three basal feet. $D$. clevei can be recognized in the northern Atlantic waters by its long and slender apical spine and feet, compared to the North Pacific forms; however, there are many intergrading forms. During observations from the Arctic Ocean and its marginal seas, Bjørklund \& Kruglikova (2003) noticed multiple forms of Dictyophimus (emended Pseudodictyophimus Petrushevskaya, 1971 gen. n.): forms with triangular to cylindrical apical, vertical, dorsal, and the two lateral (Ll and Lr) spines, with an open or a closed thorax, with few or many cephalic spines, etc. Whether these are separate species or just ecological variations of one and the same species is still to be determined. For the time being we are of the opinion that the form with long, triangular-bladed basal skeletal elements (A, V, D, Ll and $\mathrm{Lr}$ spines) is different from $P$. gracilipes. Therefore, Pseudodictyophimus clevei (Jørgensen, 1900) is regarded as the correct formal name.

\section{Dictyophimus histricosus Jørgensen, 1905}

$$
\text { (Pl. 5, figs 12-13) }
$$

1905 Dictyophimus histricosus Jørgensen: 138; pl. 16, fig. 89a, b.

\section{Original description (Jørgensen, 1905)}

Cephalis semispherical, thorax pyramidal.

The basal spines extend from the central rod (under the neck stricture) to the thorax and continue in the thoracic wall to the very margin below where they protrude as "basal feet". The apical spine, D, runs chiefly in the wall of the cephalis (as in the two preceding species) [Helotholus histricosa, Dictyophimus clevei] and above is prolongated to a tophorn, which is only very little different to the byspines in appearance. This is also the case with the ventral, sagittal spine, which runs obliquely upwards and out through the neck stricture. All the main spines are narrow, not three-edged. Cephalis and thorax rather plentifully provided with narrow, needle-shaped byspines, which are longest and most numerous on the cephalis. The longest are as long, or even a little longer, than the diameter of the cephalis. The pores are uneven in shape and size, varying from quite small to $9 \mu$, not much smaller on the cephalis than on the thorax. Here too the three swellings on the upper part of the thorax between the main spines (fig. $89 \mathrm{~b}$ ) are to be found. The width of the lattice shell is $85 \mu$, its height (not including the basal feet) $68 \mu$. The cephalis alone is $34 \mu$ wide and $22 \mu$ high.

Very rare and only singly: 19/1 1899, 40miles NW of Gaukværø, 0-700 m.; Henningsvær, 21/2 1899, 0-250 m. Distribution: Probably boreal oceanic.

Lectotype. PMO224.479; Plate 5, fig. 12; Slide \#68 (M36/4).

Remarks. This species was found only twice in Jørgensen's radiolarian slides (\#64 and \#68). Unfortunately, the specimens are not complete, i.e. the basal feet are broken. However, we were able to identify the species based on its basal feet, circular in cross-section, and many needle-shaped byspines on the cephalis. The terminal feet on this species do not pierce through the thoracic wall, 
but are incorporated in the wall and protrude as three round needle-shaped spines at the terminal rim of the thoracic wall. Compare the Remarks for Dictyophimus clevei. Dictyophimus histricosus Jørgensen is regarded as the correct formal name.

$$
\begin{gathered}
\text { Euscenium corynephorum Jørgensen, } 1900 \\
\text { (P1. 5, fig. 14a-c) }
\end{gathered}
$$

1900 Euscenium corynephorum Jørgensen: 77-78 (not figured). 1905 Euscenium corynephorum Jørgensen; Jørgensen: 133-134; pl. 15 , fig. 70 .

\section{Original description (Jørgensen, 1900)}

Die drei Basalstacheln dreischneidig, allmählich gegen das distale Ende keulenförmig verdickt, spitz, in dem distalen Drittel, wo sie am breitesten sind, ungefähr dreimal so breit wie an dem entgegengesetzten Ende. Sie tragen 4 bis 5 dreigliedrige Wirtel ausgesperrter, dreischneidiger Stacheln (zweiter Ordnung), von welchen die innersten längsten mit einander und mit den Hauptstacheln durch dünne, ziemlich gerade, Brückenbalken verbunden sind. Das Apicalhorn (durch innere Columella mit den Basalstacheln vereinigt) ähnlich wie die Basalstacheln, nur kleiner und weniger stark keulenförmig verdickt. Zwischen Apical- und Basalstacheln eine kurz tetraëdrisch-glockenförmige Gitterschaale mit sehr ungleichen und unregelmässigen polygonalen Maschen und meistens ziemlich geraden, fast gleichbreiten (nicht eckig verdickten) Wänden, ungefähr wie bei Euscenium tricolpium. Gitterschaale ungefähr 0,085 bis $0,100 \mathrm{~mm}$. breit und hoch. Basalstacheln 0,150 bis $0,170 \mathrm{~min}$. hervorragend. Im jugendlichen Zustande gleicht diese Art einer Periplecta, indem man dann nur die zwei Paare der Hauptstacheln, durch einen kurzen Mittelstamm verbunden, findet. Die Art ist übrigens durch die nach aussen zu verdickten Hauptstacheln mit ihren zahlreichen ausgesperrten Aesten leicht kenntlich.

Selten: April-Mai, Juli-Decbr.

\section{Original description (Jørgensen, 1905)}

Has the four primary spines, about equally developed, and the ventral, sagittal one. The main spines are broad, three-edged, broadest in the outer half. On each edge there are from 3 to 5 , or more, strong slender pointed branches (spines), more or less distinctly scattered in comparison to those on the other edges of the same spine, only rarely here and there in distinct verticils. Between the neighbouring branches or the different main spines, rather long and fine connecting beams extend, these being in their turn again connected by numerous similar ones. Thus a more or less perfect net is formed which is best developed between the apical spine (D) and the ventral, sagittal one. This network forms a rather imperfect lattice shell with meshes, very uneven in shape and size, from small, triangular and trapezoidal to very large, polygonal openings. Also the inner branches (spines) on the same main spine are connected, partly with the main spine itself, partly with each other, also by fine connecting beams, parallel to the direction of the main spine (as in the spines of Rhizoplegma boreale). The meshes of the lattice shell strongly recall those of Cladoscenium tricolpium. Very often (in young individuals) so little of the network is developed that it would not be justifiable to consider the species as a Euscenium, if one did not occasionally find a well developed latice shell. Cfr. Jørgensen 1900. This species is very different from Cladoscenium tricolpium, and without doubt is more closely allied to those forms which have an imperfect lattice shell (Plectoidea HCK.). It might be classed as belonging to the genus Periplecta HCK., if it were not for the distinct, ventral, sagittal spine. (This spine was previously overlooked, and for this reason is not mentioned in my earlier description of the species [Jørgensen 1900] p. 77). I prefer at present to let it remain in the genus Euscenium, rather than to start a new genus, as the genus Euscenium HCK. certainly requires revision.

Lectotype. Plate 5, fig. 14a, b. Slide \#11 (N37/1), PMO224.480. Plate 5, fig. 14c, original drawing by Jørgensen (1905, pl. 15, fig. 70).

Remarks. This species is rather rare, but has been observed in several samples from the Norwegian Sea surface sediments.
Petrushevskaya (1971) is of the opinion that E. corynephorum should be assigned to the genus Clathromitra. We follow Jørgensen's taxonomy and Euscenium corynephorum Jørgensen is therefore regarded as the correct formal name.

\section{Gonosphaera primordialis Jørgensen, 1905}

$$
\text { (P1. 6, figs 1-2) }
$$

1905 Gonosphaera primordialis Jørgensen 133; pl. 14, figs 64-68. 2001 Gonosphaera primordialis Jørgensen, 1905; Dumitrica: 196; pl. 1 , figs $1-4$, pl. 2 , fig. 1 .

\section{Original description (Jørgensen, 1905)}

Gonosphaera (n. gen.): The very peculiar, little species which belongs here, seems to be constructed in the following way: There are two rather regular pentagons, having one side in common. Their planes form an angle of about $120^{\circ}$. At the four corners there are long spines, pointing obliquely outwards in different directions. Between the fifth corners, one in each pentagon, opposite to their common side, there is a three-jointed connecting arch, bent outwards from both the pentagons. This arch carries in the two corners which do not lie in the original pentagons (but farthest away from them), two long, diverging spines.

Gonosphaera primordialis (n. sp.): I will add a few remarks to the description already given of the genus. In most positions, this species will have the appearance of a more or less distinct pentagon, with long spines at the corners, and also a connecting arch with three similar spines. Looking straight towards one of the two pentagons (with a side in common), the connecting arch with its spines, will look like two long spines, connected by a short cross beam.

I cannot say where this species really belongs, but judging from the skeleton and the position of the central capsule, it would seem to belong to the Nassellaria. I have, however, only once seen the plasmatic parts. The species does not seem to be so very rare, but is easily overlooked on account of its small size.

Found in rather many samples from deep water, always in small numbers.

Distribution: Also on the west coast of Norway. Probably boreal oceanic.

Lectotype. PMO224.481; Plate 6, fig. 1; Slide \#35 (H32/0).

Remarks. Dumitrica (2001, p. 192) discussed and made a new description of this species and concluded: (1) 'The genus, represented by only its type species - Gonosphaera primordialis Jørgensen, was questionably assigned to Nassellaria ...'; (2) 'Described as such, the skeleton of Gonosphaera cannot any longer be considered as belonging to Nassellaria. Having as initial skeleton a spicule with a median bar and three diverging spines at either end, it is a member of the order Entactinaria Kozur \& Möstler, 1982 and of the family Excentroconchidae HOLLANDE \& ENJUMET, 1960.' In accordance with the new description and taxonomic placement, Gonosphaera primordialis Jørgensen is regarded as the correct formal name.

Helotholus histricosa Jørgensen, 1905

$$
\text { (P1. 6, figs 3-6) }
$$

1905 Helotholus histricosa Jørgensen: 137; pl. 16, figs 86-88.

\section{Original description (Jørgensen, 1905)}

The ventral sagittal spine about equal in strength to the others and is directed a little upwards. The primary, lateral spines are nearly horizontal, bent slightly downwards; they protrude at the neck stricture, rather far up. The dorsal spine, A, is directed downwards and pierces the thorax rather far down. Only the dorsal spine, A, runs for a short distance in the very wall of 
the thorax, the others pierce only the wall. The cephalis is semispherical, or a little higher, in cross section circular. The thorax is broadly campanulate. The pores are irregular in shape and size, most of them being roundish or oblong, smallest on the cephalis $(1-16 \mu)$, largest on the thorax, especially down below on young individuals. Here the brim of the thorax is furnished with numerous, irregularly placed, short spines, which are not true byspines, but only the walls of meshes which are not yet developed. On the cephalis and thorax, narrow needle shaped byspines are scattered, the longest being about equal in length to the diameter of the cephalis. I have not seen any individuals which could be supposed to be fully developed. The species does not answer well to any of Haeckel's genera. From the genus Lithomelissa, as I have understood it in the species $L$. setosa, there are such important differences that it does not seem reasonable to place these two forms in the same genus. It might rather be united with the following species [Dictyophimus clevei, D. histricosus]. I have not, however, done so, more especially as the definition of Haeckel's genus Dictyophimus requires that there should be three thoracic ribs which are lengthened out to 'basal feet', and this definition may at a pinch be made to apply to the two following species, but not at all to Helotholus histricosa. Rather rare, sparse, in deep water samples. Distribution: Seems also to be a boreal, oceanic species.

Lectotype. PMO224.482/1; Plate 6, fig. 3; Slide \#40 (M40/0 bottom).

Paralectotype 1. PMO224.483; Plate 6, fig. 4; Slide \#62 (N43/1).

Paralectotype 2. PMO224.482/2; Plate 6, fig. 5; Slide \#40 (M40/0 top).

Remarks. All specimens on slide \#40 were identified by Jørgensen as Helotholus histricosa. This species differs from Sethoconus galea (Cleve, 1899, p. 33, pl. 4, fig. 3) as the latter species is larger with a more robust skeleton, thorax not as campanulate as $H$. histricosa, and the apical horn is more prominent and robust. Petrushevskaya (1971) transferred both species to the genus Ceratocyrtis and also made $S$. galea a synonym of $C$. histricosa. We agree with the change of genus but do not agree with synonymizing these two species. Ceratocyrtis histricosa (Jørgensen, 1905 ) is regarded as the correct formal name.

\section{Lithomelissa hystrix Jørgensen, 1900}

$$
\text { (P1. 6, figs 7-9) }
$$

1900 Lithomelissa hystrix Jørgensen: 83 (not figured).

1905 Lithomelissa hystrix Jørgensen; Jørgensen: 136; pl. 16, fig. 85.

\section{Original description (Jørgensen, 1905)}

Lithomelissa (n. gen.): The four primary spines, A, D, Lr and Ll, are present, as well as the ventral, sagittal one. The apical spine, D, runs in the wall of the cephalis, and protrudes like a needle-shaped tophorn, the lower part being inside the lattice shell. The dorsal, basal spine, A, protrudes obliquely like a simple spike (needle), rather far down on the thorax. On the inside, it is propped up against the shell by arch-shaped supporting beams (corresponding to the apical arches in Phormacantha hystrix). The lateral spines pierce the thorax in its upper part and protrude each of them as (one or?) two spikes. The ventral, sagittal spine protrudes near the region of the neck (between cephalis and thorax), and is, in Lithomelissa setosa, connected to the right lateral spine, L1, by an inner little lattice-plate, whilst it is farther distant from the left, lateral spine. In other words, it divides the angle between the lateral spines into two very uneven parts, one small one to the right, and a larger one to the left. By this feature, young forms of Lithomelissa setosa are easily recognized, even if only the cephalis be developed. The primary arches between $\mathrm{D}, \mathrm{Lr}$ and $\mathrm{Ll}$ are well developed, and protrude on the inside like three archshaped ledges, running upwards. By means of outwards and downwards bent byspines from these primary arches, together with branches and arches from the dorsal spine, $\mathrm{A}$, and the lateral ones, the thorax is developed. In the upper part of the thorax, there are, therefore, formed three, more or less distinct swellings, a right one, below the primary, right, lateral arch, a left one, below the left, lateral arch, and a ventral one, below the primary, ventral arch. Here too, as in all the forms of Cyrtoidea occurring in my material, there is an inner axial spine, pointing downwards vertically from the ventral end of the central rod, thus having the same starting point as the ventral, sagittal spine.

Lithomelissa hystrix (n. sp.): Cephalis not very high, finally, by the development of secondary, outer arches in the region of the neck, a broad semisphere, which is half of it sunk into the thorax. The thorax is above campanulate, below cylindrical, with two distinct, lateral indentations in the upper part. In the region of the neck in younger individuals, there are large holes, which later on are, to some extent, closed, by the development of outer arches between the lower part of the cephalis and the upper part of the thorax. The pores outside this region of the neck are roundish, of very varying size, being smallest on the upper part of the cephalis. On the whole, there appears to be the same spines as in L. setosa, but fewer really protruding ones from the inner skeleton. The thorax here too appears to be similarly formed to that of $L$. setosa, from strong, obliquely downwards pointing byspines on the primary arches. A number of such obliquely protruding byspines are also seen in this species in the region of the neck. In addition, there are also numerous, needle-shaped byspines on the cephalis and the upper part of the thorax, and these, on a broad part of the shell, between the cephalis and thorax, develop fine, connecting beams, covering the large neck openings. The region of the neck will here, in this way, be surrounded by a covering which causes the cephalis finally to be half (or wholly?) sunk into the thorax. This outer covering is chiefly formed from byspines on secondary arches. Cephalis $22 \mu$ broad, thorax $45-50 \mu$ broad. The height of the thorax in the forms occurring in my material $34-40 \mu$. In these forms, which most probably were not fully developed, the brim of the thorax was provided beneath with short irregular spines, which no doubt are the walls of meshes in process of development. It is a question whether this species should not be more correctly separated from the genus Lithomelissa. But as I have not as yet had an opportunity of studying the inner skeleton more carefully, I will, for the present, retain it in the genus in which I originally placed it. Very rare and occurs only sparsely: 19/11899, 40 miles NW of Gaukværø, 0-700m; 28/3-1899, the Tys Fiord I, 0-700 m. Distribution: Also very rare on the west coast of Norway.

Lectotype. PMO224.484/1; Plate 6, fig. 7a; Slide \#30 (M34/0 bottom). Plate 6, fig. 7b original drawing by Jørgensen (1905, pl. 16, fig. 85).

Paralectotype 1. PMO224.484/2; Plate 6, fig. 8; Slide \#30 (M34/0 middle).

Paralectotype 2. PMO224.484/3; Plate 6, fig. 9a, b; Slide \#30 (M34/2).

Remarks. Slide \#30 includes only three radiolarian specimens. As marked on the slide label, Jørgensen identified all three as Lithomelissa hystrix. This species is smaller than L. setosa, cephalis spiny, submerged into thorax wall. Lithomelissa hystrix Jørgensen is regarded as the correct formal name.

\section{Lithomelissa laticeps Jørgensen, 1905} (Not illustrated)

1905 Lithomelissa laticeps Jørgensen: 136; pl. 16, figs 84a-b.

\section{Original description (Jørgensen, 1905)}

As yet, I am only imperfectly acquainted with this species which seems related to $L$. thoracites HCK. and $L$. mediterranea J. MÜLL. It differs from the preceding one $[L$. setosa] in having a larger cephalis, which is broader and more obtuse, and by the want of byspines. Neither does there 
appear to be any other protruding spines than the principal ones, with perhaps a couple of branches.

The thorax has no marginal byspines beneath. The pores here on the lower margin are larger and the walls thinner, so that probably the individual illustrated is not yet fully developed.

Vary rare and only singly: Sea off Røst, 22/3 1899, 0-900m.

Distribution: I have seen it in a deep water sample from the sea between the Færø and Shetland Isles (cfr. Above, p. 128).

Types. Not defined.

Remarks. This species has not been observed in Jørgensen's radiolarian slide collection. However, we have recovered multiple $(>50)$ specimens identical to Jørgensen's drawing of this species (1905, pl. 16, fig. 84a) in the plankton in the Sogndalsfjord on 10 March 2010 (see www.radiolaria.org for images). This species is also present in surface sediments in the Norwegian Sea. Lithomelissa laticeps Jørgensen is regarded as the correct formal name.

Lithomelissa setosa Jørgensen, 1900

(P1. 6, figs 10-17)

non Botryopyle setosa Cleve, 1899: 27; pl. 1, fig. 10a, b. 1900 Lithomelissa setosa Jørgensen: 81-82; pl. 4, fig. 21. 1905 Lithomelissa setosa Jørgensen; Jørgensen: 135-136; pl. 16, figs $81-83$, pl. 18, fig. 108.

\section{Original description (Jørgensen, 1900)}

Cephalis gerundet, meist mit undeutlicher Halsstrictur und 3 bis 6 aufrecht divergirenden, schmalen, cylindrischen Stacheln, die 1- bis 2-mal so lang wie der Cephalis sind. (Nur 2 von diesen scheinen direkt vom inneren Skelett auszulaufen). Poren sehr dickwandig, klein, rundlich, ungleich gross, gegen den Thorax zu häufig grösser. Thorax glockenförmig, meist etwas länger als breit, häufig - wie auch der Cephalis - etwas buckelig, daher im Umriss etwas unregelmässig.

Poren sehr ungleich gross, unregelmässig, rundlich, länglich und eckig, breitwandig (an erwachsenen Exemplaren). Häufig werden die Poren nach unten (gegen den Saum des Thorax) allmählich grösser. Die drei Basalstacheln sammt deren Aesten und den secundären Mittelstacheln durchbrechen den Thorax in verschiedener Höhe, von der Halsregion ab bis dicht vor dem unteren Saum. Mit der Höhe wechselt auch die Richtung der Stacheln. In der Halsregion laufen sie horizontal aus, während sie unweit des Thoraxsaumes stark nach unten gerichtet sind. Am Thoraxsaume finden sich mehrere (gewöhnlich ungefähr sechs) nach unten gerichtete, mehr oder weniger lange, nadeiförmige Stacheln, die meistens unregelmässig schief verlaufen. Sämmtliche Stacheln sind cylindrisch, die längeren ungefähr um die Breite der Schaale hervorragend. Die grösseren auslaufenden Stacheln sind an der Aussenseite der Gitterschaale durch einen kleinen Gitterfuss (mit sehr wenigen Maschen) gegen dieselbe aufgestützt. Durchmesser des Cephalis ungefähr 0,032 mm., gewöhnlich etwas weniger hoch. Länge des Thorax 0,068 bis $0,075 \mathrm{~mm}$., Breite 0,050 bis 0,070. Häufig, immer aber mit geringer Individuenanzahl vorkommend: Febr.-Decbr. Diese Art scheint sehr variabel zu sein. Ich versuchte anfänglich die zahlreichen Formen aus einander zu halten, gelangte aber später zu der Auffassung, dass die grosse Mannigfaltigkeit der Formen sich hauptsächlich als Verschiedenheiten der successiven Altersstufen erklären liessen. Ausserdem scheint - wie erwähnt - diese Art sehr variabel zu sein. An jüngeren Individuen bemerkt man nur wenige 'Apicalhörner', dünnere Zwischenwände der Maschen (mehr polygonalen Poren) sammt kürzerem Thorax, dem auch der untere bestachelte Saum fehlt. Man sieht dann auch meistens die Poren allmählich gegen den unteren Theil des Thorax sehr viel grösser werden, während die Wände hier sehr zart sind.
Solche Formen weichen von der Gestalt der erwachsenen Individuen so sehr ab, dass man sie unbedingt als andere Arten ansehen würde, falls man nicht die sehr zahlreichen Uebergangsformen fände.

\section{Original description (Jørgensen, 1905)}

Compare above the description of the genus and of the structure of the species in the introduction to the group Nassellaria. Cfr. to Jørgensen (1900) where a detailed description will be found. Of byspines, there are usually two strongly developed one on the right, lateral arch, protruding in the form of simple spikes in the upper part of the thorax, one or two similar ones on the left, lateral arch, and a couple on the cephalis. The spikes, which are seen in varying numbers and differently developed on the lower margin of the thorax are - at any rate most often - only temporary formations. They disappear later on as the development of the thorax progresses, the meshes being formed between these spines. It is possible that var. belonophora Jørgensen (1900, pl. 4, fig. 22) is the fully developed form, and that its marginal spines are therefore permanent. Frequent, mostly in deep water samples, sometimes - but rarely - in the surface. Rarely at all numerous. Distribution: Belongs to the most frequent Radiolaria on the west coast of Norway.

Lectotype. PMO224.485/1; Plate 6, fig. 10a, b; Slide \#34 (O39/4 lower right). Plate 6 , fig. 10c original drawing by Jørgensen (1905, pl. 18, fig. 108a).

Paralectotype 1. PMO224.485/2; Plate 6, fig. 11; Slide \#34 (O39/4 top).

Paralectotype 2. PMO224.485/3; Plate 6, fig. 12; Slide \#34 (O40/3 top).

Paralectotype 3. PMO224.485/4; Plate 6, fig. 13; Slide \#34 (O40/3 bottom).

Remarks. When Lithomelissa setosa was described by Jørgensen (1900), it was not described as a new species but as a possible synonym for Botryopyle setosa Cleve, 1899. This is certainly a mistake, as also noted by Jørgensen (1905), as the form described by Jørgensen (1900) looks nothing like the trilobated-cephalisform shown in the drawing of Cleve (1899, pl. 1, fig. 10a, b). The latter clearly depicts the species presently called Amphimelissa (Botryopyle) setosa. Jørgensen's description in 1900 should therefore be regarded as the type description of Lithomelissa setosa. This species is very common in west Norwegian fjords, and is also common in the warm Atlantic water off the west coast of Norway. Normally it is found with an open thorax, leading Jørgensen to suggest that it is a juvenile stage of Lithomelissa setosa var. belonophora; see Remarks below to this variety. Lithomelissa setosa Jørgensen is regarded as the correct formal name.

\section{Lithomelissa setosa var. belonophora Jørgensen, 1900}

$$
\text { (P1. 6, figs 14-17) }
$$

1900 Lithomelissa setosa var. belonophora Jørgensen: 82-83; pl. 4, fig. 22 .

\section{Original description (Jørgensen, 1900)}

Cephalis hoch halbkugelförmig, 0,020 bis $0,027 \mathrm{~mm}$. hoch, 0,031 bis $0,027 \mathrm{~mm}$. breit, gegen den Thorax nicht oder kaum eingeschnürt, mit rundlichen, kleinen, sehr dickwandigen Poren und 6 cylindrischen, schmalen Hörnern, die wie bei den zwei vorhergehenden Arten verlaufen. Länge der Hörner ungefähr so gross wie der Durchmesser des Cephalis. Thorax glockenförmig, in der unteren Hälfte fast cylindrisch, $0,069 \mathrm{~mm}$. lang, bis 0,053 breit, nach der Längsaxe unsymmetrisch (an der einen 
Seite oben etwas buckelig), mit sehr ungleich grossen, meist ziemlich kleinen, sehr dickwandigen Poren. Die drei Basalstacheln ziemlich kurz auslaufend, in verschiedener Höhe die Thoraxwand durchbrechend, hier mit einem sehr kleinen Gitterfuss versehen. Am unteren Thoraxsaum ungefähr 8 bis 9 kräftige, nadelförmige, hinabgerichtete Stacheln. Der Saum ist gewöhnlich etwas verengt; sehr selten ist hier ein kurzer, enger Cylinder (wie ein kurzes Ansatzrohr) ausgebildet. Selten in Tiefseeproben: Febr., April - Mai, Juli - Novbr.

Lectotype. PMO224.497/1; Plate 6, fig. 14; Slide \#73 (N37/0).

Paralectotype 1. PMO224.497/2; Plate 6, fig. 15; Slide \#73 (M36/4).

Paralectotype 2. PMO224.497/3; Plate 6, fig. 16; Slide \#73 (M37/3).

Remarks. Lithomelissa setosa is normally found with a rather short thorax. It might therefore be, as suggested by Jørgensen (1905), that Lithomelissa setosa var. belonophora is its fully adult form, as indicated by permanent marginal spines, and with a closed or semiclosed basal thorax (Pl. 6, figs 14-15). The latter specimens also show a peristome-like structure with terminal spines. The significance of var. belonophora is uncertain. We have not seen any clear differences in the distribution pattern of the two forms. In our earlier studies we have not discriminated between the two and have regarded them as one and the same species. Lithomelissa setosa Jørgensen is regarded as the formal name of this variety.

\section{Peridium longispinum Jørgensen, 1900}

$$
\text { (Pl. 6, figs 18-19) }
$$

1900 Peridium longispinum Jørgensen: 75-76 (not figured).

1905 Peridium longispinum Jørgensen; Jørgensen: 135; pl. 15, figs $75 a, b, 76 a-d, 77-79$, pl. 16, fig. 80.

\section{Original description (Jørgensen, 1900)}

Gitterschaale fast kugelig, etwas beutelförmig (die grösste Breite unter der Mitte), mit rundlichen, ungleich grossen, breitwandigen Poren (die grössten unweit der Hauptstacheln), 0,002 - 0,005 - 0,008 mm. breit (Zwischenwände 0,0015 bis $0,002 \mathrm{~mm}$.). Die ganze Schaale ist mit zahlreichen feinen, nadelförmigen Nebenstacheln versehen, die länger als der Radius sind. Hauptstacheln lang, bis 0,104 mm. über die Schaale herauslaufend, nadelförmig. Länge der Schaale vom gemeinsamen Anfangspunkt der Radialstacheln gerechnet $0,045 \mathrm{~mm}$., grösste Breite 0,044 .

Die äusseren (hier oberen) Aeste der Vorder- und Hinterstacheln (zum oben erwähnten dreigliedrigen Astwirtel gehörig, vergleiche oben unter Periplecta intricata) sind in kurze Dorne umgewandelt; der entsprechende Ast des Mittelstachels dagegen lang, auslaufend. Wie an Periplecta intricata findet man auch hier einen kräftigen Hinterbogen zwischen dem Mittel- und dem Hinterstachel, einen ähnlichen Vorderbogen sammt einem Hauptbogen, der mit dem Vorderbogen einen kurzen gemeinsamen, vom Vorclerstachel nach unten entspringenden Stamm, besitzt. Auch hier ist kein direkter Zusammenhang zwischen dem Hinter- und dem Hauptbogen vorhanden; jeder derselben entspricht einem Ast der erwähnten dreigliedrigen Wirtel. Von oben her gesehen zeigen sich also drei grosse Maschen, nach aussen von den drei primären Bögen begrenzt. Dann folgt die Gitterschaale, die unter dem auslaufenden Theil der Basalstacheln grössere Poren aufweist. Der Hinterbogen ist mit zwei kräftigen, durch einen Brückenbalken gegenseitig verbundenen, nach aussen und oben gekrümmten, ansehnlichen Stacheln bewaffnet. Der Vorderbogen trägt einen oder zwei ähnliche Stacheln (bis $0,030 \mathrm{~mm}$. lang). Nebenstacheln der Gitterschaale bis $0,030 \mathrm{~mm}$. lang, der unterste (etwas schief gerichtet) am grössten, fast so lang wie der Durchmesser. Selten: April—Mai, August—Oktbr.

\section{Original description (Jørgensen, 1905)}

I am for the present not quite sure whether or not there are at least two different species included under this name. What makes it still more difficult is that young forms of Dicyrtida often have the appearance of a Peridium, so that it is necessary to be very careful in the determination. On older, well developed forms there is a cephalis which is broadest above the middle, then quickly rounded off upwards and conically narrowed downwards. The lattice shell is well developed and closed all round. The pores vary considerably in size, from very small and round to large, oblong and polygonal. The main spines protrude far out. The very long and very narrow points seem only to occur in younger individuals. Large byspines, strongly bent outwards, are found on the right and left lateral arches. Besides, there are smaller, straight byspines scattered over all the surface of the shell, stronger and fewer in number at the basal opening, numerous and fine, narrow, needle-shaped on the upper side of the cephalis. Younger individuals (if these do belong to the same species) with larger, more irregular pores, thinner beams, less perfectly developed lattice shell and long and narrow main spines. The cephalis in such forms is generally rounder, and often broader than it is high. Here again we find the characteristic course of the primary arches as mentioned under Plectacantha oikiskos. The larger secondary meshes and spines, which are mentioned at the same place, are also present here. Rather rare, in deep water samples, up to $50 \mathrm{~m}$. Distribution: Also on the west coast of Norway, rare. Occurred too in two surface samples from the warmer, salter Atlantic waters, 2/2/1901, off Søndmøre, and 5/3/1901 off Lofoten.

Lectotype. PMO224.486; Plate 6, fig. 18; Slide \#67 (O40/0).

Remarks. Adult forms of this species have a well-rounded cephalis with rather well-developed circular main spines. Pores are irregularly rounded, different in size, and the two basal pores connecting the A spine with the $\mathrm{Ll}$ and $\mathrm{Lr}$ spines are usually large. Peridium longispinum Jørgensen is regarded as the correct formal name.

Phormacantha hystrix (Jørgensen, 1900)

$$
\text { (Pl. 6, figs 20-24) }
$$

1900 Peridium hystrix Jørgensen: 76-77 (not figured).

1905 Phormacantha hystrix (Jørgensen); Jørgensen: 132; pl. 14, figs $59 \mathrm{a}-\mathrm{d}, 60-63$.

\section{Original description (Jørgensen, 1900)}

Bei dieser Art ist der Apicalstachel (einer der Basalfüsse nach HCK., vergleiche oben) am längsten, $0,146 \mathrm{~mm}$. lang, der Mittelstachel am kürzesten, $0,083 \mathrm{~mm}$. Vorder- und Hinterstachel ungefähr $0,114 \mathrm{~mm}$. Alle Stacheln sehr fein auslaufend. Die Gitterschaale länglich, sehr zart, durch schmale, nicht deutlich eckig verdickte Balken gebildet, die unregelmässige, ungleich grosse, z. Th. sehr weite, polygonale Maschen umschliessen. Zahlreiche, sehr feine, kurze Nebenstacheln (nicht nur in den Maschenecken), die mehr oder weniger vollständig durch sehr feine, dornige Bögen verbunden sind. Die ganze Gitterschaale in dieser Weise von einer unvollständigen arachnoidalen Hülle umsponnen. Auch bei dieser Art findet man die drei primären Bögen, die wie bei den vorhergehenden Arten laufen. Hier ist aber ein vierter basaler Stachel zwischen dem Vorder- und dem Hinterstachel ausgebildet. Diesen Stachel, den man auch im folgenden wiederfindet, nenne ich hier der Kürze halber den secundären Mittelstachel. Er ist immer schwächer als die primären entwickelt. Der lange Apicalstachel trägt weit unten einen dreigliedrigen Wirtel zarter Aestchen. Jedes dieser Aestchen ist durch zarte, dicht dornige, weite Bögen mit Aesten oder Bögen, die von den übrigen Hauptstacheln entspringen, verbunden. Da ich leider diesmal nicht im Stande bin, die nöthigen Figuren der Beschreibung begleiten zu lassen, glaube ich es nicht der Mühe werth, den ziemlich complicirten Verlauf dieser (übrigens wichtigen) Bögen zu schildern. Diese Art ist auch im jungen Zustand durch die erwähnten weiten, dicht dornigen, zarten Bögen kenntlich. Die Gitterschaale scheint 
erst spät unten geschlossen zu werden. Länge der Gitterschaale $0,058 \mathrm{~mm}$. Maschen 0,006-0,017 mm. weit. Nebenstacheln 0,010-0,020 mm. lang.

Nicht sehr-selten: Juni-Oktbr., Novbr. —Decbr.

\section{Original description (Jørgensen, 1905)}

The primary spines and primary arches as in Plectacantha oikiskos. The ventral arch and the left, lateral one also here run together to a strong, basal arch branch from the left, lateral main spine. Outside the ventral, sagittal spine, there is an extended network of numerous, secondary meshes, which both below and on the sides are connected by fine transverse beams to a corresponding one on the sides of the dorsal sagittal spine. In this way a network is formed, which is imperfectly closed beneath. There are numerous byspines. Between these and the larger beams more or less numerous and mostly thin, arch-shaped, connecting beams are extended, which are in their turn here and there connected by similar, arched, fine beams, which at a later stage of development are provided with numerous, fine spines. These are, possibly, later, at any rate to some extent, developed to similar fine connecting arches, which more or less completely envelope the network. The development of the arches is here further advanced than in Plectacantha oikiskos. From the three branches of the apical spine, arch branches extend, the apical arches, one to the dorsal, basal spine, and two to the primary, lateral arches. These apical arches may at the corners, as well towards the apical spine, as towards the dorsal one and the primary arches, be enveloped by similar arches. Cfr. also Jørgensen 1. c. p. 77. At a younger stage, this species strongly resembles Plectacantha oikiskos. The ventral, sagittal spine, however, makes it easy to distinguish between them. At an older stage, they are so different that they can hardly be confounded. It is likely that there is more than one species which belongs here. This form is very interesting, clearly being a connecting one between the groups Plectoidea and Monocyrtida. I formerly considered it to belong to the genus Peridium, and there is hardly any great or important difference in the structure of the genera Peridium and Phormacantha. It seems, however, most practicable to separate the imperfectly latticed forms from those which have a regularly developed lattice work which is closed beneath. On the other hand, this genus - as more fully explained in the introductory remarks to Nassellaria - forms clearly a transition to the genera Euscenium HCK. and Cladoscenium HCK. When the apical arches are further developed, an enclosed spine will result, a "columella". The larger forms have a 'network', which is about $70 \mu$ in height. Rather frequent, though never numerous, in deep water samples. Rather frequent, though never numerous, in deep water samples. Distribution: The same as that of Plectacantha oikiskos.

Lectotype. PMO224.487/1; Plate 6, fig. 20a, b; Slide \#33 (M38/4 upper right).

Paralectotype 1. PMO224.487/2; Plate 6, fig. 21a, b; Slide \#33 (M38/4 lower left).

Paralectotype 2. PMO224.488; Plate 6, fig. 22; Slide \#62 (L30/4).

Remarks. This species is characterized by its rounded and well-developed main spines, and its large arch-shaped openings connecting the Apical and the $\mathrm{Ll}$ and $\mathrm{Lr}$ spines. Above these arches is a second set of arches, giving the impression of a very open skeleton when observed from the apical-dorsal side. Generally, the skeleton is loosely constructed, with large irregularly rounded pores. In modern nassellarian taxonomy the three basal spines $(\mathrm{D}, \mathrm{Lr}, \mathrm{Ll})$ point downwards, away from the cephalis, while the apical (A) spine points into the cephalis and normally pierces the cephalic wall. Petrushevskaya
(1971, p. 14, fig. 7) has a detailed discussion of this and points out that Jørgensen has orientated his specimens differently from all other authors. Normally we orientate the cephalis upwards with the apical spine downwards, but in Jørgensen (1905) the apical spine is orientated upwards while the cephalis points downwards. This means that the A and D spines in the illustrations by Jørgensen (1905) must change places. Phormacantha hystrix (Jørgensen, 1900) is regarded as the correct formal name.

\section{Plectacantha oikiskos Jørgensen, 1905}

$$
\text { (P1. 7, figs 4-9) }
$$

1899 ?Peridium intricatum Cleve: 31; pl. 2, fig. 8a, b. 1900 Periplecta intricata Jørgensen: 73 (not figured). 1905 Plectacantha oikiskos Jørgensen: 131-132; pl. 13, figs 50-57.

\section{Original description (Jørgensen, 1905)}

The primary verticil of branches of the apical spine has (generally?) only two branches, pointing upwards and outwards in the angle between the dorsal, basal spine and the lateral ones. These two branches together with the protruding middle stem form three undivided spikes, about equal in length. The left, lateral spine, $\mathrm{Ll}$, has the primary verticil complete. Of these three branches, however, the inside one is - as previously mentioned - transformed onto a short, strong arch, pointing downwards, at the end of which the left, lateral arch and the primary, ventral one meet. The two other branches form with the protruding middle stem, three, diverging, long, single spikes, pointing obliquely outwards and to the sides. By these three long, protruding spikes, the left, lateral spine may always be easily recognized. The right, lateral spine has only retained one branch of the verticil in its original form, the other two being branches for the two corresponding, primary arches, one belonging to the ventral arch, the other to the right, lateral one. There are consequently here two long, simple spikes, about equal in length, the outer branch in the primary verticil and the protruding, middle stem. The dorsal, basal spine has only one simple branch of the verticil, pointing outwards and upwards, the two others being strong, arched branches, diverging nearly at right angle on both sides. One of these branches forms the right, the other the left lateral arch. The middle stem of the basal spine is here branched, there being one or two similar secondary arches outside the primary, lateral ones. The dorsal, basal spine, therefore, only shows one simple, protruding spike. A similar, smaller byspine is generally to be found farther out. The dorsal spine is the longest and strongest, the apical one the shortest and weakest. Outside the primary meshes, secondary ones are developed more or less richly, varying considerably in size. These unite to form a 'network' which is generally rather imperfect, but would seem, on older individuals, to be made more complete by the addition of connecting beams across the larger, secondary meshes, so that these meshes finally are smaller in size and more in number. Generally speaking, the network is conically expanded downwards, and seems, in the case of older individuals, finally to be imperfectly closed beneath by the development of a few, fine, long, transverse beams. In the material examined specimens with such nearly closed network were always rare. Of the more important byspines and secondary meshes, I will only mention the following which seem always to be present, and may serve to help in identifying the species. Under the protruding right lateral spine a large, secondary, pentagonal mesh will be found. The left, lateral arch has a strong byspine in the middle, pointing outwards and upwards, and under it, there is a large, secondary mesh. On both sides of the dorsal spine, outside the primary, lateral arches, on the left side will be found two secondary meshes, and on the right side one; the latter being the largest but it is perhaps later on divided into two. Moreover, on all the stronger arches, there is a more or less rich development of byspines, pointing outwards and upwards, sometimes twins, directed upwards-outwards and downwards-outwards. The beams are thin 
in young individuals, especially at the outer secondary meshes; they are much stronger on older individuals. The length of the basal, dorsal spine is $+/-55 \mu$. Cfr. Jörgensen 1900. I considered this species first to belong to the genus Periplecta HCK.; but as I later on found that what with HAECKEL characterizes this genus is also characteristic of all closely related genera, as I am acquainted with them from plankton samples (not drawings), I have been obliged to change the name of the genus. I at first considered this species to be CLEVE's Peridium intricatum, and this may be correct, but it cannot be proved to be so from CLEVE's illustration nor from his description. As it is, moreover, quite as probable that CLEVE's Peridium (?) laxum also belongs to this species, I consider it best to retain the manuscript name I originally had given the species before CLEVE's work was published. Nor rare, but always in small numbers. Distribution: Not rare on the west coast of Norway, always scarce. Probably boreal oceanic.

Lectotype. PMO224.489; Plate 7, fig. 4; Slide \#35 (S42/2).

Paralectotype 1. PMO224.490; Plate 7, fig. 5a, b; Slide \#10 (N41/3).

Paralectotype 2. PMO224.491; Plate 7, fig. 6; Slide \#64 (D35/4).

Remarks. Jørgensen's radiolarian slide \#10 has one individual and Jørgensen identified this as Periplecta oikiskos (marked on slide label), a genus name that he never used again. That he used this genus on the slide could be related to the fact that he had earlier (1900) identified this species as Periplecta intricata (Cleve, 1899). However, in 1905 he placed it into his newly erected genus Plectacantha. We regard Plectacantha oikiskos Jørgensen as the correct formal name.

Plectacantha trichoides Jørgensen, 1905 (P1. 7, figs 1-3)

1905 Plectacantha trichoides Jørgensen: 132; pl. 13, fig. 58.

\section{Original description (Jørgensen, 1905)}

I have only an imperfect knowledge of this species, as I have only seen a few specimens, and at first took these to belong to the preceding species [Plectacantha oikiskos]. It has the same primary spines and primary arches; but there appears to be the important difference that the ventral, primary arch and the left, lateral arch both extend to the left, lateral spine, not to a common basal branch from the latter. On the other hand, there is a strong, secondary arch between the left, lateral one and the nearest side of the primary, ventral one. In outer appearance, this species is very different from the foregoing one. Instead of the numerous secondary meshes, long connecting arches are developed, which form together a longish, ovate, very imperfect network of long, fine arches. The largest and strongest of these run between the two lateral arches and form a very large, ovate mesh, pointing downwards. On its sides, especially in a ventral direction, similar large meshes are developed, bounded by fine arch branches, which run from the primary arches to the said large, secondary one, or between secondary arches. On these arch branches, very fine spines are scattered, these probably later on being, developed into arch branches between the secondary arches. It is likely that a network will appear which is imperfectly closed beneath by basal, secondary arches, on elder individuals. On the primary, basal spines, short byspines are also found on the pieces inside the primary arches. This species is undoubtedly different from the foregoing. It is not certain whether it should be reckoned as belonging to the same genus; but it wants, as does the foregoing one, the ventral, sagittal spine. Very rare and scarce, though certainly to some extent overlooked: 19/1 1899, 40 miles NW of Gaukværø, 0-700 m. Distribution: Also on the west coast of Norway, but only occasionally and in small numbers.

Lectotype. PMO224.492; Plate 7, fig. 1a, b; Slide \#35 (W36/1).
Paralectotype. PMO224.493; Plate 7, fig. 2a, b; Slide \#42 (N40/0).

Remarks. Plectacantha trichoides and P. oikiskos are quite similar and difficult to separate at the juvenile stage. However, adult forms of $P$. trichoides are recognized easily by the large primary arches that replace the numerous small secondary meshes observed in P. oikiskos. Plectacantha trichoides Jørgensen is regarded as the correct formal name.

\section{Pterocorys amblycephalis Jørgensen, 1900}

(Not illustrated - see Remarks)

1900 Pterocorys amblycephalis Jørgensen: 87 (not figured). 1905 Androcyclas gamphonycha Jørgensen: 139; pl. 17, figs 92-97.

\section{Original description (Jørgensen, 1900)}

Cephalis cylindrisch, oben flach abgestutzt und fast scharfkantig, bisweilen hier etwas breiter als unten (also umgekehrt kegelförmig) mit einem kräftigen dreischneidigen Horn, ungefähr von derselben Länge, versehen. Poren klein, dickwandig, rundlich und oval, ungefähr 4 auf dem Durchmesser (etwas grösser an der Basis des Hornes). An dem Uebergang zum Thorax ein querbreiter Halstheil wie bei den vorhergehenden Arten [P. gamphonyxos], nur wenig breiter als der untere Theil der Cephalis. Thorax breit kegelförmig mit ungleich grossen, rundlichen und polygonalen, nach unten grösseren Poren, die grössten bis dreimal so gross wie diejenigen des Cephalis. Abdomen unvollständig, von einer einzigen Reihe grosser, rundlicher, dünnwandiger Poren gebildet. Der Mündungssaum uneben, von den unteren Wänden dieser grossen Poren gebildet, daher grob und unregelmässig crenuliert. (Wahrscheinlich ein junges Individuum). Wie bei den zwei vorhergehenden Arten finden sich auch hier dünne Skelettbalken, die in feine kurze Stacheln in dem oberen Theile des Thorax und in der Halsregion auslaufen. Selten: April - Mai, Oktbr. - Novbr.

Types. Not defined. See Remarks.

Remarks. In 1905 (p. 139), Jørgensen synonymized Pterocorys amblycephalis with Androcyclas gamphonycha in the text. However, in his 1905 pl. 17, figs 95-97 he still uses the name Pterocorys amblycephalis. As P. amblycephalis is regarded as a juvenile of $A$. gamphonycha we are depicting these together in our Plate 4. The juvenile form (previously defined as $P$. amblycephalis) is in Plate 4, figs 4-5. Androcyclas gamphonycha Jørgensen is regarded as the correct formal name.

$$
\text { Pterocorys gamphonyxos Jørgensen, } 1900
$$

(Not illustrated - see Remarks)

1900 Pterocorys gamphonyxos Jørgensen: 86 (not figured). 1905 Androcyclas gamphonycha Jørgensen: 139; pl. 17, figs 92-97.

\section{Original description (Jørgensen, 1900)}

Cephalis wie an der vorhergehenden Art und Theocalyptra amblycephalis kurz und cylindrish, unten mit einem wenig erweiterten querrectangulären Halstheile. Poren dickwandig, ungleich gross, klein, rundlich. Oben an der einen Seite ein sehr kräftiges breites dreisneidiges Apicalhorn, fast zweimal so lang wie der Cephalis, an der andren Seite ein ähnliches, aber viel kleineres Horn, das nur $1 / 4$ so lang ist, auch gewöhnlich fehlt. Thorax kurz, breit conisch glockenförmig, mit grösseren, ziemlich dickwandigen Poren, die im unteren Theile grösser und mehr eckig werden. Abdomen kurz und weit glockenförmig mit sehr ungleichen und unregelmässigen Poren, die gegen den unteren Saum grösser und mehr dünnwandig werden. Der Mündungssaum uneben, von einer unvollständige Reihe grossen Poren, deren unteren Wände an vielen Stellen weggefallen sind, gebildet. (Dieses 
Exemplar daher wohl noch jung). Das Abdomen ist etwas unterhalb der Mitte mit starken, etwas gekrümmten, eckigen Nebenstacheln versehen, die etwa so lang wie die Breite des Cephalis sind. Unter diesen Stacheln sieht man an den meisten Porenecken ganz kurze ähnliche Stacheln oder pyramidale Erhebungen (die wahrscheinlich später zu ähnlichen Nebenstacheln wie die höher gestellten auswachsen).

Selten: Febr., Mai-Juni, Novbr.-Decbr.

Types. Not defined. See Remarks.

Remarks. In 1905 (p. 139), Jørgensen synonymized this species with Androcyclas gamphonycha. Based on our slide inspection we are convinced that Pterocorys gamphonyxos is a juvenile stage of A. gamphonycha. Androcyclas gamphonycha Jørgensen is regarded as the correct formal name.

Pterocorys theoconus Jørgensen, 1900

(Not illustrated - see Remarks)

1900 Pterocorys theoconus Jørgensen: 86 (not figured). 1905 Androcyclas gamphonycha Jørgensen: 139; pl. 17, figs 92-97.

\section{Original description (Jørgensen, 1900)}

Der obere Theil des Cephalis fast cylindrisch, wenig höher als breit, oben (wie gewöhnlich einseitig) mit einem kräftigen, dreischneidigen, 2 - 3-mal längeren Apicalhorn versehen, das unten fast so breit wie der Cephalis ist. Poren des Cephalis rundlich, sehr ungleich gross, am grössten in der Nähe der Hornbasis, dickwandig, 4 oder mehr auf dem Durchmesser. Unten geht der Cephalis in einen querrectangulären Halstheil über, der ungefähr zweimal so breit wie hoch und wenig breiter als der übrige Theil des Cephalis ist. Thorax breit kegelförmig mit ungleich grossen, rundlichen, länglichen und polygonalen Poren versehen, die nach unten viel grösser werden (weiter oben einige sehr kleine untermischt). Abdomen kurz und weit glockenförmig, nach unten zu fast gleichbreit. Der untere Rand sehr uneben, mit einer Reihe unentwickelter grosser Poren, deren Wände hie und da in kurze, breite Dorne verwandelt sind. Poren sehr ungleich gross, nach unten zu grösser und sehr dünn- (aber breit-) wandig. In dem Cephalis (mit dessen Halstheil) und dem oberen Theile des Thorax finden sich innere Skelettbalken, von denen einige (wahrscheinlich 4) als feine, nadelförmige, ziemlich kurze Radialstacheln die Schaale im oberen Theil des Thorax oder in der Halsregion durchbrechen. Keine Nebenstacheln. Höhe des Cephalis $0,036 \mathrm{~mm}$. (Hals $0,012 \mathrm{~mm}$. mitgerechnet), Breite oben 0,024, unten (in der Halsregion) 0,026, Höhe des Thorax 0,040, Breite unten 0,084, Höhe des Abdomen 0,050, Breite unten 0.114. Poren des Cephalis bis $0,006 \mathrm{~mm}$. breit, auf dem Abdomen bis 0,020.

Sehr selten, in tieferen Wasserschichten: Herløfjord, 25/4 und 10/5 1898. Das Abdomen war in verschiedenem Grade an den gefundenen Exemplaren entwickelt. Die Beschreibung entspricht ohne Zweifel einem noch nicht erwachsenen Individuum.

Types. Not defined.

Remarks. Jørgensen (1905, p. 139) synonymized this species with Androcyclas gamphonycha. A. gamphonycha Jørgensen is regarded as the correct formal name.

\section{Stichocorys seriata Jørgensen, 1905 (P1. 7, figs 10-16)}

1902 Eucyrtidium seriatum Jørgensen (in Gran, 1902): 150 (nomen nudum).

1905 Stichocorys seriata Jørgensen: 140; pl. 18, figs 102-104.

Original description (Jørgensen, 1905)

A many-jointed form. The uppermost joints are convex and increase in size so that the diameter of the fifth is from three to four times as great as that of the first. The lower part is more or less distinctly cylindrical. On the cephalis, there is a short broad tophorn. The pores below are roundish rectangular, in very distinct, regular, horizontal rows. The number of the joints varies, probably according to age. Uppermost there is a low, semispherical (or broader) cephalis, then short joints, which increase evenly in width up to the fourth or fifth, which is usually the broadest. From the sixth joint, which is decidedly narrower, the width decreases, but very slowly, so that the lower part is almost cylindrical, only a little narrower below. I have not seen more than eight joints. These lower joints in the cylindrical part are not plainly divided off from each other. The upper part of the shell is shaped like a high cone. There is a short, broad, threeedged (?) tophorn protruding from an inner skeleton in the two upper joints. It is not easy to see these inner skeleton parts which are, at all events, in a high degree retrograded, for it is a difficult matter to examine the shell from the open end, and the outer lattice shell in side view hides the short, primary spines. So I have not been able definitely to decide whether this genus has the same primary skeleton parts as the foregoing ones [Dictyoceras acanthicum, D. xiphephorum]. Neither have I been sure if protruding basal spines exist in the two upper joints (the apical spine only excepted). The shape of the cephalis in some positions of the lattice shell might suggest that also inner primary arches are to be found, and not only the primary spines. It is doubtful whether there is a protruding ventral, sagittal spine. On the other hand, a long, inner axial spine is plainly visible. It seems to consist of three or more long, parallel branches, which reach down through more than half the length of the lattice shell. The central capsule also reaches far down through the shell. The pores on the cephalis are small, round, widely apart and scattered. On the second joint, they are perhaps a little larger, on the third somewhat smaller again, and from here they are regularly placed in horizontal rows. From the fourth joint and downwards, the pores become more irregular in form and size, from quite small and round to rather large, roundish rectangular in shape, although generally speaking they are small and always in regular, horizontal rows. On the cylindrical lower part, they are also placed in more irregular vertical rows. The average size of the pores does not increase, at any rate noticeably, from the fourth joint downwards. This species varies rather considerably. For instance, its greatest width may be either in the fourth or fifth joint, and there are often irregular contractions in the lower part. It is doubtful whether any of the individuals illustrated are fully developed. On the best developed specimen (Jørgensen 1905, fig. 102) the lower margin was regularly dentate. Often young individuals may be found consisting of only a few joints and entirely without the cylindrical lower part. Height, up to $128 \mu$, greatest width $72 \mu$. Pores, up to $6 \mu$. The species resembles the one illustrated by Cleve (1899, pl. 2, figs 5-6), which he calls Lithomitra australis EHRB. It is probable that the same basal spines are present in this species, protruding as fine needles, as in Androcyclas gamphonycha and Clathrocyclas craspedota. Even if these spines are present, Haeckel's name for the genus might in this case be retained without any great disadvantage. Rather rare, always in small numbers and only in deep water samples. Distribution: In surface samples, 2/2 1901, off Søndmøre, 13/2 off Lofoten and 5/3 off Finmark. Most probably a boreal oceanic species.

Lectotype. PMO224.494/1; Plate 7, fig. 12; Slide \#25 (N38/0).

Paralectotype 1. PMO224.494/2; Plate 7, fig. 13; Slide \#25 (N38/0 middle).

Paralectotype 2. PMO224.495; Plate 7, fig. 14a, b; Slide \#66 (K39/2).

Paralectotype 3 and 4. PMO224.494/3 (left), PMO224.494/4 (right); Plate 7, fig. 15a, b; Slide \#25 (N38/0 middle).

Paralectotype 5. Plate 7, fig. 16a, b. Slide \# 68 (N36/3), PMO224.496.

Remarks. Jørgensen radiolarian slide \#25 has four specimens and he assigned these to the genus Eucyrtidium (see slide label). In a 
list in Gran (1902) the name Eucyrtidium seriatum (nomen nudum) was used. All radiolarian species lists/tables in the papers by Gran were prepared and provided by Jørgensen. Jørgensen (1905) formally described this species as Stichocorys seriata not Eucyrtidium seriatum as written on the slide and in Gran (1902). Stichocorys seriata Jørgensen is regarded as the correct formal name.

\section{CONCLUSION}

Jørgensen described, in his publications from 1900 and 1905, 43 new polycystine radiolarian species from the western and northern coast of Norway. Many of these are common cold-water species and are still frequently reported by radiolarian researchers. Most of Jørgensen's species descriptions were accompanied by his beautiful and detailed hand-made drawings; however, no type specimens were assigned. In an attempt to clarify and document Jørgensen's species concept we have re-examined his original slide collection. Our main attention was given to the radiolarian slides that had a Norwegian coast affinity (76 slides in total). The radiolarian specimens on these slides were sampled between 1887 and 1900 and most of them are in very good condition. During our work we were able to identify and designate lectotypes and paralectotypes for 28 of the 43 species described by Jørgensen. All types have been documented by images as well as England finder coordinates on the respective slides. For the remaining 15 species we were either not able to find them on Jørgensen's slides or we believe them to be juvenile forms or incomplete specimens of other species. One species that Jørgensen described we did not find in his collection (Lithomelissa laticeps). This species is common in the Norwegian fjords leading us to think that our collection of Jørgensen's slides might not be complete. However, we hope that this attempt to make Jørgensen's work more readily available will be of value to current and future radiolarian researchers.

\section{ACKNOWLEDGEMENTS}

We would very much like to thank the two reviewers of this paper. We gratefully acknowledge the thorough and very detailed review by Annika Sanfilippo. The feedback and useful suggestions from Demetrio Boltovskoy are also very much appreciated. Both reviews greatly improved our paper. We would also like to thank David Lazarus, John Gregory, Alan Lord and Sarah Gibbs for their kind help with checking and formatting the text. Acknowledgement is also made to Johanne Kjennerud, former Curator at Bergen Museum, who very kindly donated the Jørgensen radiolarian slide collection to KRB; slides that are now stored in the Type Collection of the Natural History Museum, University of Oslo.

\section{Manuscript received 11 December 2012 \\ Manuscript accepted 11 December 2012 \\ Scientific editing by F. John Gregory}

\section{REFERENCES}

Bailey, J.W. 1856. Notice of microscopic forms found in the soundings of the Sea of Kamtschatka. The American Journal of Science and Arts, Second series, 22: 1-6.

Bjørklund, K.R. 1976. Actinomma haysi, n. sp., its Holocene distribution and size variation in Atlantic Ocean sediments. Micropaleontology, 23: 114-126.

Bjørklund, K.R., Itaki, T. \& Dolven, J.K. 2014. Per Theodor Cleve: A short résumé and his radiolarian results from the Swedish Expedition to Spitsbergen in 1898. Journal of Micropalaeontology, 33, 59-93.
Bjørklund, K.R. \& Kruglikova, S.B. 2003. Polycystine radiolarians in surface sediments in the Arctic Ocean basins and marginal seas. Marine Micropaleontology, 49: 231-273.

Boltovskoy, D., Kling, S.A., Takahashi, K. \& Bjørklund, K.R. 2010. World atlas of distribution of Recent Polycystina (Radiolaria). Palaeontologia Electronica, 13: 230. http://palaeo-electronica.org/2010_3/215/index.html

Cleve, P.T. 1899. Plankton collected by the Swedish Expedition to Spitzbergen in 1898. Kongliga Svenska Vetenskaps Akademiens Handlingar, 32: 1-51.

Cleve, P.T. 1900. Notes on some Atlantic Plankton-organisms. Kongliga Svenska Vetenskaps Akademiens Handlingar, 34: 1-22.

Cortese, G. \& Bjørklund, K.R. 1998. Morphometry and taxonomy of Hexacontium species from western Norwegian fjords. Micropaleontology, 44: 161-172.

Dumitrica, P. 1973. Cretaceous and Quaternary Radiolaria in deep sea sediments from the Northwest Atlantic Ocean and Mediterranean Sea. In Ryan, W. et al. (Eds), Initial Reports of the Deep Sea Drilling Project. US Government Printing Office, Washington, DC, 13: 829-901.

Dumitrica, P. 2001. On the status of the radiolarian genera Gonosphaera Jørgensen and Excentroconcha Mast. Revue de Micropaléontologie, 44: 191-198.

Ehrenberg, C.G. 1872. Mikrogeologischen Studien über das kleinste Leben der Meeres-Tiefgründe aller Zonen und dessen geologischen Einfluss. Königlichen Akademie der Wissenschaften zu Berlin, Abhandlungen. Jahre 1872: 131-399.

Goll, R.M. 1976. Morphological intergradation between modern populations of Lophospyris and Phormospyris (Trissocyclidae, Radiolaria). Micropaleontology, 22: 379-418.

Goll, R.M. 1979. The Neogene evolution of Zygocircus, Neosemantis, and Callimitra: their bearing on nassellarian classification. A revision of Plagiacanthoidae. Micropaleontology, 25: 365-396.

Gran, H.H. 1902. Das plankton des Norwegischen Nordmeeres von biologischen und hydrographischen Gesichtspunkten behandelt. Report on Norwegian Fishery and Marine Investigations, 2: 1-231.

Haeckel, E. 1860. Fernere Abbildungen und Diagnosen neuer Gattungen und Arten von lebenden Radiolarien des Mittelmeeres [Supplementary illustrations and diagnosis of new genera and species of living radiolarian of the Mediterranean Sea]. Königliche Preussische Akademie der Wissenschaften zu Berlin, Monatsberichte. Jahre 1860: 835-845.

Haeckel, E. 1862. Die Radiolarien (Rhizopoda Radiaria) - Eine monographie. Reimer, Berlin, 572pp.

Haeckel, E. 1887. Report on the Radiolaria collected by the H.M.S. Challenger during the Years 1873-1876. Report on the Scientific Results of the Voyage of the H.M.S. Challenger, Zoology, 18: 1-1803.

Hollande, A. \& Enjumet, M. 1960. Cytologie, évolution et systématique des Sphaeroidés (Radiolaires). Archives du Muséum National d'Histoire Naturelle, Paris, 7: 1-134.

Itaki, T. \& Bjørklund, K.R. 2006. Bailey's 1856 radiolarian types from the Bering Sea re-examined. Micropaleontology, 52: 449-464.

Jørgensen, E.H. 1900. Protophyten und Protozöen im Plankton aus der norwegischen Westküste. Bergens Museums Aarbog [1899], 6: 51-112.

Jørgensen, E.H. 1905. The Protist plankton and the diatoms in bottom samples. VII. Radiolaria. In Nordgaard, O. (Ed.) Hydrographical and Biological Investigations in Norwegian Fjords. Bergens Museum Skrifter, Ser. 1, 7: 114-142.

Jørgensen, E.H. 1907. Note sur les Radiolaires. Croisiere Oceanographique Belgica, Mer du Gronland [1905], Bulens, C., Imprimerie Scientifique. Brussels, Belgium, 455-459.

Jørgensen, E.H. 1911. Die Ceratien. Eine kurze Monographie der Gattung Ceratium Schrank. Internationale Revue der Gesamten Hydrobiologie und Hydrographie, 4: 1-124.

Jørgensen, E.H. 1934. Norges levermoser. Bergens Museums Skrifter, 16: 1-343.

Kozur, H. \& Möstler, H. 1982. Entactinaria subordo Nov., a new radiolarian suborder. Geologisch-- Paläontologische Mitteilungen, Innsbruck, 11/12: 399-414. 
Nigrini, C. \& Moore, T.C. 1979. A guide to modern Radiolaria. Cushman Foundation for Foraminiferal Research, Special Publication, 16: 1-248.

Petrushevskaya, M.G. 1968. Radiolarians of Orders Spumellaria and Nassellaria of the Antarctic region. In Andriyashev, A.P. \& Ushakov, P.V. (Eds) Studies of Marine Fauna IV (XII), Biological Reports of the Soviet Antarctic Expedition (1955-1958), 3: 2-186. Israel Program for Scientific Translations, Jerusalem.

Petrushevskaya, M.G. 1971. Radiolyarii Nassellaria v planktone Mirovogo Okeana. Issledovaniya Fauny Morei. 9: 1-294 (+ App., pp. 374-397). Nauka, Leningrad [in Russian].
Popofsky, A. 1913. Die Nassellarien des Warmwassergebietes. In Drygalski, E. (Ed.) Deutsche Südpolar-Expedition 1901-1903. (Zoologie, 6), XIV: 217-416.

Schröder, O. 1914. Die nordischen Nassellarien. Nordisches Plankton (1929), 7: 67-146. Zoologischer Teil, Siebenter Band: Protozoa. Verlag von Lipsius \& Tischer, Kiel. Fig. 1. Eugen Honoratus Jørgensen (18621938). Fig. 2. (a, b) Jørgensen's 'apotek' at the University of Bergen. (c, d) Small bottles containing plankton samples collected during cruises off the western and northern coast of Norway 1897-1900. (e, f) Examples of Jørgensen's radiolarian slides (see also Pls 8-10). 